\title{
Heterogeneous ice nucleation on atmospheric aerosols: a review of results from laboratory experiments
}

\author{
C. Hoose and O. Möhler \\ Institute for Meteorology and Climate Research - Atmospheric Aerosol Research, Karlsruhe Institute of Technology, \\ Karlsruhe, Germany \\ Correspondence to: C. Hoose (corinna.hoose@ kit.edu)
}

Received: 9 April 2012 - Published in Atmos. Chem. Phys. Discuss.: 16 May 2012

Revised: 21 September 2012 - Accepted: 28 September 2012 - Published: 29 October 2012

\begin{abstract}
A small subset of the atmospheric aerosol population has the ability to induce ice formation at conditions under which ice would not form without them (heterogeneous ice nucleation). While no closed theoretical description of this process and the requirements for good ice nuclei is available, numerous studies have attempted to quantify the ice nucleation ability of different particles empirically in laboratory experiments. In this article, an overview of these results is provided. Ice nucleation "onset" conditions for various mineral dust, soot, biological, organic and ammonium sulfate particles are summarized. Typical temperaturesupersaturation regions can be identified for the "onset" of ice nucleation of these different particle types, but the various particle sizes and activated fractions reported in different studies have to be taken into account when comparing results obtained with different methodologies. When intercomparing only data obtained under the same conditions, it is found that dust mineralogy is not a consistent predictor of higher or lower ice nucleation ability. However, the broad majority of studies agrees on a reduction of deposition nucleation by various coatings on mineral dust. The ice nucleation active surface site (INAS) density is discussed as a simple and empirical normalized measure for ice nucleation activity. For most immersion and condensation freezing measurements on mineral dust, estimates of the temperature-dependent INAS density agree within about two orders of magnitude. For deposition nucleation on dust, the spread is significantly larger, but a general trend of increasing INAS densities with increasing supersaturation is found. For soot, the presently available results are divergent. Estimated average INAS densities are high for ice-nucleation active bacteria at high subzero temperatures. At the same time, it is shown that INAS densities
\end{abstract}

of some other biological aerosols, like certain pollen grains, fungal spores and diatoms, tend to be similar to those of dust. These particles may owe their high ice nucleation onsets to their large sizes. Surface-area-dependent parameterizations of heterogeneous ice nucleation are discussed. For immersion freezing on mineral dust, fitted INAS densities are available, but should not be used outside the temperature interval of the data they were based on. Classical nucleation theory, if employed with only one fitted contact angle, does not reproduce the observed temperature dependence for immersion nucleation, the temperature and supersaturation dependence for deposition nucleation, and the time dependence of ice nucleation. Formulations of classical nucleation theory with distributions of contact angles offer possibilities to overcome these weaknesses.

\section{Introduction}

Ice crystals in the atmosphere have important impacts on radiative transfer, precipitation formation, and the microphysical and optical properties of clouds. Therefore, their formation has been studied both in the field and under controlled conditions in laboratory experiments since many years (e.g., Dufour, 1861; Schaefer, 1949; Georgii and Kleinjung, 1967; DeMott et al., 2011). It is known that water droplets in the atmosphere do not freeze instantaneously at $0^{\circ} \mathrm{C}$. Their freezing can either be triggered by aerosol particles acting as a so-called ice nuclei (IN), or occur homogeneously (without IN) at about $-38^{\circ} \mathrm{C}$ (Pruppacher and Klett, 1997). The goal of many laboratory studies was and is to assess the ice nucleation ability of selected aerosol particles of a 


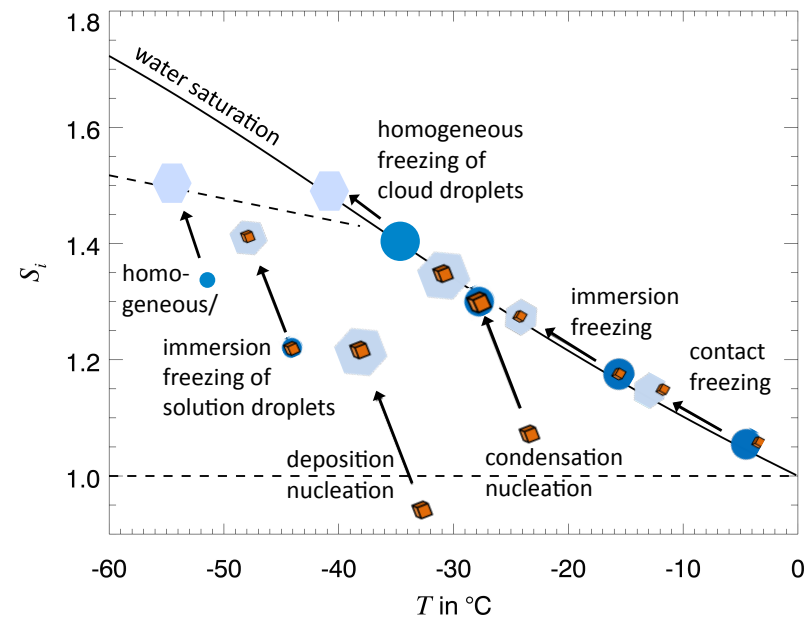

Fig. 1. Schematic representation of the different nucleation modes.

specific composition (e.g., Pruppacher and Saenger, 1955; Isono et al., 1959a). While earlier parameterizations of heterogeneous ice nucleation (Young, 1974; Meyers et al., 1992) did not include any aerosol-specific dependencies, the results of such experiments and their parametrical descriptions are nowadays frequently used in atmospheric models on different scales, from cloud resolving models to global climate models (e.g., Kärcher and Lohmann, 2003; Liu and Penner, 2005; Lohmann and Diehl, 2006; Grützun et al., 2008; Phillips et al., 2009; Eidhammer et al., 2010; Hoose et al., 2010a,b; Storelvmo et al., 2011), and enter the calculations of aerosol indirect effects in mixed-phase and cirrus clouds.

In this article, we will provide a summary and overview of historical and recent ice nucleation experiments. Results for a wide range of different aerosol types, sizes, obtained with different instruments and experimental boundary conditions are intercompared. In individual studies, where the focus is often on instrument development and/or process studies, such comparisons to results with other instruments are often selective or omitted, with the exception of a few coordinated instrument intercomparison exercises (Langer, 1973; DeMott et al., 2011). Here, we try to set the individual studies and their results into a larger context. The parameters which possibly influence results from different instruments will be discussed one for one, and consistent tendencies will be identified. In addition, we will discuss to what degree parametrical descriptions agree with these general features of the data. However, within this study, we will not attempt to provide quality classifications of methods or individual studies, or new unified parameterizations.

It is also an aim of this article to make the results of laboratory experiments more accessible to potential users within the modelling community. Furthermore, we will scrutinize some common assumptions in models, e.g. fixed thresholds for nucleation onset (e.g., Hendricks et al., 2011), the higher ice nucleation efficiency of certain mineral phases

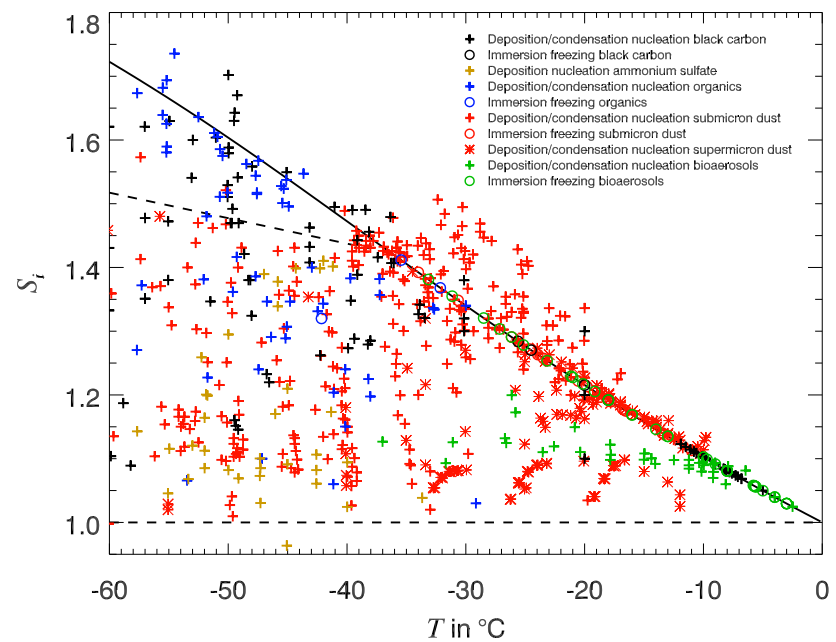

Fig. 2. Overview of ice nucleation onset temperatures and saturation ratios. Data sources are listed in the following figures.

(e.g., Lohmann and Diehl, 2006), the assignment of nucleation modes to certain temperature intervals (e.g., Ervens et al., 2011) and the applicability of classical nucleation theory (e.g., Khvorostyanov and Curry, 2005; Liu and Penner, 2005; Hoose et al., 2010b).

Finally, we will identify open questions and give recommendations for future studies.

\section{Onset conditions for heterogeneous ice nucleation}

Temperature $(T)$ and saturation ratio with respect to ice $\left(S_{\mathrm{i}}\right)$ are the main environmental factors which determine ice nucleation. Laboratory ice nucleation experiments aim at the determination of the aerosol-specific ice nucleation properties under controlled environmental conditions. Early results have often been reported as "onset" temperatures and saturation ratios, i.e. the highest temperatures and lowest saturation ratios for which a certain amount of ice formation is observed. This "onset" either corresponds to a detection limit or to a chosen activated fraction.

In both experiments and in the atmosphere, aerosols can experience a variety of different trajectories in the $T-S_{\mathrm{i}}$ space, as shown in Fig. 1. Most air parcels rising from the surface reach water saturation at temperatures above $-40^{\circ} \mathrm{C}$ (Wiacek and Peter, 2009), but often undergo oscillations and cycling through clouds before reaching the upper troposphere with temperatures below $-40^{\circ} \mathrm{C}$. Above $S_{\mathrm{i}}=1$, the dashed horizontal line in Fig. 1, ice is the stable phase. Supercooled liquid water is in equilibrium with the vapour phase along the solid diagonal line, which represents the ice saturation ratio at liquid water saturation. Concentrated solution droplets are in thermodynamic equilibrium at lower relative humidities with respect to water according to the water activity of the solutes. At temperatures below about $-38^{\circ} \mathrm{C}$, 
water and solution droplets freeze homogeneously. The homogeneous nucleation rate of solutes can be formulated as a function of the water activity $a_{\mathrm{w}}$ (Koop et al., 2000). In Fig. 1 and the following diagrams, the isoline for a homogeneous nucleation rate coefficient of $5 \times 10^{14} \mathrm{~m}^{-3} \mathrm{~s}^{-1}$ is indicated for reference.

Figure 2 summarizes ice nucleation onset data from a large number of studies with atmospherically relevant aerosol particles. The data shown here correspond not only to different particle species and nucleation modes, as indicated by the colors and symbols, but also to different experimental methods, particle sizes, sample preparation, activated fraction and more. This complicates the comparison of results from different studies, in some cases making it even impossible. Therefore we will focus in the following on relative and normalized efficiencies, expressed by different metrics, and search for recurring patterns and parametrical dependencies in different experiments.

In the following, the data shown in the overview plot of Fig. 2 will be analysed in more detail. In particular, the following factors are thought to be relevant for onset supersaturation/temperature of ice nucleation: the chemical composition (discussed in Sect. 3.1), for mineral dust its mineralogy (discussed in Sect. 3.2), coatings (discussed in Sect. 3.4), the activated fraction for which the "onset" is reported in conjunction with the particle surface area (discussed in Sect. 4.1), and time (discussed in Sect. 4.2). Before that, we will give a brief overview of atmospheric conditions which are relevant to heterogeneous ice nucleation.

\subsection{Typical ice nucleation onset in the atmosphere}

The ice nucleation onset conditions measured for different aerosol particles can be compared to typical ice onsets in the atmosphere. For mixed-phase clouds, a number of in-situ and remote sensing observations are available which quantified typical water to ice transition temperatures (Korolev et al., 2003; Field et al., 2004; Kanitz et al., 2011). These indicate that, depending on the measurement location, more than half of the clouds at temperatures lower than -15 to $-20^{\circ} \mathrm{C}$ contain ice, while at higher temperatures, clouds are more often purely liquid (within the detection limit of the instrument). These transition temperatures coincide with immersion freezing onset temperatures of some mineral dusts and biological particles. If seeding from upper levels can be excluded for the investigated cases, it can be inferred that such particles have to be present in the atmosphere to explain the observed cloud phase distribution. This inference is supported by a shift of the liquid-to-ice-transition to higher temperatures for dusty conditions (Seifert et al., 2010).

For cirrus clouds, the frequency of occurrence of icesupersaturations (Haag et al., 2003; Krämer et al., 2009) gives some indications on the availability of IN. Both in clear air and in cirrus clouds, ice saturation ratios up to about $130 \%$ are not uncommon, which lets us presume that par- ticles nucleating ice at lower saturation ratios (e.g., large mineral dusts or specific crystalline organic acids) are not ubiquitous in the upper troposphere. However, as supersaturations can persist in the presence of crystals due to sustained cooling or suppressed growth (Peter et al., 2006), no further conclusions can be drawn about the maximum or minimum efficiency of IN required to explain the observed humidity distribution (Spichtinger and Gierens, 2009).

\section{Qualitative influence of composition on ice nucleation properties}

\subsection{Main groups of atmospherically relevant IN}

IN are generally solid, water-insoluble particles (Pruppacher and Klett, 1997). The crystallographic structure of surfaces seems to have some influence on their ice nucleation abilities (Mason, 1971). In addition, so-called active sites, i.e. localized topographic features like cracks or chemical impurities, can determine a particle's ice nucleation behaviour (Pruppacher and Klett, 1997). However, so far, predictions of a material's ice nucleation ability based on its chemical or physical properties are impossible. The following sections provide an overview of the ice nucleation abilities of mineral dust particles, soot, bioaerosols (bacteria, fungal spores, pollen and diatoms), solid ammonium sulfate, organic acids and humic-like substances. Nucleation onset conditions from numerous experiments are shown separately for these particle types in Figs. 3-5. Details about the data sources are listed in Tables 1-6. It should be noted that these "onset" data cover a wide range of ice-active particles fractions, as indicated in Tables 1-5 wherever available. The experiments are conducted with many different instruments and experimental setups, which are listed in Table A2. For details about instrumentation and measurement principles, we refer the reader to the original works and to the overviews given by DeMott (2002) and DeMott et al. (2011).

\subsubsection{Mineral dust}

Because of the large number of experiments with mineral dust, these are separated into four graphs (Fig. 3), Fig. 3a, b including only results with mainly submicron particles (either monodisperse or size distributions with a mode diameter smaller than $1 \mu \mathrm{m}$ ) and Fig. 3c, d including experiments with larger particles. More detailed size specifications for the mineral dust samples are given in Table 1. Comparing Fig. 3a, b with $\mathrm{c}, \mathrm{d}$, it is obvious that larger particles tend to nucleate ice at lower supersaturations and higher temperatures. The data are color-coded with respect to the mineralogical composition of the samples. Black symbols represent natural desert dust samples collected in different regions of the world. Green symbols represent Arizona test dust (ATD), a commercial product of milled soil dust available from Powder Technology, Inc. Blue, red and yellow symbols represent 
Table 1. Laboratory experiments with mineral dust particles.

\begin{tabular}{|c|c|c|c|c|c|c|c|}
\hline Reference & material & $\begin{array}{l}\text { type of in- } \\
\text { strument }\end{array}$ & $\begin{array}{l}\text { name of instru- } \\
\text { ment or } \\
\text { institution }\end{array}$ & nucleation mode & size & activated fraction & $\begin{array}{l}\text { residence time/ } \\
\text { cooling rate }\end{array}$ \\
\hline Archuleta et al. (2005) & Asian dust & CFDC-C & CSU & $\begin{array}{l}\text { deposition and } \\
\text { condensation }\end{array}$ & 50,100 and $200 \mathrm{~nm}$ & $1 \%$ & 10 to $13 \mathrm{~s}$ \\
\hline Bailey and Hallett (2002) & kaolinite & $\begin{array}{l}\text { TGDC/ } \\
\text { CECC }\end{array}$ & DRI & $\begin{array}{l}\text { deposition and } \\
\text { condensation }\end{array}$ & 5 to $10 \mu \mathrm{m}$ and smaller & $<\approx 0.1 \%$ & $200 \mathrm{sK}^{-1}$ \\
\hline Broadley et al. (2012) & illite & $\mathrm{CS}$ & ULeeds & immersion & $\begin{array}{l}\text { specific surface area } \\
\text { given }\end{array}$ & 0 to $100 \%$ (spectra) & 6 to $75 \mathrm{~s} \mathrm{~K}^{-1}$ \\
\hline Bundke et al. (2008) & ATD, kaolinite & CFMC & FINCH & $\begin{array}{l}\text { deposition and } \\
\text { condensation }\end{array}$ & n.a. & $\begin{array}{l}\text { relative to } \\
\text { maximum value }\end{array}$ & $4.5 \mathrm{~s}$ \\
\hline Bundke et al. (2008) & kaolinite, illite & ISDC & FRIDGE & $\begin{array}{l}\text { deposition and } \\
\text { condensation }\end{array}$ & n.a. & $\begin{array}{l}\text { relative to } \\
\text { maximum value }\end{array}$ & $\approx 90 \mathrm{~s}$ \\
\hline Bunker et al. (2012) & ATD, kaolinite & CS & $\begin{array}{l}\text { Michigan Tech- } \\
\text { nological U }\end{array}$ & contact & 62.5 to $1000 \mathrm{~nm}$ & $10^{-8}$ to $10^{-3}$ & n.a. \\
\hline Chernoff and Bertram (2010) & $\begin{array}{l}\text { kaolinite, illite, } \\
\text { montmorillonite, quartz }\end{array}$ & CS-FDC & UBC & $\begin{array}{l}\text { deposition and } \\
\text { condensation }\end{array}$ & $\begin{array}{l}\text { mean diameters: } \\
5.8 \text { to } 10.3 \mu \mathrm{m}\end{array}$ & $0.1 \%$ to $1 \%$ & $600 \mathrm{sK}^{-1}$ \\
\hline Connolly et al. (2009) & $\begin{array}{l}\text { ATD, Asian } \\
\text { dust, Saharan } \\
\text { dust }\end{array}$ & CECC & AIDA & $\begin{array}{l}\text { deposition and } \\
\text { immersion }\end{array}$ & $\begin{array}{l}\text { mode diameters: } \\
0.3 \text { to } 0.5 \mu \mathrm{m}\end{array}$ & INAS density & 20 to $60 \mathrm{~s} \mathrm{~K}^{-1}$ \\
\hline Conen et al. (2011) & $\begin{array}{l}\text { montmorillonite and } 3 \\
\text { soil dusts from Europe } \\
\text { and Asia }\end{array}$ & DFA & UBasel & immersion & $<15 \mu \mathrm{m}$ & $\begin{array}{l}\text { n.a. (IN per } \\
\text { dust mass given) }\end{array}$ & $180 \mathrm{sK}^{-1}$ \\
\hline Cziczo et al. (2009a) & ATD and illite & CECC & AIDA & $\begin{array}{l}\text { deposition and } \\
\text { immersion }\end{array}$ & $<1 \mu \mathrm{m}$ & $1 \%$ & $\begin{array}{l}\text { corresponding to a } \\
\text { vertical velocity of } \\
\text { about } 0.1 \text { to } 2 \mathrm{~m} \mathrm{~s}^{-1}\end{array}$ \\
\hline Cziczo et al. (2009b) & $\begin{array}{l}\text { kaolinite, } \\
\text { undoped and } \\
\text { doped with lead }\end{array}$ & CFDC-P & ZINC & deposition & $200 \mathrm{~nm}$ & n.a. & 10 to $30 \mathrm{~s}$ \\
\hline Dymarska et al. (2006) & kaolinite & CS-FDC & UBC & $\begin{array}{l}\text { deposition and } \\
\text { condensation }\end{array}$ & $\begin{array}{l}\text { majority between } \\
1 \text { and } 20 \mu \mathrm{m}\end{array}$ & $\approx 0.1 \%$ to $0.5 \%$ & $600 \mathrm{sK}^{-1}$ \\
\hline Eastwood et al. (2008) & $\begin{array}{l}\text { kaolinite, montmoril- } \\
\text { lonite, quartz, calcite, } \\
\text { muscovite }\end{array}$ & CS-FDC & UBC & $\begin{array}{l}\text { deposition and } \\
\text { condensation }\end{array}$ & $\begin{array}{l}\text { mostly } 1 \text { to } 20 \mu \mathrm{m} \text {, mean sizes } \\
7.7 \text { to } 14.2 \mu \mathrm{m}\end{array}$ & $0.1 \%$ to $1 \%$ & $10 \mathrm{~s}$ (1 to $20 \mathrm{~s})$ \\
\hline Field et al. (2006) & $\begin{array}{l}\text { Asian and } \\
\text { Saharan dust }\end{array}$ & CECC & AIDA & $\begin{array}{l}\text { deposition and } \\
\text { condensation }\end{array}$ & mode diameter: $0.4 \mu \mathrm{m}$ & $0.5 \%$ and $8 \%$ & 20 to $60 \mathrm{sK}^{-1}$ \\
\hline Friedman et al. (2011) & kaolinite & CFDC-P & PNNL-CIC & $\begin{array}{l}\text { deposition and } \\
\text { condensation }\end{array}$ & 100,200 and $400 \mathrm{~nm}$ & $1 \%$ & $12 \mathrm{~s}$ \\
\hline Hoffer (1961) & $\begin{array}{l}\text { kaolinite, montmoril- } \\
\text { lonite, illite, halloysite }\end{array}$ & EDF & UChicago & immersion & n.a. & n.a. & $60 \mathrm{sK}^{-1}$ \\
\hline Hoyle et al. (2011) & ATD & CFDC-P & IMCA/ZINC & immersion & $800 \mathrm{~nm}$ & 0 to $100 \%$ (spectra) & $12 \mathrm{~s}$ \\
\hline Hung et al. (2003) & $\begin{array}{l}\text { hematite and } \\
\text { corundum }\end{array}$ & AFT & Harvard & immersion & 50 to $250 \mathrm{~nm}$ & $10^{-6}$ & $60 \mathrm{~s}$ \\
\hline Iraci et al. (2010) & $\begin{array}{l}\text { ATD and clay } \\
\text { sample } \\
\text { collected in } \\
\text { Sedona } \\
\text { (Arizona) }\end{array}$ & CS-SDC & NASA Ames & deposition & $\begin{array}{l}\text { ATD volume mean: } 5 \mu \mathrm{m} \text {, } \\
\text { ATD number median: } \\
1.2 \mu \mathrm{m}, \text { Sedona clay } \\
\text { number median: } 1.4 \mu \mathrm{m}\end{array}$ & n.a. & n.a. \\
\hline Isono and Ibeke (1960) & $\begin{array}{l}\text { Japanese sand, Chinese } \\
\text { loess, kaolinite, quartz } \\
\text { and fifteen other miner- } \\
\text { als }\end{array}$ & $\mathrm{CC}$ & $\begin{array}{l}\text { Bigg IN } \\
\text { counter, } \\
\text { UTokyo }\end{array}$ & n.a. & $\begin{array}{l}<30 \mu \mathrm{m}, \text { most } \\
\text { particles }<5 \mu \mathrm{m}\end{array}$ & $10^{-6}$ to $10^{-3}$ & n.a. \\
\hline Isono et al. (1959a) & quartz, loess & $\mathrm{CC}$ & $\begin{array}{l}\text { Bigg IN } \\
\text { counter, } \\
\text { UTokyo }\end{array}$ & n.a. & 1 to $10 \mu \mathrm{m}$ & $10^{-6}$ to $10^{-3}$ & n.a. \\
\hline Isono et al. (1959b) & quartz & $\mathrm{CC}$ & $\begin{array}{l}\text { Bigg IN } \\
\text { counter, } \\
\text { UTokyo }\end{array}$ & n.a. & n.a. & n.a. & n.a. \\
\hline Jones et al. (2011) & $\begin{array}{l}\text { ATD, Saharan } \\
\text { dust }\end{array}$ & CFDC-C & $\begin{array}{l}\text { CSU and } \\
\text { MINC }\end{array}$ & $\begin{array}{l}\text { deposition/ } \\
\text { condensation }\end{array}$ & mostly $<1 \mu \mathrm{m}$ & spectra; $0.1 \%$ & $\approx 10 \mathrm{~s}$ \\
\hline Kanji and Abbatt (2006) & $\begin{array}{l}\text { Saharan dust, } \\
\text { montmorillonite, silica, } \\
\text { alumina }\end{array}$ & CS-FDC & UToronto & $\begin{array}{l}\text { deposition and } \\
\text { condensation }\end{array}$ & 0.5 to $5 \mu \mathrm{m}$ & $\approx 10^{-4}$ & $\begin{array}{l}6 \mathrm{~s} \text { per } 1 \% \\
\text { change in } \mathrm{RH}_{\mathrm{i}}\end{array}$ \\
\hline Kanji et al. (2008) & $\begin{array}{l}\text { ATD, Saharan } \\
\text { dust, kaolinite, } \\
\text { montmorillonite, silica }\end{array}$ & CS-FDC & UToronto & $\begin{array}{l}\text { deposition and } \\
\text { condensation }\end{array}$ & $\begin{array}{l}\text { ATD: } 0-5 \mu \mathrm{m} \text {, silica: } \\
1.5 \mu \mathrm{m} \text {, others n.a., } \\
\text { surface area determined }\end{array}$ & $\geq 10^{-5}$ & $\begin{array}{l}\text { 6s per } 1 \% \\
\text { change in } \mathrm{RH}_{\mathrm{i}}\end{array}$ \\
\hline
\end{tabular}


Table 1. Continued.

\begin{tabular}{|c|c|c|c|c|c|c|c|}
\hline Reference & material & $\begin{array}{l}\text { type of in- } \\
\text { strument }\end{array}$ & $\begin{array}{l}\text { name of instru- } \\
\text { ment or } \\
\text { institution }\end{array}$ & nucleation mode & size & activated fraction & $\begin{array}{l}\text { residence time/ } \\
\text { cooling rate }\end{array}$ \\
\hline Kanji and Abbatt (2010) & ATD & CFDC-P & UToronto & $\begin{array}{l}\text { deposition and } \\
\text { condensation }\end{array}$ & $40,100,240 \mathrm{~nm}$ & $\begin{array}{l}0.1 \%, 1 \%, \\
\text { INAS densities }\end{array}$ & 9 to $11 \mathrm{~s}$ \\
\hline Kanji et al. (2011) & $\begin{array}{l}\text { ATD, Saharan, } \\
\text { Canary Island } \\
\text { and Israel dust }\end{array}$ & CFDC-P & UToronto & $\begin{array}{l}\text { deposition and } \\
\text { condensation }\end{array}$ & $\begin{array}{l}\text { size ranges between } 0.02 \\
\text { and } 3 \mu \mathrm{m} \text {, number modes be- } \\
\text { tween } 0.15 \text { and } 0.3 \mu \mathrm{m}\end{array}$ & $0.1 \%$ & 9 to $11 \mathrm{~s}$ \\
\hline Knopf and Koop (2006) & ATD & CS-SDC & ETHZ & $\begin{array}{l}\text { deposition and } \\
\text { condensation }\end{array}$ & 0.7 to $10 \mu \mathrm{m}$ & $5 \%$ & $\begin{array}{l}3-30 \text { s per } 1 \% \\
\text { change in } \mathrm{RH}_{\mathrm{i}}\end{array}$ \\
\hline Knopf et al. (2010) & kaolinite & CS-FDC & $\begin{array}{l}\text { Stony } \\
\text { Brook U }\end{array}$ & deposition & mean size 4.1 to $5.0 \mu \mathrm{m}$ & $0.02 \%$ to $0.8 \%$ & $600 \mathrm{sK}^{-1}$ \\
\hline Koehler et al. (2007) & $\begin{array}{l}\text { Owens lake } \\
\text { dust }\end{array}$ & CFDC-C & CSU & $\begin{array}{l}\text { deposition and } \\
\text { condensation }\end{array}$ & $100,200,300$ and $400 \mathrm{~nm}$ & $\begin{array}{l}1 \% \text { (aircraft unit), } 5 \% \\
\text { (laboratory } \\
\text { unit) }\end{array}$ & $\begin{array}{l}4 \mathrm{~s} \text { (aircraft unit) } \\
\text { and } 11 \mathrm{~s} \text { (laboratory } \\
\text { unit) }\end{array}$ \\
\hline Koehler et al. (2010) & $\begin{array}{l}\text { ATD, Saharan } \\
\text { and Canary Island dust }\end{array}$ & CFDC-C & CSU & $\begin{array}{l}\text { deposition and } \\
\text { condensation }\end{array}$ & 200,300 and $400 \mathrm{~nm}$ & $\begin{array}{l}1 \% \text { (ATD), } \\
5 \% \text { (others) }\end{array}$ & $\begin{array}{l}4 \mathrm{~s} \text { (aircraft unit) } \\
\text { and } 11 \mathrm{~s} \text { (laboratory } \\
\text { unit) }\end{array}$ \\
\hline Koop and Zobrist (2009) & ATD & DSC & $\begin{array}{l}\text { UBielefeld/ } \\
\text { ETHZ }\end{array}$ & immersion & $\begin{array}{l}\text { median diameter: } \\
0.35 \mu \mathrm{m}\end{array}$ & n.a. & $6 \mathrm{sK}^{-1}$ \\
\hline Kulkarni et al. (2009) & $\begin{array}{l}\text { Saharan dust } \\
\text { (Nigeria) }\end{array}$ & TGDC & ULeeds & deposition & $<38 \mu \mathrm{m}$ & $\approx 1 / 8$ & $60 \mathrm{~s}$ \\
\hline Kulkarni and Dobbie (2010) & $\begin{array}{l}\text { Spain, Dakar } \\
\text { and Nigeria } \\
\text { dust }\end{array}$ & TGDC & ULeeds & $\begin{array}{l}\text { deposition and } \\
\text { condensation }\end{array}$ & $<38 \mu \mathrm{m}$ & $\approx 1 / 10$ & $\approx 40$ to $550 \mathrm{~s}$ \\
\hline Kulkarni et al. (2012) & $\begin{array}{l}\text { ATD and } \\
\text { kaolinite }\end{array}$ & CFDC-P & PNNL-CIC & deposition & $100,300,400$ and $500 \mathrm{~nm}$ & $10^{-4}$ to $10^{-1}$ & n. a. \\
\hline Ladino et al. (2011) & kaolinite & FDNC & CLINCH & contact & 400 and $800 \mathrm{~nm}$ & spectra & n.a. \\
\hline Lüönd et al. (2010) & kaolinite & CFDC-P & IMCA & immersion & 200,400 and $800 \mathrm{~nm}$ & 0 to $100 \%$ (spectra) & $14 \mathrm{~s}$ \\
\hline Mangold et al. (2005) & ATD & CECC & AIDA & deposition & $\begin{array}{l}0.1 \text { to } 1.5 \mu \mathrm{m} \text {, count median di- } \\
\text { ameter } \approx 0.5 \mu \mathrm{m}\end{array}$ & $\begin{array}{l}\text { n.a. for onset, } \\
\text { maximum value: } \\
97 \%\end{array}$ & 20 to $45 \mathrm{~s} \mathrm{~K}^{-1}$ \\
\hline Marcolli et al. (2007) & ATD & DSC & ETHZ & immersion & $\begin{array}{l}\text { fine ATD: nominal } \\
0-3 \mu \mathrm{m}, \text { coarse ATD: } \\
\text { nominal } 0-7 \mu \mathrm{m} \text {, size } \\
\text { distributions measured }\end{array}$ & n.a. & $60 \mathrm{sK}^{-1}$ \\
\hline Mason and Maybank (1958) & $\begin{array}{l}\text { kaolinite, montmoril- } \\
\text { lonite, and } 28 \text { more }\end{array}$ & DMCC & $\begin{array}{l}\text { Imperial } \\
\text { College }\end{array}$ & $\begin{array}{l}\text { deposition, } \\
\text { condensation and } \\
\text { contact? }\end{array}$ & $\begin{array}{l}\text { ground material, submicron and } \\
\text { supermicron }\end{array}$ & $\approx 0.01 \%$ & $120 \mathrm{~s}$ \\
\hline Mason (1960) & $\begin{array}{l}\text { kaolinite, montmoril- } \\
\text { lonite, illite and seven } \\
\text { more }\end{array}$ & DMCC & $\begin{array}{l}\text { Imperial } \\
\text { College }\end{array}$ & $\begin{array}{l}\text { deposition, } \\
\text { condensation and } \\
\text { contact? }\end{array}$ & $\begin{array}{l}\text { ground material, large } \\
\text { submicron number } \\
\text { fraction }\end{array}$ & $\approx 0.01 \%$ & $120 \mathrm{~s}$ \\
\hline Möhler et al. (2006) & $\begin{array}{l}\text { ATD, Asian and Saha- } \\
\text { ran dust }\end{array}$ & CECC & AIDA & $\begin{array}{l}\text { deposition and } \\
\text { condensation }\end{array}$ & $\begin{array}{l}\text { median: } 350-400 \mathrm{~nm} \text {, } \\
\text { specific surface area } \\
\text { given }\end{array}$ & onset, $8 \%$ & $\begin{array}{l}\geq 15 \mathrm{sK}^{-1}, \mathrm{~d} S_{\mathrm{i}} / \mathrm{d} t \\
\text { available }\end{array}$ \\
\hline Murray et al. (2010) & $\begin{array}{l}\text { kaolinite, montmoril- } \\
\text { lonite }\end{array}$ & CS & ULeeds & immersion & $\begin{array}{l}\text { specific surface area } \\
\text { given }\end{array}$ & 0 to $100 \%$ & $6 \mathrm{sK}^{-1}$ \\
\hline Murray et al. (2011) & kaolinite & CS & ULeeds & immersion & $\begin{array}{l}\text { specific surface area } \\
\text { given }\end{array}$ & 0 to $100 \%$ & 6 to $75 \mathrm{~s} \mathrm{~K}^{-1}$ \\
\hline Niedermeier et al. (2010) & ATD & LFT & LACIS & immersion & $\begin{array}{l}300 \mathrm{~nm} \text {, INAS density } \\
\text { given }\end{array}$ & $\begin{array}{l}<0.1 \% \\
\text { (spectra) }\end{array} \quad$ to $100 \%$ & $1.6 \mathrm{~s}$ \\
\hline Niedermeier et al. (2011a) & ATD & LFT & LACIS & immersion & $300 \mathrm{~nm}$ & $\begin{array}{l}<0.1 \% \\
\text { (spectra) }\end{array} \quad$ to $100 \%$ & $1.6 \mathrm{~s}$ \\
\hline Niemand et al. (2012) & $\begin{array}{l}\text { ATD, Asian, } \\
\text { Saharan, } \\
\text { Canary Island } \\
\text { and Israel dust }\end{array}$ & CECC & AIDA & immersion & $\begin{array}{l}\text { number median } \\
d=0.2 \text { to } 1 \mu \mathrm{m}\end{array}$ & $10^{-5}$ to $10^{-2}$ & n.a. \\
\hline Pinti et al. (2012) & $\begin{array}{l}\text { kaolinite, montmoril- } \\
\text { lonite, illite and } \\
\text { Saharan dust }\end{array}$ & DSC & ETHZ & immersion & $\begin{array}{l}\text { number mode } \\
0.29 \text { to } 0.45 \mu \mathrm{m}\end{array}$ & n.a. & n.a. \\
\hline Pitter and Pruppacher (1973) & $\begin{array}{l}\text { kaolinite, montmoril- } \\
\text { lonite }\end{array}$ & VWT & UCLA & $\begin{array}{l}\text { immersion and } \\
\text { contact }\end{array}$ & $\begin{array}{l}d=0.1 \text { to } 30 \mu \mathrm{m} \text {, mode } \\
\text { between } 1 \text { and } 2 \mu \mathrm{m}\end{array}$ & n.a. & n.a. \\
\hline $\begin{array}{l}\text { Pruppacher and Saenger } \\
\text { (1955) }\end{array}$ & $\begin{array}{l}\text { clay, olivine, } \\
\text { tremolite, quartz, } \\
\text { diatomite, and } \\
\text { others }\end{array}$ & $\mathrm{CC}$ & ETHZ & unknown & 0.5 to $2 \mu \mathrm{m}$ & n.a. & $\approx 5$ to $30 \mathrm{~s}$ \\
\hline Roberts and Hallett (1968) & $\begin{array}{l}\text { kaolinite, montmoril- } \\
\text { lonite, calcite, gypsum, } \\
\text { biotite mica }\end{array}$ & CS-SDC & $\begin{array}{l}\text { Imperial } \\
\text { College }\end{array}$ & condensation & 0.5 to $3 \mu \mathrm{m}$ & $\begin{array}{l}0.01 \% \text { to } 100 \% \\
\text { (spectra) }\end{array}$ & n.a. \\
\hline Salam et al. (2006) & $\begin{array}{l}\text { kaolinite, montmoril- } \\
\text { lonite }\end{array}$ & CFDC-C & UDalhousie & $\begin{array}{l}\text { deposition and } \\
\text { condensation }\end{array}$ & $<0.5$ to $\approx 5 \mu \mathrm{m}$ & n.a. & 20 to $30 \mathrm{~s}$ \\
\hline
\end{tabular}


Table 1. Continued.

\begin{tabular}{|c|c|c|c|c|c|c|c|}
\hline Reference & material & $\begin{array}{l}\text { type of in- } \\
\text { strument }\end{array}$ & $\begin{array}{l}\text { name of instru- } \\
\text { ment or } \\
\text { institution }\end{array}$ & nucleation mode & size & activated fraction & $\begin{array}{l}\text { residence time/ } \\
\text { cooling rate }\end{array}$ \\
\hline Schaefer (1949) & $\begin{array}{l}\text { various soil, } \\
\text { loam and clay } \\
\text { samples }\end{array}$ & $\mathrm{CC}$ & $\begin{array}{l}\text { General } \\
\text { Electrics }\end{array}$ & n.a. & n.a. & n.a. & n.a. \\
\hline Schaller and Fukuta (1979) & $\begin{array}{l}\text { kaolinite, local } \\
\text { soil }\end{array}$ & $\begin{array}{l}\text { wedge- } \\
\text { shaped } \\
\text { TGDC }\end{array}$ & UDenver & $\begin{array}{l}\text { deposition and } \\
\text { condensation }\end{array}$ & n.a. & $1.3 \%$ & $60 \mathrm{~s}$ \\
\hline Sullivan et al. (2010a) & ATD & CFDC-C & CSU & $\begin{array}{l}\text { deposition and } \\
\text { condensation }\end{array}$ & $200 \mathrm{~nm}$ & $10^{-5}$ to 1 (spectra) & n.a. \\
\hline Svensson et al. (2009) & kaolinite & EDBC & UGothenburg & contact & 0.2 to $5 \mu \mathrm{m}$ & 0 to $>100 \%$ & n.a. \\
\hline Vali (2008) & $\begin{array}{l}\text { surface soil from Al- } \\
\text { berta, Canada, contain- } \\
\text { ing vegetative material }\end{array}$ & $\mathrm{CS}$ & UWyoming & immersion & n.a. & n.a. & $60 \mathrm{~s} \mathrm{~K}^{-1}$ \\
\hline Wang and Knopf (2011) & kaolinite & CS-FDC & $\begin{array}{l}\text { Stony } \\
\text { Brook U }\end{array}$ & deposition & mean size 2.3 to $4.3 \mu \mathrm{m}$ & $0.01 \%$ to $0.3 \%$ & $\begin{array}{l}60 \mathrm{~s} \text { per } 2.3 \% \text { to } \\
1.5 \% \text { change in } \\
\mathrm{RH}_{\mathrm{i}}, 12 \mathrm{~s} \text { between } \\
\text { subsequent obser- } \\
\text { vations }\end{array}$ \\
\hline Welti et al. (2009) & $\begin{array}{l}\text { ATD, kaolinite, } \\
\text { montmorillonite, } \\
\text { illite }\end{array}$ & CFDC-P & ZINC & $\begin{array}{l}\text { deposition and } \\
\text { condensation }\end{array}$ & $100,200,400$ and $800 \mathrm{~nm}$ & $1 \%$ & $12 \mathrm{~s}$ \\
\hline Wheeler and Bertram (2012) & kaolinite, illite & CS-FDC & UBC & deposition & $\begin{array}{l}\text { average diameters: } \\
\text { kaolinite } 8 \mu \mathrm{m} \text {, illite } 11 \mu \mathrm{m}\end{array}$ & $1 \%$ & $\begin{array}{l}600 \mathrm{sK}^{-1}, 60 \mathrm{~s} \\
\text { per } 1 \% \text { change in } \\
\mathrm{RH}_{\mathrm{i}}\end{array}$ \\
\hline Zimmermann et al. (2008) & $\begin{array}{l}\text { kaolinite, montmoril- } \\
\text { lonite, illite and } \\
6 \text { more }\end{array}$ & ESEM & UDarmstadt & $\begin{array}{l}\text { deposition (and } \\
\text { condensation) }\end{array}$ & 1 to $100 \mu \mathrm{m}$ & $\begin{array}{l}\approx 1 \% \text { and } \\
2-3 \%\end{array}$ & n.a. \\
\hline
\end{tabular}

kaolinite, montmorillonite, and illite, respectively, which are common clay minerals. For submicron particles, there seems to be a tendency of natural desert dusts to require the highest ice-supersaturations for activation, i.e. to be worse IN than kaolinite, montmorillonite and ATD in the deposition nucleation mode. This will be further investigated below. Otherwise, it is remarkable that the observations of ice nucleation on dust span the full range of water-subsaturated and watersaturated conditions below $-10^{\circ} \mathrm{C}$. Some data are also reported at significantly water-supersaturated conditions (e.g., Koehler et al., 2010). This may be due to kinetic limitations and humidity inhomogeneities within the continuous flow diffusion chamber (CFDC) instrument (Petters et al., 2009; DeMott et al., 2011).

\subsubsection{Soot}

For soot, fewer experiments are available, and those available show little overlap in the reported ice nucleation onset conditions (Fig. 4a and Table 2). In addition to these results, it should be noted that several studies report negative results (no ice nucleation within the instrument's detection limit) under certain investigated conditions. These are presented in Fig. 4 b: at $-40^{\circ} \mathrm{C}$, Kanji and Abbatt (2006) observed onset relative humidities for deposition ice nucleation in experiments with $\mathrm{n}$-hexane soot deposited on a substrate, which were not statistically different from those for the blank substrate. Dymarska et al. (2006) observed droplet formation before ice formation (occurring also on the bare substrate) for almost all experiments at temperatures between -15 and $-30^{\circ} \mathrm{C}$; Friedman et al. (2011) did not observe ice formation below water saturation for temperatures of -20 and $-30^{\circ} \mathrm{C}$, and only droplet formation above water saturation. Furthermore, at $-40^{\circ} \mathrm{C}$, only homogeneous freezing was observed, similar to Koehler et al. (2009) (also at $-40^{\circ} \mathrm{C}$ ). The negative results are in disagreement with a number of experiments (DeMott, 1990; Diehl and Mitra, 1998; Gorbunov et al., 2001; Popovicheva et al., 2008; Kireeva et al., 2009; Fornea et al., 2009) which observed ice nucleation on soot particles already at temperatures above $-30^{\circ} \mathrm{C}$. However, the latter were conducted in other nucleation modes (see Table 2) and partly with large particles or unknown particle concentrations per droplet (see also the discussion in Kärcher et al., 2007).

Also soot particles vary in composition, e.g. with respect to their organic carbon content, depending on the combustible and the combustion technique. Möhler et al. (2005b) and Crawford et al. (2011) found a significant decrease in ice nucleation activity with increasing organic carbon content at temperatures around $-65^{\circ} \mathrm{C}$ and $-47^{\circ} \mathrm{C}$, respectively. However, no systematic trends related to the soot type are seen from the experiments at higher temperatures. Despite the large spread in the results, it can be confirmed from this qualitative overview that soot is a generally worse ice nucleus than mineral dust, nucleating at higher ice-supersaturations for deposition nucleation and at lower temperatures for immersion freezing.

\subsubsection{Primary biological aerosol particles}

Figures $5 \mathrm{a}$ and $5 \mathrm{~b}$ display selected ice nucleation results for potentially airborne primary biological particles. Among 
Table 2. Laboratory experiments with soot particles.

\begin{tabular}{|c|c|c|c|c|c|c|c|}
\hline Reference & material & $\begin{array}{l}\text { type of in- } \\
\text { strument }\end{array}$ & $\begin{array}{l}\text { name of instru- } \\
\text { ment or } \\
\text { institution }\end{array}$ & nucleation mode & size & activated fraction & residence time \\
\hline Chou et al. (2012) & $\begin{array}{l}\text { diesel and wood } \\
\text { burning soot }\end{array}$ & CFDC-P & PINC & $\begin{array}{l}\text { deposition and } \\
\text { condensation }\end{array}$ & $\begin{array}{l}\text { mean mobility diameters: } \\
60 \text { to } 180 \mathrm{~nm} \text { for diesel soot, } \\
100 \text { to } 270 \mathrm{~nm} \text { for wood burn- } \\
\text { ing particles }\end{array}$ & $0.1 \%, 1 \%$ and $5 \%$ & n.a. \\
\hline Crawford et al. (2011) & $\begin{array}{l}\text { CAST and mini- } \\
\text { CAST propane soot } \\
\text { with different OC } \\
\text { content }\end{array}$ & CECC & AIDA & deposition & modal diameter $0.3 \mu \mathrm{m}$ & $0.1 \%$ and $1 \%$ & 24 to $86 \mathrm{~s} \mathrm{~K}^{-1}$ \\
\hline Demirdjian et al. (2009) & $\begin{array}{l}\text { aviation kerosene } \\
\text { flame soot }\end{array}$ & $\mathrm{CS}$ & CINaM & deposition & bulk sample & n.a. & n.a. \\
\hline DeMott (1990) & $\begin{array}{l}\text { acetylene burner } \\
\text { soot }\end{array}$ & CECC & $\mathrm{CSU}$ & immersion & 0.08 and $0.12 \mu \mathrm{m}$ & 0.1 to $3 \%$ & $30 \mathrm{sK}^{-1}, 60 \mathrm{sK}^{-1}$ \\
\hline DeMott et al. (1999) & $\begin{array}{l}\text { Degussa lamp } \\
\text { black soot }\end{array}$ & CFDC-C & $\mathrm{CSU}$ & deposition & $\begin{array}{l}\text { number mean } \\
d=240 \mathrm{~nm} \\
\sigma=1.6\end{array}$ & $1,10,100 \%$ & $11-15 \mathrm{~s}$ \\
\hline Diehl and Mitra (1998) & $\begin{array}{l}\text { kerosine burner ex- } \\
\text { haust }\end{array}$ & VWT & UMainz & $\begin{array}{l}\text { immersion and } \\
\text { contact }\end{array}$ & $\begin{array}{l}\text { initially } 0.1 \text { to } 0.12 \mu \mathrm{m} \text {, } \\
\text { aggregates up to } 1 \mu \mathrm{m}\end{array}$ & n.a. & n.a. \\
\hline Dymarska et al. (2006) & $\begin{array}{l}\text { n-hexane soot, } \\
\text { lamp black, } \\
\text { furnace black, } \\
\text { channel black }\end{array}$ & CS-FDC & UBC & $\begin{array}{l}\text { deposition/ } \\
\text { condensation }\end{array}$ & 1 to $20 \mu \mathrm{m}$ & n.a. & $\begin{array}{l}600 \mathrm{~s} \mathrm{~K}^{-1}, \\
\text { images every } \\
10 \mathrm{~s} ; \text { one } \\
\text { experiment: } 8 \mathrm{~h} \\
\text { at constant } \\
S_{\mathrm{i}} \text { and } T\end{array}$ \\
\hline Fornea et al. (2009) & $\begin{array}{l}\text { carbon lamp } \\
\text { black }\end{array}$ & $\mathrm{CS}$ & Texas A\&M U & contact & 250 to $300 \mu \mathrm{m}$ & 0 to 1 & $60 \mathrm{sK}^{-1}$ \\
\hline Friedman et al. (2011) & $\begin{array}{l}\text { CAST propane } \\
\text { soot with low } \\
\text { OC content, } \\
\text { uncoated and } \\
\text { coated }\end{array}$ & CFDC-P & PNNL-CIC & $\begin{array}{l}\text { deposition/ } \\
\text { condensation }\end{array}$ & $100,200,400 \mathrm{~nm}$ & $\begin{array}{l}1 \% \text {, spectra } \\
\text { (ice/droplet } \\
\text { discrimination not } \\
\text { possible) }\end{array}$ & $12 \mathrm{~s}$ \\
\hline Gorbunov et al. (2001) & $\begin{array}{l}\text { soot produced } \\
\text { from a thermal } \\
\text { decomposition } \\
\text { aerosol gen- } \\
\text { erator and a } \\
\text { benzene/toluene } \\
\text { combustion genera- } \\
\text { tor }\end{array}$ & DMCC & $\begin{array}{l}\text { Urban Pollu- } \\
\text { tion Research } \\
\text { Centre, London }\end{array}$ & $\begin{array}{l}\text { deposition/ } \\
\text { condensation/ } \\
\text { contact? }\end{array}$ & $\begin{array}{l}\text { mean diameter } \\
0.02 \text { to } 2 \mu \mathrm{m}\end{array}$ & $10^{-8}$ to $50 \%$ & $20 \mathrm{~min}$ \\
\hline Kanji and Abbatt (2006) & n-hexane soot & CS-FDC & UToronto & deposition & 0.5 to $5 \mu \mathrm{m}$ & $10^{-5}$ & $\begin{array}{l}40 \text { to } 60 \mathrm{sK}^{-1}, 6 \mathrm{~s} \\
\text { per } 1 \% \text { change in } \\
\mathrm{RH}_{\mathrm{i}}\end{array}$ \\
\hline Kanji et al. (2011) & $\begin{array}{l}\text { graphite spark } \\
\text { generator soot }\end{array}$ & $\begin{array}{l}\text { CFDC-C } \\
\text { and CECC }\end{array}$ & $\begin{array}{l}\text { UToronto, } \\
\text { CSU, AIDA }\end{array}$ & $\begin{array}{l}\text { deposition/ } \\
\text { condensation }\end{array}$ & $\begin{array}{l}0.02 \text { to } 0.45 \mu \mathrm{m}, \quad \text { number } \\
\text { mode }=0.15 \mu \mathrm{m}\end{array}$ & $0.1 \%$ & $\begin{array}{l}9 \mathrm{~s} \text { (UT-CFDC), } \\
4 \text { to } 5 \mathrm{~s} \text { (CSU- } \\
\text { CFDC), } \\
30 \text { to } 60 \mathrm{~s} \mathrm{~K}^{-1} \\
\text { (AIDA) }\end{array}$ \\
\hline Kireeva et al. (2009) & $\begin{array}{l}\text { lamp black, furnace } \\
\text { black, and more } \\
\text { soot types from } \\
\text { different } \\
\text { combustion } \\
\text { sources, some } \\
\text { modified with } \\
\text { organic } \\
\text { substances }\end{array}$ & $\mathrm{CS}$ & UMoscow & immersion & n.a. & $\begin{array}{l}\text { n.a. (numerous } \\
\text { particles per } \\
\text { droplet) }\end{array}$ & $40 \mathrm{~s} \mathrm{~K}^{-1}$ \\
\hline Koehler et al. (2009) & soot & CFDC-C & $\mathrm{CSU}$ & $\begin{array}{l}\text { deposition/ } \\
\text { condensation }\end{array}$ & 100,200 and $250 \mathrm{~nm}$ & $\begin{array}{l}\text { spectra, } \\
\approx 10^{-4} \text { to } 10^{-2} \\
\text { before homogeneous } \\
\text { freezing }\end{array}$ & $11 \mathrm{~s}$ \\
\hline Möhler et al. (2005b) & $\begin{array}{l}\text { CAST soot with } \\
\text { different OC } \\
\text { content }\end{array}$ & CECC & AIDA & deposition & $\begin{array}{l}\text { CS16 soot: mean } \\
d=220 \mathrm{~nm}, \text { CS} 40 \text { soot: } \\
\text { mean } d=110 \mathrm{~nm}\end{array}$ & $\begin{array}{l}\text { n. a. for CS16, } \\
<1 \% \text { for CS40 }\end{array}$ & 15 to $600 \mathrm{~s} \mathrm{~K}^{-1}$ \\
\hline Möhler et al. (2005a) & $\begin{array}{l}\text { graphite spark } \\
\text { generator soot }\end{array}$ & CECC & AIDA & deposition & $\begin{array}{l}\text { count median diameters: } 70 \text { to } \\
140 \mathrm{~nm}\end{array}$ & $\leq 0.3 \%$ & 17 to $100 \mathrm{sK}^{-1}$ \\
\hline Popovicheva et al. (2008) & $\begin{array}{l}\text { lamp black, } \\
\text { furnace black, } \\
\text { channel black, } \\
\text { and soot from } \\
\text { different combus- } \\
\text { tion sources }\end{array}$ & $\mathrm{CS}$ & UMoscow & immersion & $\begin{array}{l}0.01 \text { to } 0.25 \mu \mathrm{m} \text {, depending on } \\
\text { soot type }\end{array}$ & $\begin{array}{l}\text { n.a. (numerous } \\
\text { particles per } \\
\text { droplet) }\end{array}$ & $40 \mathrm{sK}^{-1}$ \\
\hline Suzanne et al. (2003) & kerosene soot & $\mathrm{CS}$ & CINaM & deposition & bulk sample & n.a. & n.a. \\
\hline Tishkova et al. (2011) & $\begin{array}{l}\text { aircraft engine } \\
\text { combustor soot }\end{array}$ & $\mathrm{CS}$ & CINaM & deposition & bulk sample & n.a. & n.a. \\
\hline
\end{tabular}


Table 3. Laboratory experiments with bioaerosols.

\begin{tabular}{|c|c|c|c|c|c|c|c|}
\hline Reference & material & $\begin{array}{l}\text { type of in- } \\
\text { strument }\end{array}$ & $\begin{array}{l}\text { name of instru- } \\
\text { ment or } \\
\text { institution }\end{array}$ & nucleation mode & size & activated fraction & $\begin{array}{ll}\text { residence } & \text { time/ } \\
\text { cooling rate } & \end{array}$ \\
\hline Ahern et al. (2007) & $\begin{array}{l}\text { Pseudomonas } \\
\text { isolates from } \\
\text { cloud- and } \\
\text { rainwater }\end{array}$ & DSC & UEastLondon & immersion & n. a. & n. a. & $60 \mathrm{~s} \mathrm{~K}^{-1}$ \\
\hline Alpert et al. (2011a) & marine diatoms & CS-FDC & $\begin{array}{l}\text { Stony } \\
\text { Brook U }\end{array}$ & immersion & $\approx 5 \mu \mathrm{m}$ & 0 to 1 (spectra) & $6 \mathrm{~s} \mathrm{~K}^{-1}$ \\
\hline Attard et al. (2012) & $\begin{array}{l}\text { Pseudomonas syringae } \\
\text { and Pseudomonas fluo- } \\
\text { rescens }\end{array}$ & DFA & UBP & immersion & $\begin{array}{l}\text { length: } 1 \mu \mathrm{m} \text {, surface area: } \\
5 \mu \mathrm{m}^{2}\end{array}$ & $10^{-5}$ to 1 & $480 \mathrm{~s} \mathrm{~K}^{-1}$ \\
\hline Chernoff and Bertram (2010) & Snomax ${ }^{\mathrm{TM}}$ & CS-FDC & UBC & $\begin{array}{l}\text { deposition and } \\
\text { condensation }\end{array}$ & $\begin{array}{l}\text { mean diameters: } \\
5.8 \text { and } 15.9 \mu \mathrm{m} \\
\text { (two different } \\
\text { nebulizers) }\end{array}$ & $0.1 \%$ to $1 \%$ & $600 \mathrm{~s} \mathrm{~K}^{-1}$ \\
\hline Constantinidou et al. (1990) & $\begin{array}{l}\text { Pseudomonas syringae } \\
\text { isolated } \\
\text { from air and rainwater }\end{array}$ & DFA & UWisconsin & immersion & n. a. & n. a. & n. a. \\
\hline DeMott et al. (2011) & Snomax $^{\mathrm{TM}}$ & $\begin{array}{l}\text { CFDC-C } \\
\text { and CECC }\end{array}$ & CSU and AIDA & $\begin{array}{l}\text { deposition and } \\
\text { condensation }\end{array}$ & n. a. & $10^{-5}$ to $10^{-2}$ & n. a. \\
\hline Diehl et al. (2001) & $\begin{array}{l}\text { Pine, birch, oak } \\
\text { and grass pollens }\end{array}$ & $\begin{array}{l}\text { CS-FDC } \\
\text { and ISDC }\end{array}$ & UMainz & $\begin{array}{l}\text { deposition and } \\
\text { condensation }\end{array}$ & $20-70 \mu \mathrm{m}$ & 0 to 1 (spectra) & $\begin{array}{l}\text { several minutes for } \\
\text { deposition } \\
\text { nucleation, }<1 \mathrm{~min} \\
\text { for } \\
\text { condensation } \\
\text { nucleation }\end{array}$ \\
\hline Diehl et al. (2002) & $\begin{array}{l}\text { Pine, birch, oak } \\
\text { and grass pollens }\end{array}$ & VWT & UMainz & $\begin{array}{l}\text { immersion and } \\
\text { contact }\end{array}$ & $25-70 \mu \mathrm{m}$ & n. a. & n. a. \\
\hline Gross et al. (1983) & $\begin{array}{l}\text { Pseudomonas } \\
\text { syringae, different } \\
\text { strains }\end{array}$ & DFA & $\begin{array}{l}\text { Washington } \\
\text { State U }\end{array}$ & immersion & n. a. & $10^{-7}$ to 0.0043 & $120 \mathrm{~s}$ \\
\hline Hirano et al. (1985) & $\begin{array}{l}\text { ice nucleation active } \\
\text { bacteria on oat leaves }\end{array}$ & FA & UWisconsin & immersion & n. a. & $10^{-7}$ to 0.008 & n. a. \\
\hline Iannone et al. (2011) & Cladosporium spores & CS-FDC & UBC & immersion & $\begin{array}{l}\text { average diameter: } \\
3.2 \mu \mathrm{m}\end{array}$ & 0.002 to 1 & $12 \mathrm{sK}^{-1}$ \\
\hline Jones et al. (2011) & Snomax ${ }^{\mathrm{TM}}$ & CFDC-C & $\begin{array}{l}\text { CSU and } \\
\text { MINC }\end{array}$ & $\begin{array}{l}\text { deposition/ } \\
\text { condensation }\end{array}$ & mostly $<1 \mu \mathrm{m}$ & $0.1 \%$ & $\approx 10 \mathrm{~s}$ \\
\hline Jayaweera and Flanagan (1982) & $\begin{array}{l}\text { Pseudomonas species, } \\
\text { unidentified microbac- } \\
\text { teria, Penicillium dig- } \\
\text { itatum, Cladosporium } \\
\text { herbarum, Penicillium } \\
\text { notatum, Penicil- } \\
\text { lium frequentes and } \\
\text { Rhizopus } \\
\text { stolonifera spores iso- } \\
\text { lated from air }\end{array}$ & DFA & UAlaska & immersion & $\begin{array}{l}\text { bacterial cells: } \\
\text { average length } \\
0.2-1.1 \mu \mathrm{m}\end{array}$ & $\begin{array}{l}1 \% \text { for spores, } \\
5-10 \% \text { for bacteria }\end{array}$ & n. a. \\
\hline Junge and Swanson (2008) & $\begin{array}{l}\text { Arctic and Antarc- } \\
\text { tic sea-ice bacterial } \\
\text { isolates }\end{array}$ & FDNC & UWashington & immersion & n. a. & n. a. & n. a. \\
\hline Kanji et al. (2011) & $\begin{array}{l}\text { Pseudomonas } \\
\text { syringae } \\
\text { Snomax }^{\mathrm{TM}}\end{array} \quad$ and & CFDC-P & UToronto & $\begin{array}{l}\text { deposition and } \\
\text { condensation }\end{array}$ & $\begin{array}{l}\text { size ranges } \\
\text { between } 0.04 \text { and } \\
2 \mu \mathrm{m} \text {, number } \\
\text { modes at } 0.1 \text { and } \\
0.7 \mu \mathrm{m}\end{array}$ & $0.1 \%$ & $9-11 \mathrm{~s}$ \\
\hline Knopf et al. (2011) & marine diatoms & CS-FDC & $\begin{array}{l}\text { Stony } \\
\text { Brook U }\end{array}$ & $\begin{array}{l}\text { deposition and immer- } \\
\text { sion }\end{array}$ & $\approx 5 \mu \mathrm{m}$ & n.a. & n.a. \\
\hline Koop and Zobrist (2009) & $\begin{array}{l}\text { Snomax }{ }^{\mathrm{TM}} \text {, insects } \\
\text { and larvae }\end{array}$ & DSC & $\begin{array}{l}\text { UBielefeld/ } \\
\text { ETHZ }\end{array}$ & immersion & n.a. & n.a. & $6 \mathrm{sK}^{-1}$ \\
\hline Levin and Yankofsky (1983) & M1 bacteria & VWT & $\begin{array}{l}\text { UCalifornia, } \\
\text { L.A. }\end{array}$ & $\begin{array}{l}\text { immersion and } \\
\text { contact }\end{array}$ & n.a. & n.a. & $\leq 240 \mathrm{~s}$ \\
\hline Lindemann et al. (1982) & $\begin{array}{l}\text { Pseudomonas } \\
\text { syringae and Erwinia } \\
\text { herbicola isolated from } \\
\text { air }\end{array}$ & FA & UWisconsin & immersion & n.a. & n.a. & n.a. \\
\hline Lindow et al. (1989) & $\begin{array}{l}\text { Pseudomonas } \\
\text { syringae strain 31R1 }\end{array}$ & DFA & $\begin{array}{l}\text { UCalifornia, } \\
\text { Berkeley }\end{array}$ & immersion & n.a. & $10^{-8}$ & n.a. \\
\hline Maki et al. (1974) & $\begin{array}{l}\text { Pseudomonas } \\
\text { syringae }\end{array}$ & DFA & $\begin{array}{l}\text { freezing } \\
\text { nucleus } \\
\text { spectrometer }\end{array}$ & immersion & n. a. & $10^{-8}$ to 0.01 & n.a. \\
\hline
\end{tabular}


Table 3. Continued.

\begin{tabular}{|c|c|c|c|c|c|c|c|}
\hline Reference & material & $\begin{array}{l}\text { type of in- } \\
\text { strument }\end{array}$ & $\begin{array}{l}\text { name of instru- } \\
\text { ment or } \\
\text { institution }\end{array}$ & nucleation mode & size & activated fraction & $\begin{array}{l}\text { residence time/ } \\
\text { cooling rate }\end{array}$ \\
\hline Maki and Willoughby (1978) & $\begin{array}{l}\text { Pseudomonas fluorescens } \\
\text { isolated from leaves, } \\
\text { lake/stream } \\
\text { water and/or snow }\end{array}$ & $\begin{array}{l}\text { DFA and } \\
\text { DMCC }\end{array}$ & $\begin{array}{l}\text { UWyoming and } \\
\text { CSU }\end{array}$ & immersion & $1 \mu \mathrm{m} \times 3-5 \mu \mathrm{m}$ & $2 \%$ to $94 \%$ & n.a. \\
\hline Möhler et al. (2008b) & $\begin{array}{l}\text { Pseudomonas } \\
\text { syringae, Pseu- } \\
\text { domonas viridiflava, } \\
\text { Erwinia herbicola and } \\
\text { Snomax }^{\mathrm{TM}}\end{array}$ & CECC & AIDA & $\begin{array}{l}\text { immersion and } \\
\text { condensation }\end{array}$ & $\begin{array}{l}\text { median diameter of } \\
\text { bacterial cells: } \\
0.6 \text { to } 0.8 \mu \mathrm{m}\end{array}$ & $0.07 \%$ to $23 \%$ & $\begin{array}{l}\text { immersion freez- } \\
\text { ing: a few seconds } \\
\text { to a few min- } \\
\text { utes; condensation } \\
\text { freezing: } \\
\approx 80 \mathrm{~s} \mathrm{~K}^{-1}\end{array}$ \\
\hline Morris et al. (2008) & $\begin{array}{l}\text { Pseudomonas } \\
\text { syringae isolated from rain, } \\
\text { snow, alpine } \\
\text { streams, lakes and } \\
\text { wild plants }\end{array}$ & DFA & INRA & immersion & n.a. & $10^{-7}$ & n.a. \\
\hline Mortazavi et al. (2008) & $\begin{array}{l}\begin{array}{l}\text { Microbacterium, } \\
\text { thomonas, } \\
\text { Acinetobacter, } \\
\text { Bateillus, }\end{array} \\
\begin{array}{l}\text { Suteimonas, } \\
\text { unspecified } \\
\text { bacteria isolated from snow }\end{array}\end{array}$ & DFA & McGill U & immersion & n.a. & n.a. & $60 \mathrm{sK}^{-1}$ \\
\hline Obata et al. (1999) & Pseudomonas antarctica & FA & Kansai U & immersion & n.a. & $10^{-7}$ to 0.2 & $60 \mathrm{sK}^{-1}$ \\
\hline Pouleur et al. (1992) & $\begin{array}{l}\text { Fusarium avanaceum, } \\
\text { Fusarium acuminatum }\end{array}$ & DFA & ULaval Québec & immersion & n.a. & n.a. & $200 \mathrm{sK}^{-1}$ \\
\hline Pummer et al. (2012) & $\begin{array}{l}15 \text { different pollen } \\
\text { species, Snomax }\end{array}$ & EDF & TU Wien & immersion & 13 to $65 \mu \mathrm{m}$ & n.a. & $30-60 \mathrm{sK}^{-1}$ \\
\hline Sands et al. (1982) & $\begin{array}{l}\text { Pseudomonas } \\
\text { syringae isolated from rain } \\
\text { and hail }\end{array}$ & n.a. & $\begin{array}{l}\text { Montana State } \\
\text { U }\end{array}$ & immersion & n.a. & n.a. & n.a. \\
\hline Vali et al. (1976) & $\begin{array}{l}\text { Pseudomonas } \\
\text { syringae, leaf litter }\end{array}$ & DFA & UWyoming & immersion & $\begin{array}{l}\text { length of bacterial cell: } \\
2 \mu \mathrm{m}\end{array}$ & $2 \times 10^{-6}$ to $5 \times 10^{-5}$ & n.a. \\
\hline von Blohn et al. (2005) & tree and grass pollens & VWT & UMainz & immersion & $26-28 \mu \mathrm{m}$ & n.a. & n.a. \\
\hline Ward and DeMott (1989) & Snomax ${ }^{\mathrm{TM}}$ & $\begin{array}{l}\text { IMCC and } \\
\text { CECC }\end{array}$ & $\mathrm{CSU}$ & $\begin{array}{l}\text { condensation and } \\
\text { immersion }\end{array}$ & n.a. & n.a. & $\begin{array}{l}\approx 180-300 \mathrm{sin} \\
\text { IMCC, } 60 \mathrm{~s} \mathrm{~K}^{-1} \text { in } \\
\text { CECC }\end{array}$ \\
\hline Wood et al. (2002) & Snomax ${ }^{\mathrm{TM}}$ & FDNC & UWashington & immersion & $<0.2 \mu \mathrm{m}$ (filtrate) & n.a. & n.a. \\
\hline Worland and Block (1999) & $\begin{array}{l}\text { Pseudomonas species iso- } \\
\text { lated from the guts of bee- } \\
\text { tles }\end{array}$ & DFA & $\begin{array}{l}\text { British Antarc- } \\
\text { tic Survey }\end{array}$ & immersion & n.a. & $10^{-6}$ & n.a. \\
\hline Yankofsky et al. (1981) & M1 bacteria & DFA & Tel Aviv U & immersion & $d \geq 0.4 \mu \mathrm{m}$ & $10^{-6}$ to 0.01 & n.a. \\
\hline
\end{tabular}

bioaerosols, in particular bacteria, the ability to nucleate ice is a selective property. Only a small number of bacterial strains and fungal species have been identified as ice nucleation active (INA) at high subzero temperatures. It has been shown that these possess an ice nucleation active protein located in the outer cell wall which has structural similarities to the crystal lattice of ice (Govindarajan and Lindow, 1988; Kajava and Lindow, 1993). Even among these INA bacteria, only a small fraction of all cells actually nucleates ice at temperatures roughly higher then $-10^{\circ} \mathrm{C}$ (Hirano and Upper, 1995). Most experiments with biological particles are conducted as so-called droplet-freezing assays (Vali, 1971; Vali et al., 1976), i.e. testing for immersion freezing. Most of the data points in Fig. 5a therefore lie on the water saturation line. Only for Snomax ${ }^{\mathrm{TM}}$, an artificial snow inducer consisting of freeze-dried Pseudomonas syringae bacteria cells, cell debris and dried culture medium (Lagriffoul et al., 2010), deposition nucleation has been studied extensively (Chernoff and
Bertram, 2010; Jones et al., 2011; Kanji et al., 2011; DeMott et al., 2011).

More results on freezing experiments with biological particles, also from other habitats, are discussed in Després et al. (2012).

\subsubsection{Solid ammonium sulfate}

At conditions relevant for cirrus clouds in the upper troposphere and lower stratosphere, crystalline ammonium sulfate particles have been observed to nucleate ice efficiently at water-subsaturated conditions, both as deposition nuclei (e.g., Abbatt et al., 2006) and as immersion nuclei in solution droplets (e.g., Hung et al., 2002) (Fig. 5c). In contrast, Chen et al. (2000) observed ice formation on crystalline sulfate particles only at relative humidities higher than those required for homogeneous freezing. 
(a) submicron ATD and desert dusts

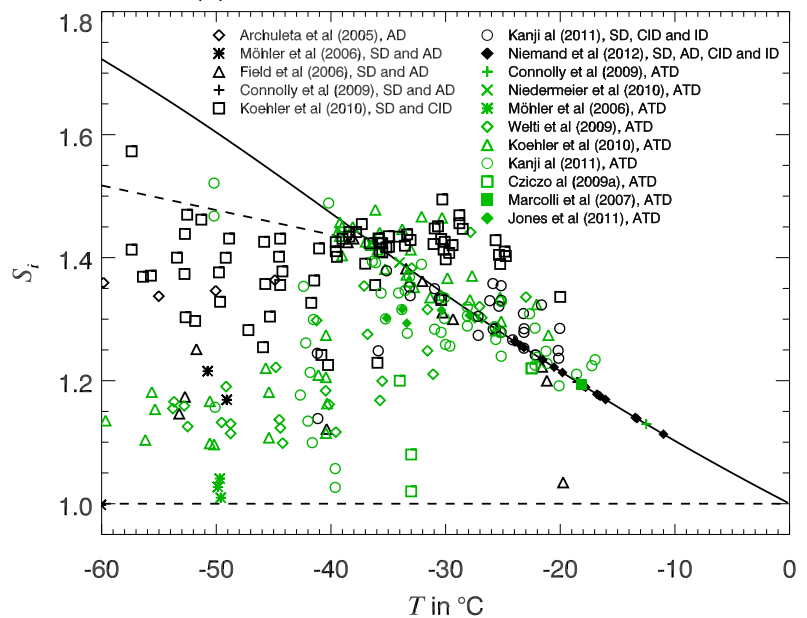

(c) supermicron ATD and desert dusts

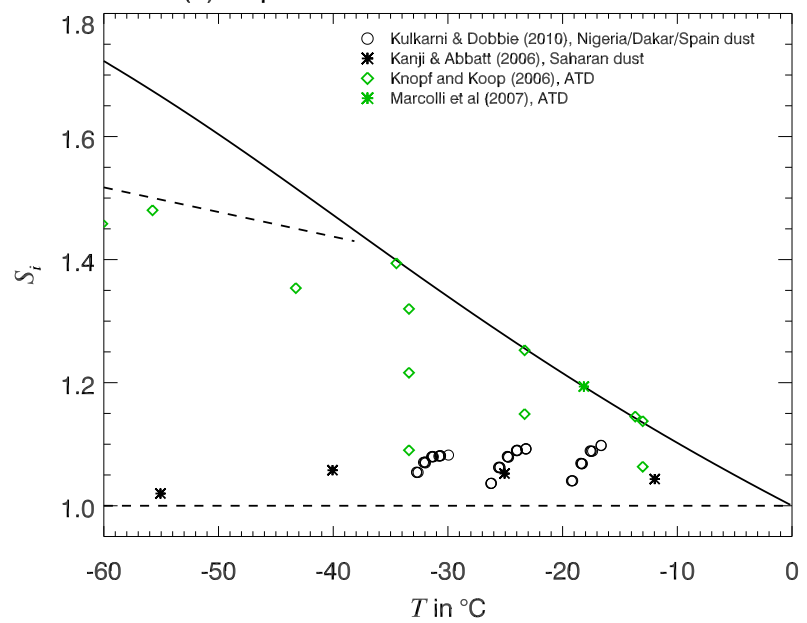

(b) submicron clay mineral dusts

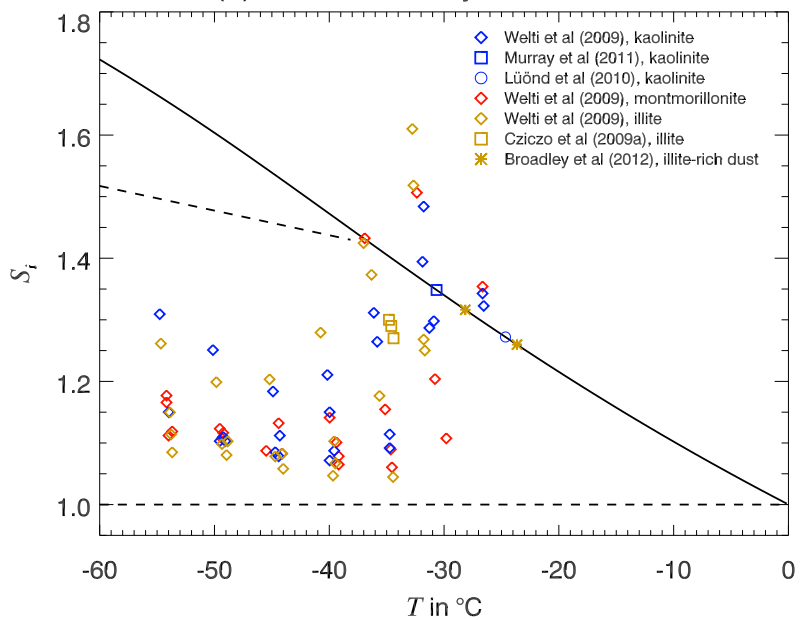

(d) supermicron clay mineral dusts

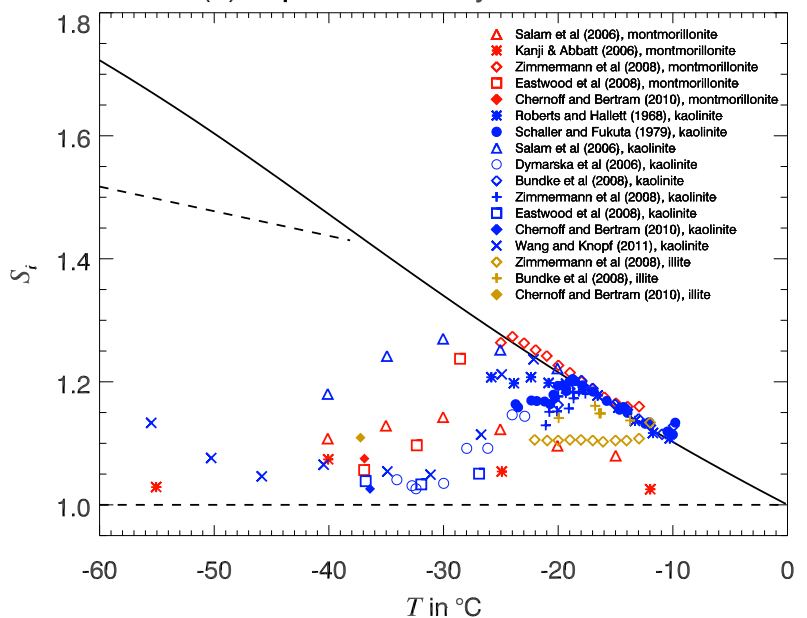

Fig. 3. Ice nucleation onset temperatures and saturation ratios for mineral dust particles.

(a) soot

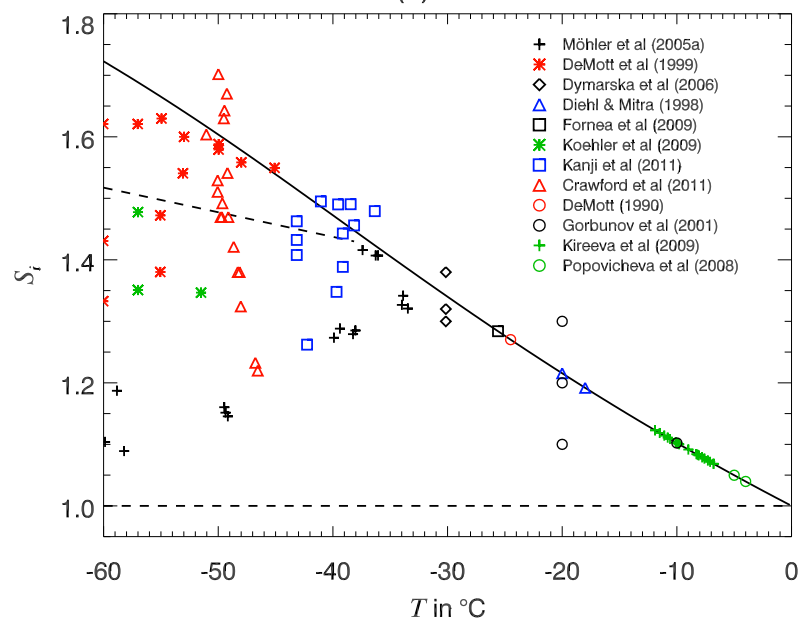

(b) soot - negative results

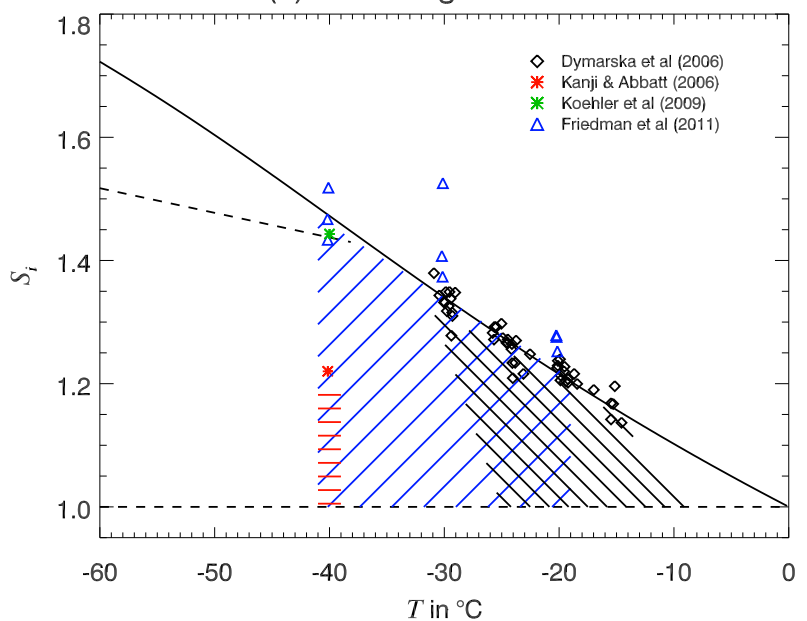

Fig. 4. (a) Ice nucleation onset temperatures and saturation ratios for soot. (b) Conditions under which ice nucleation on soot particles was not found or could not be distinguished from nucleation on the substrate. The dashed areas indicate the range of conditions which have been probed during the experimental trajectories to the indicated points. 
(a) bacteria

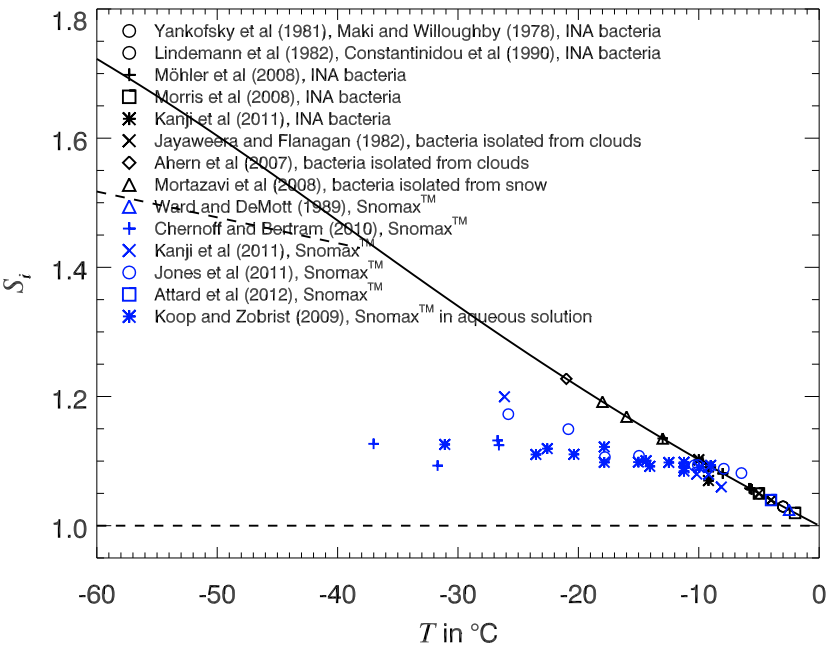

(c) solid ammonium sulfate

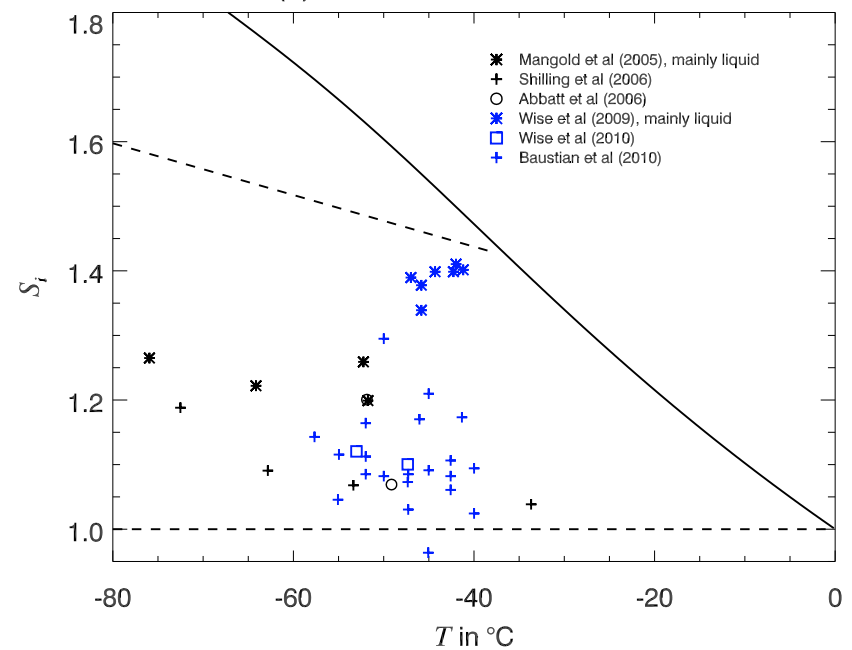

(b) other bioaerosols

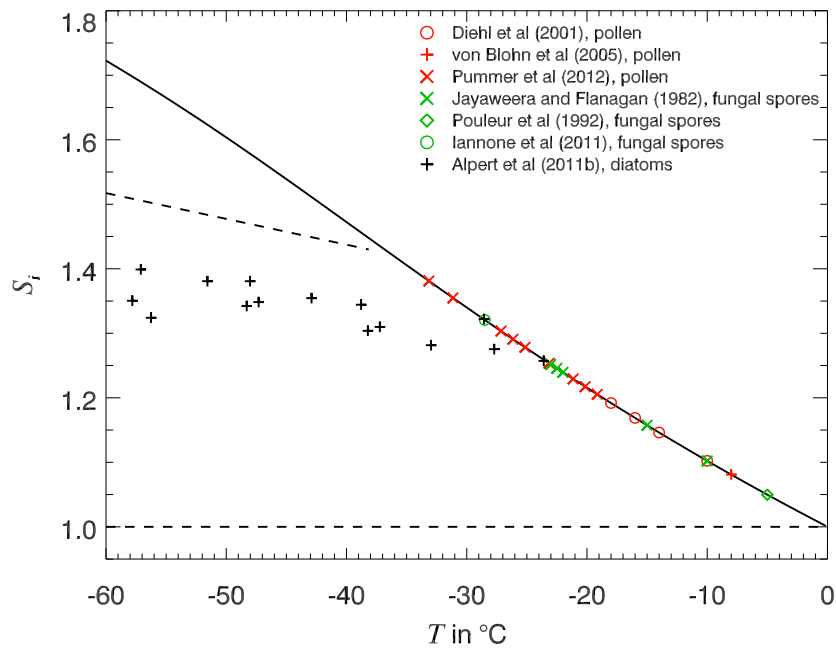

(d) organic and biomass burning aerosols

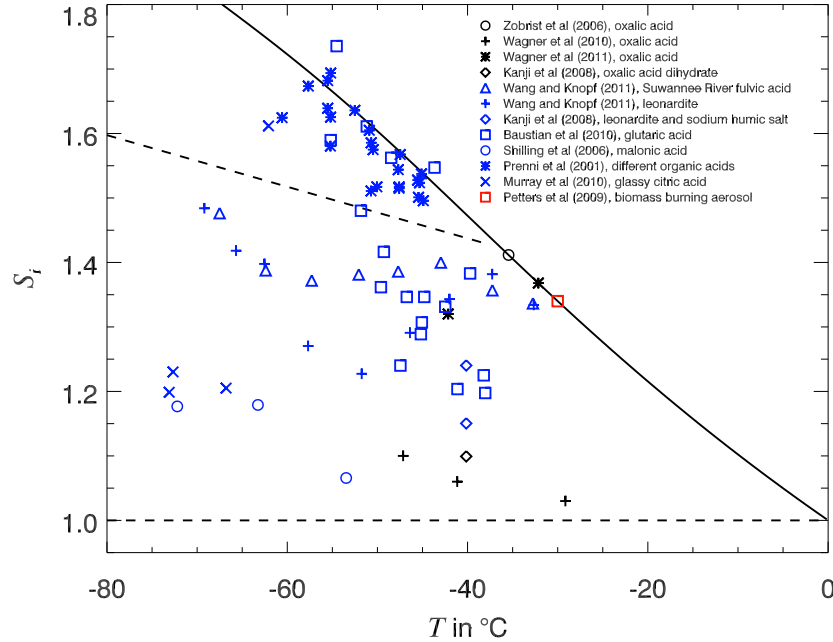

Fig. 5. Ice nucleation onset temperatures and saturation ratios for (a) bacteria, (b) other bioaerosols, (c) ammonium sulfate and (d) organic aerosols and biomass burning particles. Note the different temperature ranges. The data from Pummer et al. (2012) refer to median freezing temperatures.

\subsubsection{Organic acids and humic-like substances}

Also some organic acids in crystalline form have been observed to nucleate ice under cirrus conditions (Fig. 5d), most notably oxalic acid (Zobrist et al., 2006; Wagner et al., 2010) and malonic acid (Shilling et al., 2006). At temperatures below $-65^{\circ} \mathrm{C}$, citric acid aerosol particles in a glassy state have been observed to nucleate ice at $S_{\mathrm{i}}>1.2$ (Murray et al., 2010). Other organic substances, such as dicarboxylic acids (Prenni et al., 2001) or secondary organic products of the ozonolysis of various precursors (Prenni et al., 2009), were shown not to nucleate ice heterogeneously. Furthermore, Fig. 5d includes results for humic acids (produced by the degradation of dead organic matter) and biomass burning aerosols (tested solely at $-30^{\circ} \mathrm{C}$, Petters et al., 2009).

\subsubsection{Others}

In addition, a number of other components of the atmospheric aerosol are occasionally found to act as IN. Among these are volcanic ash particles (Durant et al., 2008; Hoyle et al., 2011; Steinke et al., 2011) and sea salt (Wise et al., 2012). No onset nucleation plots are shown for these particle types because of the limited number of measurements. Furthermore, artificial particles which usually do not occur in the atmosphere (e.g. silver iodide, metaldehyde, metal oxides), some of them being very efficient IN (Vonnegut, 1947; Fukuta, 1963), are excluded from this overview. 
(a) condensation/immersion/contact freezing

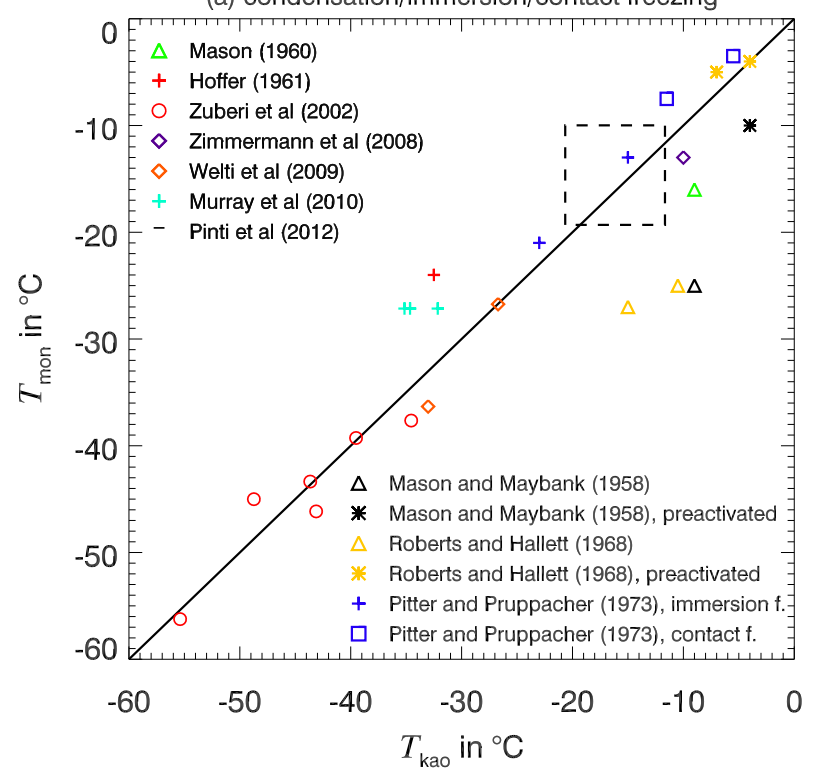

(b) deposition nucleation

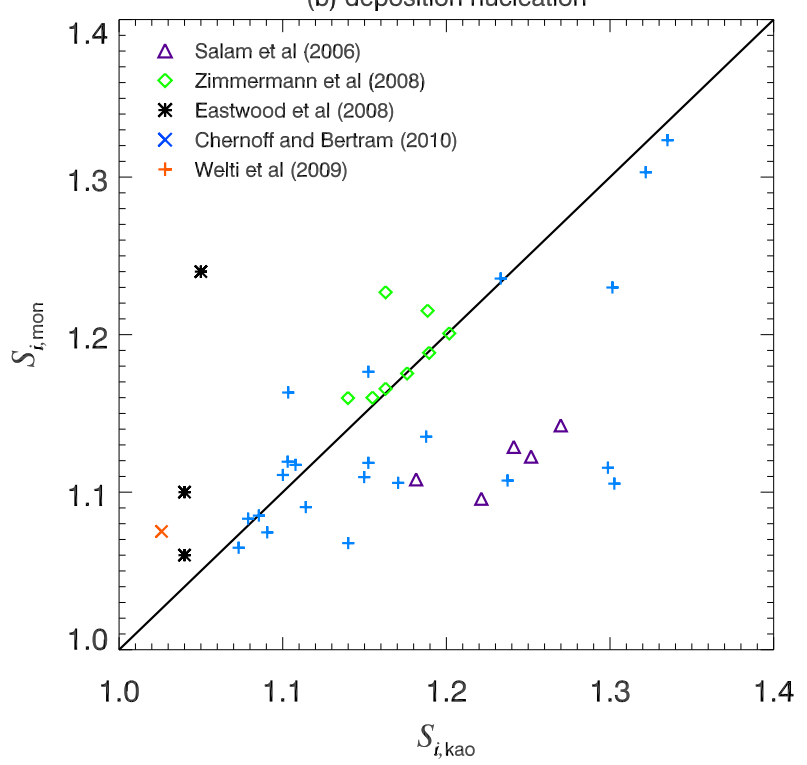

Fig. 6. (a) Freezing temperatures (onset or median) for kaolinite and montmorillonite under comparable experimental conditions. Includes immersion freezing experiments (Hoffer, 1961; Pitter and Pruppacher, 1973; Murray et al., 2010) and presumed condensation freezing experiments at water-supersaturated conditions (Zimmermann et al., 2008; Welti et al., 2009). The data by Welti et al. (2009) for 100 and $800 \mathrm{~nm}$-sized particles are interpolated to $\approx 5 \%$ supersaturation over water. For the mixing-cloud chamber experiments by Mason and Maybank (1958) and Mason (1960), the nucleation mode is uncertain. Zuberi et al. (2002) measured immersion nucleation in aqueous ammonium sulfate droplets, data are shown for the same weight percentages of kaolinite and montmorillonite. Pinti et al. (2012) show results for several different kaolinites and montmorillonites, as indicated by the dashed lines. (b) Saturation ratios at deposition nucleation onset for kaolinite and montmorillonite under comparable experimental conditions and temperature (for Welti et al. (2009), the data have been interpolated to the same temperatures). In Zimmermann et al. (2008)'s study, ice nucleation on montmorillonite was observed only at or slightly above water saturation, but no liquid water was seen. All other data in (b) are for deposition nucleation experiments, water saturation.

\subsection{Comparison of different minerals}

Natural mineral dust particles are usually internal mixtures of different clay minerals, quartz and other components. Laboratory studies have therefore often reverted to the use of pure minerals, in order to reduce the complexity encountered in natural dusts. For pure minerals, the chemical composition and the crystalline structure can be determined more accurately at least in theory. For example, Mason (1960) tried to relate the ice nucleation abilities of different minerals to their lattice structure. It should be noted that impurities in the naturally occurring minerals impede the interpretation of the results (see discussion below). Previous modelling studies have used measurements of ice nucleation of pure minerals as a basis for parametrizations, and have assumed for sensitivity experiments that montmorillonite is a better ice nucleus than kaolinite (Diehl et al., 2006; Lohmann and Diehl, 2006; Hoose et al., 2008; Storelvmo et al., 2008). Ideally, the ice nucleation properties of a complex natural dust particle can be inferred if the composition of the particle and the ice nucleation properties of all components are known. The most abundant minerals in the clay size fraction of mineral dust are kaolinite, illite and montmorillonite (Mason, 1960; Zimmer- mann et al., 2008). Their relative ice nucleation abilities are compared in the following, including only studies which examined kaolinite, montmorillonite and/or illite with the same methods and under comparable experimental conditions.

Figure 6a compares temperatures for the freezing onset or a specific active fraction of kaolinite and montmorillonite particles at otherwise comparable conditions (i.e. the same weight percent in Murray et al. (2010), the same particle sizes in Welti et al. (2009)). In the experiments by Mason and Maybank (1958), Mason (1960), Hoffer (1961) and Pitter and Pruppacher (1973), the particle sizes and active fractions are not well constrained, but are assumed to be similar for the kaolinite and montmorillonite experiments. Zimmermann et al. (2008) reported onset temperatures corresponding to a larger active fraction for kaolinite than for montmorillonite (2-3\% versus $1 \%)$.

As visible in Fig. 6a, no systematic difference between the ice nucleation temperatures of montmorillonite and kaolinite is found. The immersion freezing experiments with particle suspensions (Hoffer, 1961; Pitter and Pruppacher, 1973; Murray et al., 2010) and the contact freezing experiments (Pitter and Pruppacher, 1973) show higher freezing temperatures for montmorillonite, while the other experiments (for 

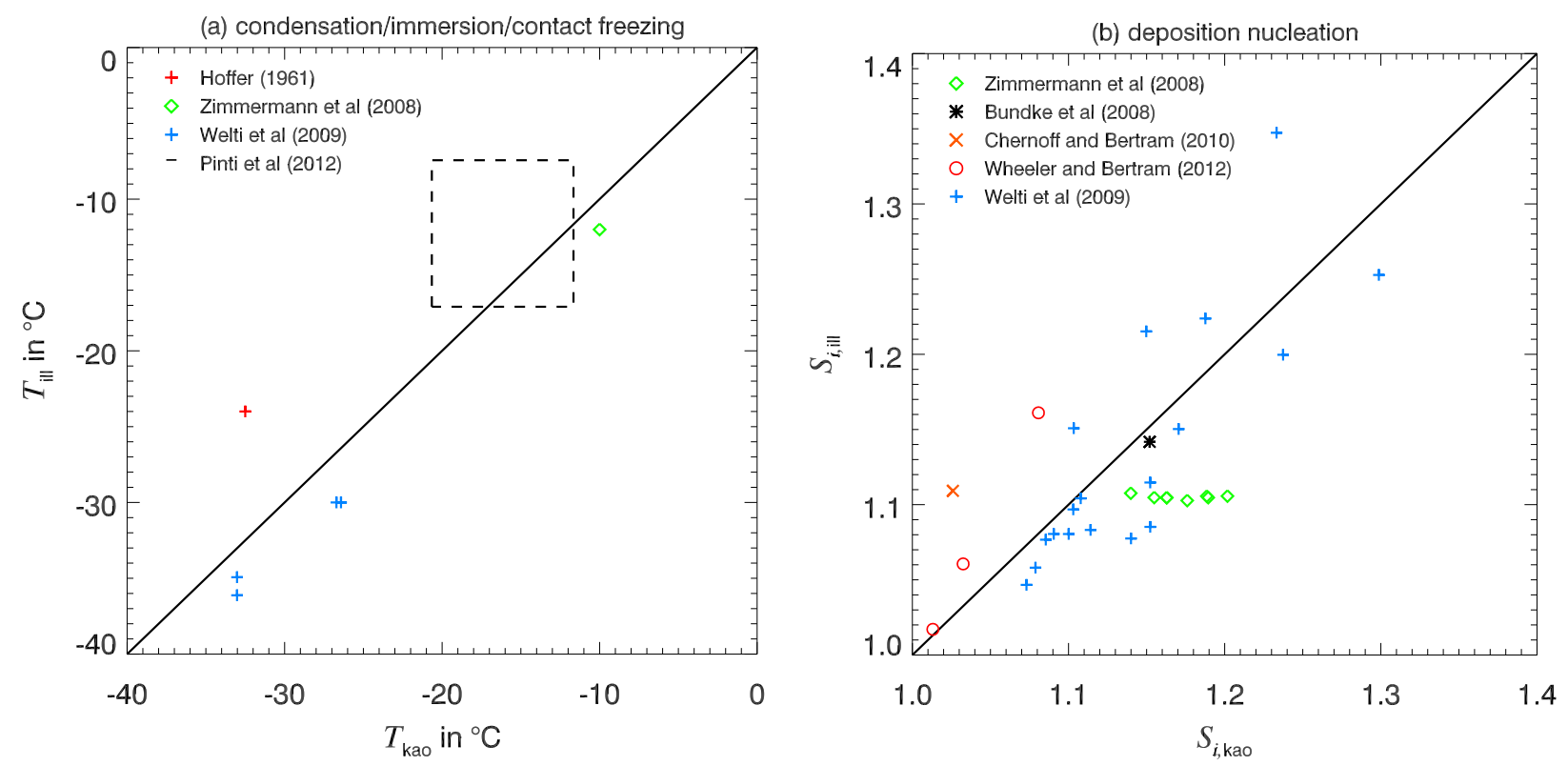

Fig. 7. (a) Freezing temperatures (onset or median) for kaolinite and illite under comparable experimental conditions. Includes immersion freezing experiments (Hoffer, 1961) and presumed condensation freezing experiments at water-supersaturated conditions (Zimmermann et al., 2008; Welti et al., 2009). The data by Welti et al. (2009) for 100 and $800 \mathrm{~nm}$-sized particles are interpolated to $\approx 5 \%$ supersaturation over water. Pinti et al. (2012) show results for several different kaolinites and illites, as indicated by the dashed lines. (b) Saturation ratios at nucleation onset for kaolinite and illite under comparable experimental conditions and temperature.

which the nucleation modes are not unambiguously determined) found higher freezing temperatures for kaolinite (Mason and Maybank, 1958; Mason, 1960; Roberts and Hallett, 1968; Zimmermann et al., 2008). Zuberi et al. (2002) found no significant difference between kaolinite and montmorillonite as immersion ice nucleus in aqueous ammonium sulfate droplets.

Also in deposition nucleation experiments, reported as supersaturation thresholds at fixed temperatures (Fig. 6b), the comparison of kaolinite versus montmorillonite remains inconclusive. Both a higher efficiency of kaolinite (Zimmermann et al., 2008; Eastwood et al., 2008; Chernoff and Bertram, 2010) and a higher efficiency of montmorillonite (Salam et al., 2007; Welti et al., 2009) are found.

Fewer studies have compared the ice nucleation ability of illite to that of kaolinite (Mason, 1960; Hoffer, 1961; Zimmermann et al., 2008; Bundke et al., 2008; Welti et al., 2009; Chernoff and Bertram, 2010). The results are summarized in Fig. 7. The data shown here are selected in the same way as for the comparison in Fig. 6. Similar to the kaolinitemontmorillonite comparison, no definite conclusions can be drawn about the nucleation ability of illite compared to kaolinite, because different experiments come to opposite results both expressed as onset temperatures or as onset saturation ratios.

The reason for the heterogeneity of these results may lie in the different origin and the purity of the samples which are used. Isono and Ibeke (1960) and Pinti et al. (2012) show that kaolinites, montmorillonites and illites from different sources can have different physical and chemical properties. Zimmermann et al. (2008) point out that the chemical composition of minerals, in particular of montmorillonite and illite, can be highly variable. Powder samples have usually undergone mechanical processing such as mechanical disaggregation and milling (Moll, 2002). Murray et al. (2010) mention that the commercially available minerals, which are used in some of the above studies, were acid washed or chemically treated. This may have affected their nucleation abilities. For deposition nucleation experiments, the dispersion method (wet or dry) may have influenced the results, because it may have a substantial impact on the hygroscopicity of the minerals (Herich et al., 2009). Furthermore, Mason and Maybank (1958) and Roberts and Hallett (1968) found that preactivation could reduce or even invert the differences in freezing onset between kaolinite and montmorillonite.

Based on the data summarized here, the validity of the common model assumption of the superior ice nucleation ability of montmorillonite compared to kaolinite has to be questioned.

\subsection{Natural dusts compared to dust surrogates}

Frequently, the commercially available Arizona Test Dust (ATD) is used in laboratory experiments as a surrogate for desert dusts (e.g., Knopf and Koop, 2006; Marcolli et al., 
Table 4. Laboratory experiments with solid ammonium sulfate particles.

\begin{tabular}{|c|c|c|c|c|c|c|c|}
\hline Reference & material & $\begin{array}{l}\text { type of in- } \\
\text { strument }\end{array}$ & $\begin{array}{l}\text { name of instru- } \\
\text { ment or } \\
\text { institution }\end{array}$ & nucleation mode & size & activated fraction & residence time \\
\hline Abbatt et al. (2006) & $\begin{array}{l}\text { solid ammonium } \\
\text { sulfate }\end{array}$ & $\begin{array}{l}\text { CECC, CS- } \\
\text { FDC }\end{array}$ & $\begin{array}{l}\text { AIDA, } \\
\text { UToronto }\end{array}$ & $\begin{array}{l}\text { deposition/ } \\
\text { condensation }\end{array}$ & $\begin{array}{l}\text { AIDA: diameters } \\
\geq 40 \text { to } 400 \mathrm{~nm}, \\
\text { CS-FDC: typically } \\
8 \mu \mathrm{m}\end{array}$ & $\begin{array}{l}\text { AIDA: } 0.1 \% \text { to } 1 \% \text {, } \\
\text { CS-FDC: } 10^{-5}\end{array}$ & $\begin{array}{l}\text { AIDA: n.a., } \\
\text { CS-FDC: } 6 \mathrm{~s} \\
\text { per } 1 \% \text { change in } \\
\mathrm{RH}_{\mathrm{i}}\end{array}$ \\
\hline Baustian et al. (2010) & $\begin{array}{l}\text { solid ammonium } \\
\text { sulfate }\end{array}$ & CS-FDC & CIRES & $\begin{array}{l}\text { deposition/ } \\
\text { condensation }\end{array}$ & $\begin{array}{l}0.5 \text { to } 10 \mu \mathrm{m} \text {, } \\
\text { mean: } 2.1 \mu \mathrm{m}\end{array}$ & $\approx 0.1 \%$ & n.a. \\
\hline Chen et al. (2000) & $\begin{array}{l}\text { solid and liquid } \\
\text { ammonium sulfate } \\
\text { and letovicite }\end{array}$ & CFDC-C & CSU & $\begin{array}{l}\text { homogeneous, } \\
\text { no heterogeneous } \\
\text { nucleation } \\
\text { observed }\end{array}$ & 0.05 and $0.2 \mu \mathrm{m}$ & $0.1 \%, 1 \%$ and $10 \%$ & $12 \mathrm{~s}$ \\
\hline Hung et al. (2002) & $\begin{array}{l}\text { mix of aqueous and crys- } \\
\text { talline ammonium sulfate }\end{array}$ & AFT & Harvard & $\begin{array}{l}\text { immersion freezing of } \\
\text { concentrated } \\
\text { aqueous solution } \\
\text { droplets }\end{array}$ & $0.3 \mu \mathrm{m}$ & $\approx 50 \%$ & $31 \mathrm{~s}$ \\
\hline Mangold et al. (2005) & $\begin{array}{l}\text { ammonium sulfate } \\
\text { particles, majority in liquid } \\
\text { phase, but possibly some } \\
\text { effloresced particles present }\end{array}$ & CECC & AIDA & $\begin{array}{l}\text { deposition/ } \\
\text { condensation }\end{array}$ & $\begin{array}{l}\text { number median } \\
d: 0.2 \text { to } 0.3 \mu \mathrm{m}\end{array}$ & n.a. & 20 to $25 \mathrm{~s} \mathrm{~K}^{-1}$ \\
\hline Shilling et al. (2006) & $\begin{array}{l}\text { solid ammonium } \\
\text { sulfate }\end{array}$ & CS-SDC & CIRES & $\begin{array}{l}\text { deposition/ } \\
\text { condensation/ } \\
\text { immersion }\end{array}$ & 1 to $10 \mu \mathrm{m}$ & $\geq 10^{-5}$ & $\approx 600 \mathrm{~s}$ \\
\hline Wise et al. (2009) & $\begin{array}{l}\text { solid ammonium } \\
\text { sulfate }\end{array}$ & CS-FDC & CIRES & $\begin{array}{l}\text { deposition/ } \\
\text { condensation }\end{array}$ & n. a. & n. a. & n. a. \\
\hline Wise et al. (2010) & $\begin{array}{l}\text { solid ammonium } \\
\text { sulfate with and } \\
\text { without coatings of } \\
\text { palmitic acid }\end{array}$ & CS-FDC & CIRES & deposition & $\begin{array}{l}1 \text { to } 10 \mu \mathrm{m} \text { with typical } \\
\text { values around } 5 \mu \mathrm{m}\end{array}$ & n. a. & n. a. \\
\hline Zuberi et al. (2001) & $\begin{array}{l}\text { solid ammonium } \\
\text { sulfate and letovicite }\end{array}$ & $\begin{array}{l}\text { CS and } \\
\text { DSC }\end{array}$ & MIT & $\begin{array}{l}\text { immersion freezing of } \\
\text { concentrated } \\
\text { aqueous solution } \\
\text { droplets }\end{array}$ & $\begin{array}{l}\text { droplet sizes: } \\
5 \text { to } 55 \mu \mathrm{m}, \\
\text { containing numerous } \\
\text { microcrystals }\end{array}$ & n.a. & $60 \mathrm{~s} \mathrm{~K}^{-1}$ \\
\hline
\end{tabular}

2007). ATD is milled, washed and heated in order to provide enough material of the desired size (Möhler et al., 2006). Alternatively, surface soil samples (e.g., Field et al., 2006; Kulkarni and Dobbie, 2010) or sedimented dust storm particles (e.g., Isono et al., 1959a; Niemand et al., 2012) have been studied. Ideally, these samples are only sieved to retrieve the small size fraction, but have not undergone any milling or further processing. It has been speculated that ATD could be more active than so-called natural (unprocessed) soil samples, either due to enhanced roughness resulting from the milling or due to a different mineralogical composition (Möhler et al., 2006). In Fig. 8, results from deposition nucleation experiments which tested both ATD and natural desert dusts under comparable conditions are summarized. Only a limited number of studies fulfils this requirement and allows such a direct comparison. In most experiments, natural desert dusts required higher supersaturations over ice for a comparable activation, provided that the data are compared with the same instrument, for the same active fraction, at similar temperatures and for similar particle sizes similar particle sizes. An exception to this observation are Kanji et al. (2008) and Möhler et al. (2006)'s data at low temperatures $\left(<-60^{\circ} \mathrm{C}\right)$.

Contrary to the above finding that natural desert dust samples might be relatively inefficient IN due to lower surface roughness and atmospheric aging, Conen et al. (2011) provide evidence for enhanced ice nucleation activity of agri- cultural soil samples compared to pure montmorillonite due to biological residues in the soil.

\subsection{Influence of coatings}

A number of experiments have investigated the effect of artificial aging (such as surface reactions and coatings) of mineral dust, soot and biological particles on their ice nucleation efficiency. These studies are of high relevance, because atmospheric aerosol particles frequently undergo processing by trace gases or in clouds. Table 6 lists pertinent experiments. Most studies focussed on the treatment with sulfuric acid, but also ammonium sulfate, nitric acid, secondary organic aerosol (SOA), ammonia, ozone and exposure to light were used. Intercomparison between different experiments is difficult because various coating methods have been applied. The resulting coating thicknesses are often poorly constrained and not necessarily evenly distributed over the particle size distribution. In Fig. 9, results from deposition and condensation freezing nucleation experiments with coated and uncoated mineral dust particles are summarized. The saturation ratios with respect to water for activation of a specific fraction of particles at otherwise similar conditions (temperature, particle size) are reported. Most measurements shown here report higher saturation ratios for coated particles than for uncoated ones, i.e. a deactivation of mineral dust by surface treatments. Where the saturation ratio with respect to 
Table 5. Laboratory experiments with organic acids, humic-like substances and biomass burning particles.

\begin{tabular}{|c|c|c|c|c|c|c|c|}
\hline Reference & material & $\begin{array}{l}\text { type of in- } \\
\text { strument }\end{array}$ & $\begin{array}{l}\text { name of instru- } \\
\text { ment or } \\
\text { institution }\end{array}$ & nucleation mode & size & activated fraction & residence time \\
\hline Baustian et al. (2010) & solid glutaric acid & CS-FDC & CIRES & $\begin{array}{l}\text { deposition/ } \\
\text { condensation }\end{array}$ & $\begin{array}{l}0.5 \text { to } 10 \mu \mathrm{m}, \\
\text { mean: } 2.4 \mu \mathrm{m}\end{array}$ & $\approx 0.1 \%$ & n.a. \\
\hline Beaver et al. (2006) & $\begin{array}{l}\text { aldehydes and } \\
\text { ketones }\end{array}$ & LFT & CIRES & $\begin{array}{l}\text { immersion freezing in } \\
\text { sulfuric acid } \\
\text { droplets }\end{array}$ & $<1 \mu \mathrm{m}$ & n.a. & n.a. \\
\hline DeMott et al. (2009) & biomass burning particles & CFDC-C & CSU & $\begin{array}{l}\text { deposition and } \\
\text { homogeneous }\end{array}$ & $100 \mathrm{~nm}$ & $10^{-5}$ to $10^{-1}$ & $15 \mathrm{~s}$ \\
\hline Kanji et al. (2008) & $\begin{array}{l}\text { leonardite, oxalic acid } \\
\text { dihydrate, sodium humic } \\
\text { salt, octyl-silica }\end{array}$ & CS-FDC & UToronto & $\begin{array}{l}\text { deposition and } \\
\text { condensation }\end{array}$ & $\begin{array}{l}\text { size n.a., surface area } \\
\text { determined }\end{array}$ & $\geq 10^{-5}$ & $\begin{array}{l}\text { 6s per } 1 \% \text { change } \\
\text { in } \mathrm{RH}_{\mathrm{i}}\end{array}$ \\
\hline Murray et al. (2010) & citric acid, glassy & CECC & AIDA & unknown & n.a. & $10^{-4}$ to $3.5 \times 10^{-3}$ & $\approx 36 \mathrm{~s} \mathrm{~K}^{-1}$ \\
\hline Petters et al. (2009) & biomass burning & CFDC-C & CSU & condensation & mode: 80 to $200 \mathrm{~nm}$ & $10^{-4}-10^{-2}$ & 4 to $5 \mathrm{~s}$ \\
\hline Prenni et al. (2001) & organic acids & CFDC-C & $\mathrm{CSU}$ & $\begin{array}{l}\text { deposition and } \\
\text { condensation }\end{array}$ & 50 and $100 \mathrm{~nm}$ & $1 \%$ and $10 \%$ & n. a. \\
\hline Prenni et al. (2009) & $\begin{array}{l}\text { secondary organic } \\
\text { aerosol generated } \\
\text { from ozonolysis of } \\
\text { alkenes }\end{array}$ & CFDC-C & $\mathrm{CSU}$ & condensation & mode: 80 to $200 \mathrm{~nm}$ & $\begin{array}{l}\text { no ice nucleation } \\
\text { detected }\end{array}$ & n. a. \\
\hline Shilling et al. (2006) & maleic acid & CS-SDC & CIRES & deposition & 1 to $10 \mu \mathrm{m}$ & $\geq 10^{-5}$ & $\approx 600 \mathrm{~s}$ \\
\hline Wagner et al. (2010) & $\begin{array}{l}\text { oxalic acid dihydrate } \\
\text { and sodium oxalate }\end{array}$ & CECC & AIDA & $\begin{array}{l}\text { deposition and } \\
\text { condensation }\end{array}$ & 0.03 to $0.8 \mu \mathrm{m}$ & $0.1 \%$ to $22 \%$ & $\approx 30$ to $100 \mathrm{sK}^{-1}$ \\
\hline Wagner et al. (2011) & oxalic acid & CECC & AIDA & immersion & $\geq 0.27 \mu \mathrm{m}$ & $\leq 0.18$ & $\approx 40 \mathrm{~s} \mathrm{~K}^{-1}$ \\
\hline Wagner et al. (2012) & $\begin{array}{l}\text { levoglucosan, raffinose, cit- } \\
\text { ric acid, HMMA and mix- } \\
\text { ture, glassy, pre-activated }\end{array}$ & CECC & AIDA & deposition & $\begin{array}{l}\text { number median } \approx 0.12 \\
\text { to } 0.14, \mu \mathrm{m}\end{array}$ & $\begin{array}{l}10 \text { to } 35 \% \text { of homoge- } \\
\text { neously freezing parti- } \\
\text { cles }\end{array}$ & n.a. \\
\hline Wang and Knopf (2011) & $\begin{array}{l}\text { Suwannee river } \\
\text { standard fulvic acid } \\
\text { (SRFA) }\end{array}$ & CS-FDC & $\begin{array}{l}\text { Stony } \\
\text { Brook U }\end{array}$ & deposition & mean: 2.0 to $2.4 \mu \mathrm{m}$ & $0.02 \%$ to $0.13 \%$ & $\begin{array}{l}60 \text { s per } 1.5 \% \\
\text { to } 2.3 \% \text { change in } \\
\mathrm{RH}_{\mathrm{i}}\end{array}$ \\
\hline Wang and Knopf (2011) & $\begin{array}{l}\text { Leonardite standard } \\
\text { humic acid }\end{array}$ & CS-FDC & $\begin{array}{l}\text { Stony } \\
\text { Brook U }\end{array}$ & deposition & mean: 1.7 to $3.3 \mu \mathrm{m}$ & $0.01 \%$ to $0.1 \%$ & $\begin{array}{l}60 \text { s per } 1.5 \% \\
\text { to } 2.3 \% \text { change in } \\
\mathrm{RH}_{\mathrm{i}}\end{array}$ \\
\hline Wilson et al. (2012) & $\begin{array}{l}\text { levoglucosan, raffinose, cit- } \\
\text { ric acid, HMMA and mix- } \\
\text { ture, glassy }\end{array}$ & CECC & AIDA & deposition & $\begin{array}{l}\text { mean: } 0.17 \mu \mathrm{m} \text {, INAS } \\
\text { densities given }\end{array}$ & $<0.3 \%$ & n.a. \\
\hline Wise et al. (2010) & palmitic acid & CS-FDC & CIRES & deposition & $\begin{array}{l}1 \text { to } 10 \mu \mathrm{m} \text { with typical } \\
\text { values around } 5 \mu \mathrm{m}\end{array}$ & n.a. & n.a. \\
\hline Zobrist et al. (2006) & $\begin{array}{l}\text { phthalic, adipic, } \\
\text { fumaric, succinic and } \\
\text { oxalic acid }\end{array}$ & DSC & ETHZ & immersion & n.a. & n.a. & $6 \mathrm{sK}^{-1}$ \\
\hline
\end{tabular}

water is above or close to 1 for the coated particles, this implies that at the given temperature the treated particles could not or only to a minor fraction be activated in the deposition mode, and that instead condensation of liquid water was required before ice formation. The largest changes in saturation ratio are found for coatings by SOA (Möhler et al., 2008a; Koehler et al., 2010). Also sulfuric acid and ammonium sulfate treatments generally increased the saturation ratio by up to 0.3 (Knopf and Koop, 2006; Cziczo et al., 2009a; Eastwood et al., 2009; Sullivan et al., 2010b; Chernoff and Bertram, 2010), with three exceptions: Unlike in the experiments with ATD, Cziczo et al. (2009a) observed nearly identical nucleation onset saturation ratios for uncoated, sulfuric acid coated and ammonium sulfate coated illite particles (but slightly lower temperatures for the coated particles, not shown). Sullivan et al. (2010a) found suppression of deposition nucleation by nitric acid coatings on the nucleation ability of ATD particles, but no apparent effect above water saturation. At one out of five investigated temperatures, also Knopf and Koop (2006) observed an increase in the nucleation ability of sulfuric acid coated ATD particles. Salam et al. (2007) observed an increase of the ice nucleation efficiency of montmorillonite particles after ammonia gas exposure.

Regarding the transferabilty of these results to atmospheric conditions, the coating mechanism (in some cases involving heating of the sample), the trace gas concentrations and the actual fraction of coated particles in the cited studies have to be critically evaluated.

\section{Determining factors of ice nucleation efficiency}

\subsection{Surface area dependence}

It was shown in the previous section that supermicron dust particles tend to nucleate ice at higher temperatures and lower supersaturations over ice than smaller ones. This effect will be investigated and quantified in this section. 
Table 6. Laboratory experiments with mineral dust, soot and other particles with coatings/surface treatments or in aqueous solutions.

\begin{tabular}{|c|c|c|c|c|c|}
\hline Reference & material & $\begin{array}{l}\text { type of instru- } \\
\text { ment }\end{array}$ & $\begin{array}{l}\text { name of instru- } \\
\text { ment or institu- } \\
\text { tion }\end{array}$ & nucleation mode & coating/surface treatment \\
\hline Attard et al. (2012) & Pseudomonas bacteria & DFA & UBP & immersion & $\mathrm{NO}_{2}, \mathrm{O}_{3}$ and UV-A \\
\hline Chernoff and Bertram (2010) & $\begin{array}{l}\text { illite, montmorillonite, } \\
\text { quartz, Snomax }\end{array}$ & CS-FDC & UBC & deposition & $\mathrm{H}_{2} \mathrm{SO}_{4}$ and $\mathrm{NH}_{4} \mathrm{HSO}_{4}$ \\
\hline Chou et al. (2012) & soot & CFDC-P & PINC & deposition/condensation & photochemical aging \\
\hline Cziczo et al. (2009a) & ATD & CECC & AIDA & deposition & ammonium sulfate, sulfuric acid \\
\hline DeMott et al. (1999) & soot & CFDC-C & CSU & deposition & sulfuric acid \\
\hline Dymarska et al. (2006) & lamp black soot & CS-FDC & UBC & deposition & ozone \\
\hline Eastwood et al. (2009) & kaolinite & CS-FDC & UBC & deposition & $\mathrm{H}_{2} \mathrm{SO}_{4}$ and $\left(\mathrm{NH}_{4}\right)_{2} \mathrm{SO}_{4}$ \\
\hline Hung et al. (2003) & $\begin{array}{l}\text { hematite and } \\
\text { corundum }\end{array}$ & AFT & Harvard & immersion & aqueous ammonium sulfate \\
\hline Knopf and Koop (2006) & ATD & CS-FDC & ETHZ & deposition & sulfuric acid \\
\hline Koop and Zobrist (2009) & ATD and Snomax ${ }^{\mathrm{TM}}$ & DSC & $\begin{array}{l}\text { UBielefeld/ } \\
\text { ETHZ }\end{array}$ & immersion & $\begin{array}{l}\text { ammonium sulfate, sulfuric acid, glu- } \\
\text { cose, polyethylene glycol }\end{array}$ \\
\hline Koehler et al. (2010) & ATD & CFDC-C & $\mathrm{CSU}$ & $\begin{array}{l}\text { deposition and } \\
\text { condensation }\end{array}$ & SOA \\
\hline Möhler et al. (2005a) & soot & CECC & AIDA & deposition & sulfuric acid \\
\hline Möhler et al. (2008a) & ATD and illite & CECC & AIDA & deposition & SOA \\
\hline Niedermeier et al. (2010) & ATD & LFT & LACIS & immersion & $\begin{array}{l}\text { ammonium sulfate, sulfuric acid and } \\
\text { succinic acid }\end{array}$ \\
\hline Niedermeier et al. (2011a) & ATD & LFT & LACIS & immersion & $\begin{array}{l}\text { sulfuric acid and } \\
\text { sulfuric acid + ammonia }\end{array}$ \\
\hline Reitz et al. (2011) & ATD & LFT & LACIS & immersion & $\begin{array}{l}\text { sulfuric acid and } \\
\text { sulfuric acid + ammonia }\end{array}$ \\
\hline Salam et al. (2007) & montmorillonite & CFDC-C & UDalhousie & deposition & ammonia gas exposure \\
\hline Sullivan et al. (2010b) & ATD & CFDC-C & $\mathrm{CSU}$ & $\begin{array}{l}\text { deposition and } \\
\text { condensation }\end{array}$ & $\begin{array}{l}\text { sulfuric acid and } \\
\text { sulfuric acid }+ \text { ammonia }\end{array}$ \\
\hline Sullivan et al. (2010a) & ATD & CFDC-C & CSU & $\begin{array}{l}\text { deposition and } \\
\text { condensation }\end{array}$ & nitric acid gas exposure \\
\hline Wang and Knopf (2011) & humic-like substances & CS-FDC & $\begin{array}{l}\text { Stony } \\
\text { Brook U }\end{array}$ & deposition & ozone \\
\hline Zobrist et al. (2008) & ATD & DSC & ETHZ & immersion & ammonium sulfate \\
\hline Zuberi et al. (2002) & $\begin{array}{l}\text { kaolinite and montmoril- } \\
\text { lonite }\end{array}$ & $\mathrm{CS}$ & MIT & immersion & aqueous ammonium sulfate \\
\hline
\end{tabular}

Heterogeneous ice nucleation is occuring at the surface of solid aerosol particles. Although the exact mechanism is still obscure, several surface-related requirements have been suggested for efficient IN: the chemical bond requirement, the crystallographic requirement, and the active-site requirement (Pruppacher and Klett, 1997). The larger the surface area of an aerosol particle, the higher is the probability that some part of its non-uniform surface fulfils the necessary requirement for nucleation. Also in classical nucleation theory, which in its simplest form assumes uniform surfaces, the nucleation rate is proportional to the surface area, because nucleation is assumed to occur stochastically with the same probability everywhere on the uniform surface (Fletcher, 1958).

As a simplified quantification of the aerosol size effect on the observed IN fractions and nucleation onsets, the metric of "ice nucleation active surface site (INAS) densi- ties" is employed in the following (DeMott, 1995; Connolly et al., 2009). The INAS density describes the number of icenucleation active sites at a certain temperature and supersaturation, normalized by the aerosol surface area. The approach is based on the assumption that the investigated aerosol sample is of uniform composition. Time dependence is not taken into account. In the following, the INAS density $n_{\mathrm{S}}$ (averaged over the investigated sample) is calculated from the following equation:

$$
\begin{aligned}
n_{\mathrm{s}}\left(T, S_{\mathrm{i}}\right) & =-1 / A_{\mathrm{aer}} \cdot \ln \left(1-f_{\mathrm{IN}}\left(T, S_{\mathrm{i}}\right)\right) \\
& \approx f_{\mathrm{IN}}\left(T, S_{\mathrm{i}}\right) / A_{\text {aer }}
\end{aligned}
$$

In this expression, $f_{\mathrm{IN}}$ is the ice nucleation active fraction under the considered conditions, and $A_{\text {aer }}$ is the aerosol surface per particle. The approximation is valid for small values of $f_{\mathrm{IN}}$. Under the assumption of a constant INAS density independent of size, Eq. (1) can also be applied to polydisperse 


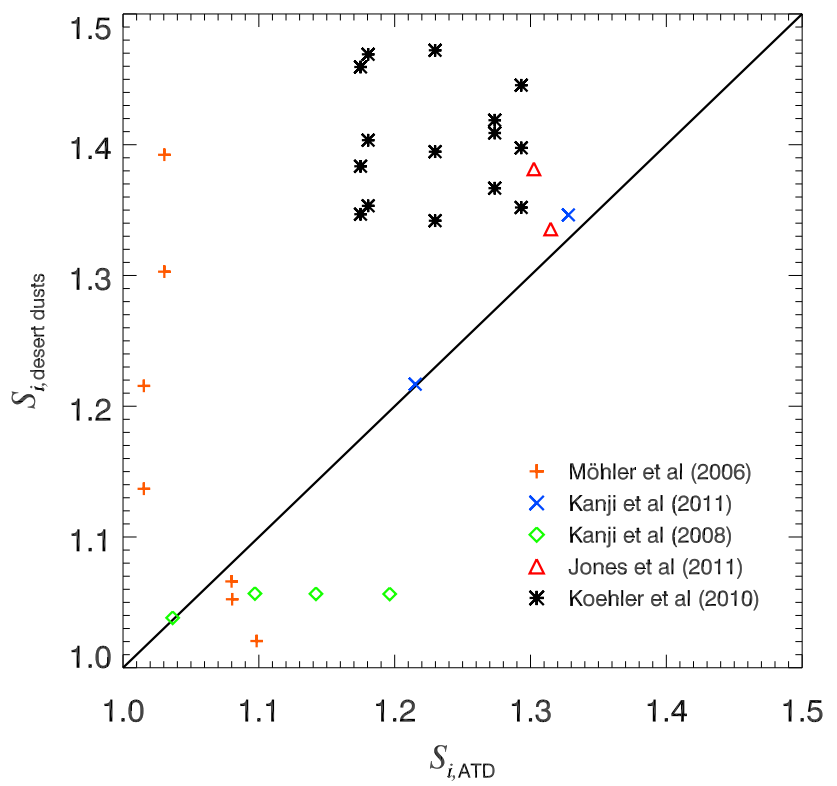

Fig. 8. Saturation ratios at nucleation onset for Arizona test dust and natural desert dusts (Saharan, Asian, Canary Island and Owens Lake dust) under comparable experimental conditions and interpolated to the same temperatures, respectively. The data by Koehler et al. (2010) are for dry dispersed particles of $200 \mathrm{~nm}$ size. The data by Kanji et al. (2011) are for UT-CFDC measurements sampled from the aerosol preparation and characterization chamber for ATD and Canary Island dust, which have similar size distributions. The data by Kanji et al. (2008) are interpolated to the same total particle surface areas. The data by Jones et al. (2011) are from the CSU-CFDC instrument and for water-subsaturated conditions.

particles, with $A_{\text {aer }}$ obtained from the total aerosol surface area concentration divided by the total aerosol number concentration.

$n_{\mathrm{S}}$ has previously been used to quantify the nucleation ability of mineral dusts (Connolly et al., 2009; Niedermeier et al., 2010; Broadley et al., 2012; Niemand et al., 2012), volcanic ash (Bingemer et al., 2011; Steinke et al., 2011), and marine diatoms (Alpert et al., 2011a). Figure 10 illustrates the corresponding ice nucleation active fractions for a given INAS density and particle size.

In the following, Eq. (1) is applied to the previously discussed ice nucleation data (where possible). The data shown here are calculated based on the information available in the cited publications, except for cases in which $n_{\mathrm{s}}$ was provided directly (Connolly et al., 2009; Niedermeier et al., 2010; Murray et al., 2011; Broadley et al., 2012; Niemand et al., 2012). Where the ice nucleation active fraction $f_{\mathrm{IN}}$ was given as a range of values (e.g. an onset corresponding to 0.1 to $1 \%$ ), this range is converted into a range of $n_{\mathrm{s}}$. In the case of Pinti et al. (2012), frozen fractions of $0.1 \%$ to $2.6 \%$ (V. Pinti, personal communication, 2012) were assumed for the freezing onset in the emulsion experiments, and a frozen fraction of 1 for the bulk experiments. For the aerosol surface area

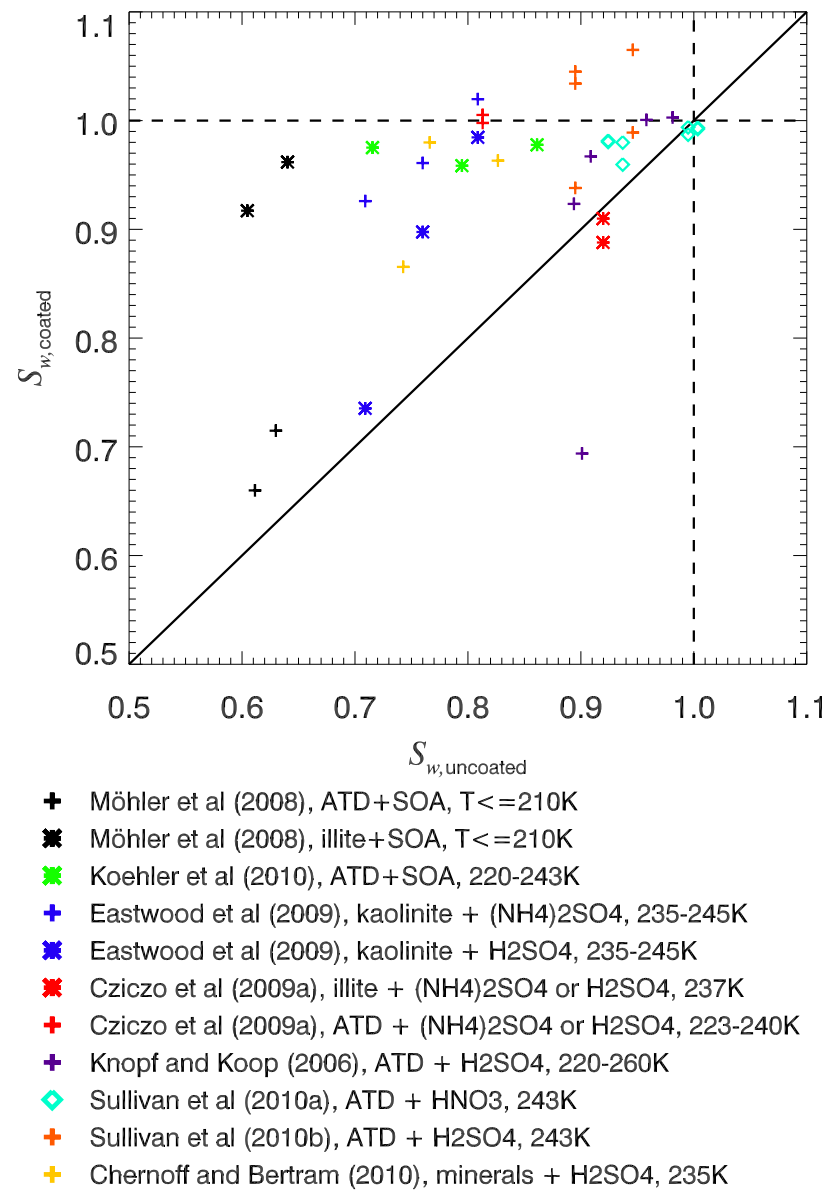

Fig. 9. Effect of different coatings on supersaturation with respect to water required to activate a specific fraction of IN in experiments at the temperatures given in the legend.

$A_{\text {aer }}$, an estimate based on the information given in the original publication is associated with large uncertainties, in particular for polydisperse particles. In most cases, we had to estimate $A_{\text {aer }}$ from the reported average size $d$ by $A_{\text {aer }}=\pi d^{2}$. This approach neglects any deviations when the reported size is the mobility diameter instead of the geometric diameter (Welti et al., 2009; Koehler et al., 2010) or when the distribution has a large spread (Wang and Knopf, 2011). Where a range of sizes is given instead of an average size (Knopf and Koop, 2006; Zimmermann et al., 2008), we proceed as with the case of a range of $f_{\mathrm{IN}}$ values.

\subsubsection{Immersion/condensation freezing}

Figures 11 to 13 display $n_{\mathrm{S}}$ for immersion/condensation freezing. ATD, desert dusts, three clay minerals, soot and bioaerosol data are examined separately. The data stem either from immersion freezing experiments with suspensions (e.g., Murray et al., 2011), from experiments in which the investigated aerosol particles are first activated as $\mathrm{CCN}$ 

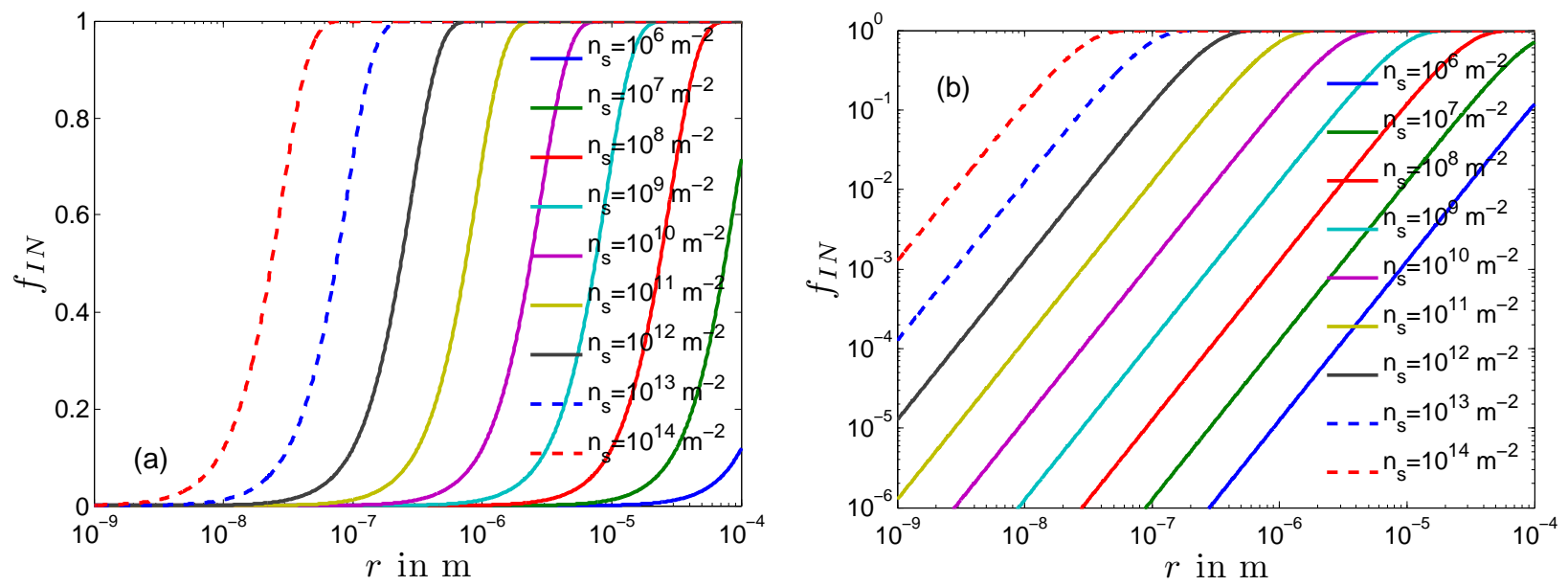

Fig. 10. Activated fraction as a function of aerosol radius for values of different INAS densitites. (b) is identical to (a) except that the $y$-axis is spaced logarithmically.

(a) ATD

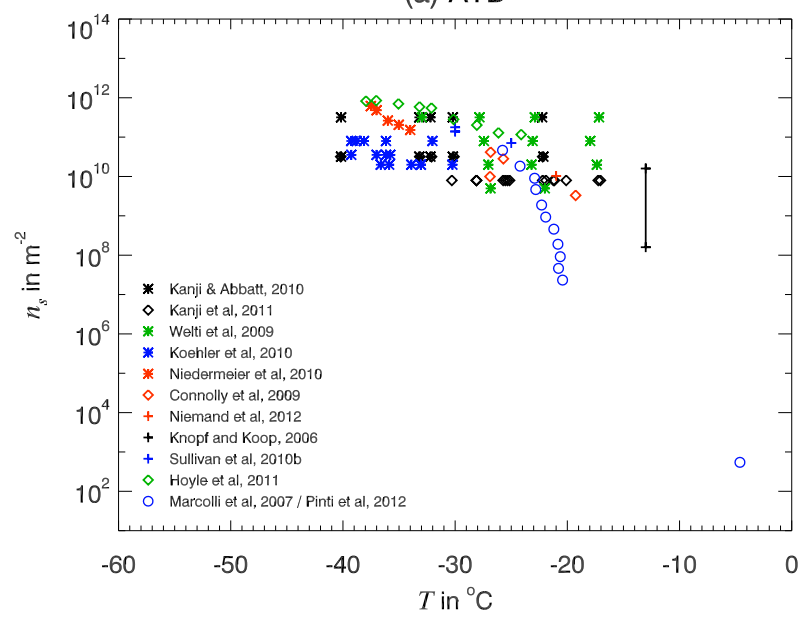

(c) kaolinite

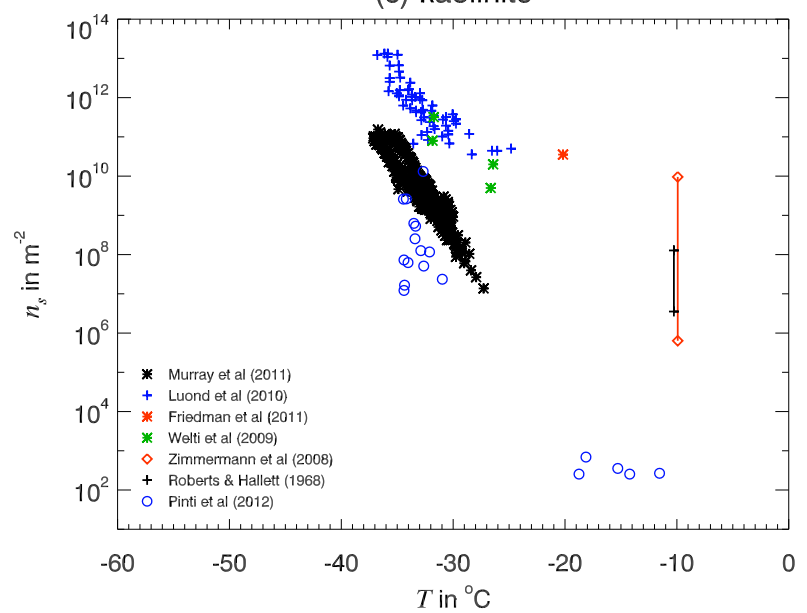

(b) desert dusts

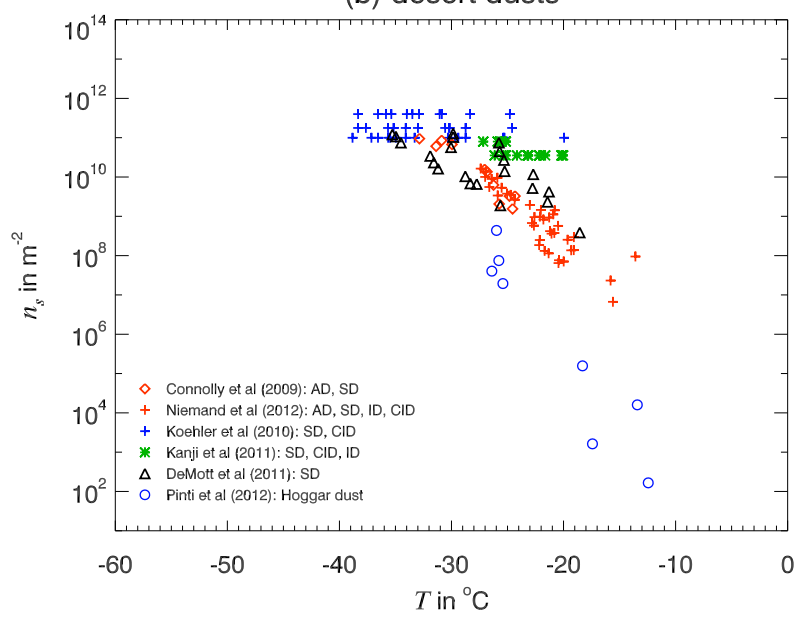

(d) montmorillonite and illite

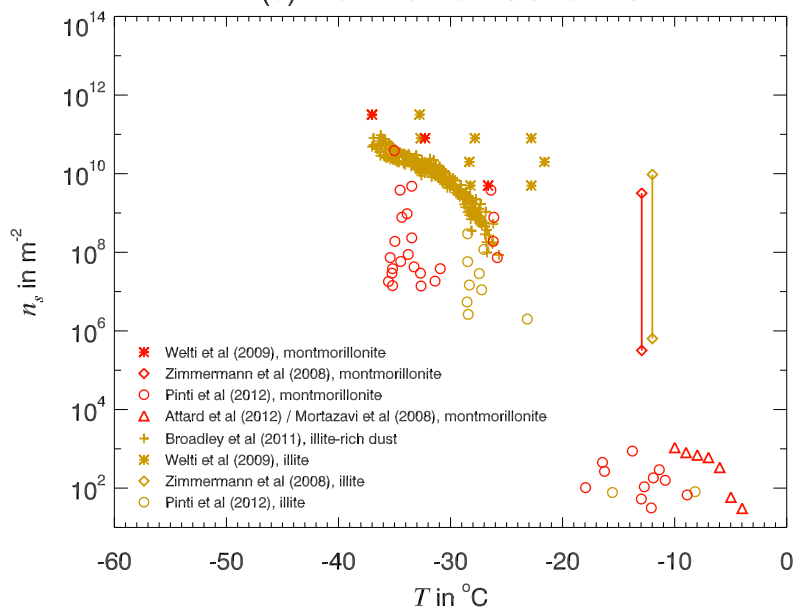

Fig. 11. INAS densities for ATD, natural desert dusts and different clay minerals for immersion freezing, including deposition/condensation freezing experiments at or above water saturation. The INAS densities are derived either by assuming spherical particles or with BET surface areas (Murray et al., 2011; Broadley et al., 2012; Pinti et al., 2012; Attard et al., 2012). The data by Connolly et al. (2009) have been corrected by a factor of 10 as described in Niemand et al. (2012). 


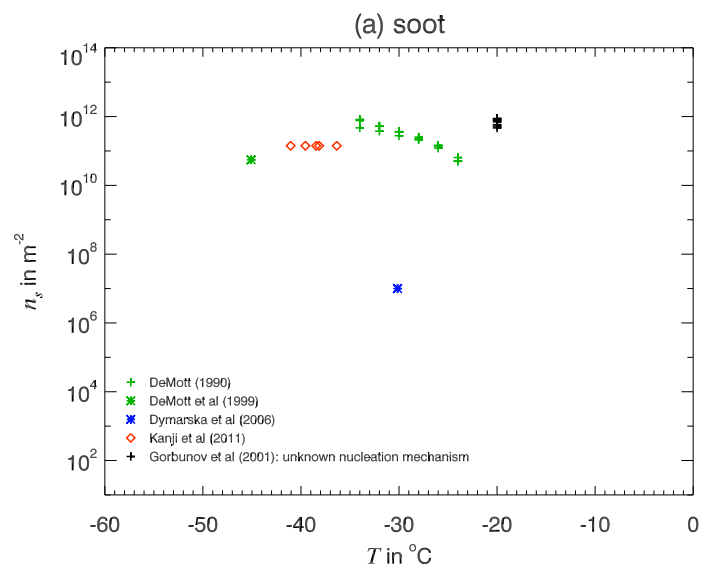

(b) bacteria
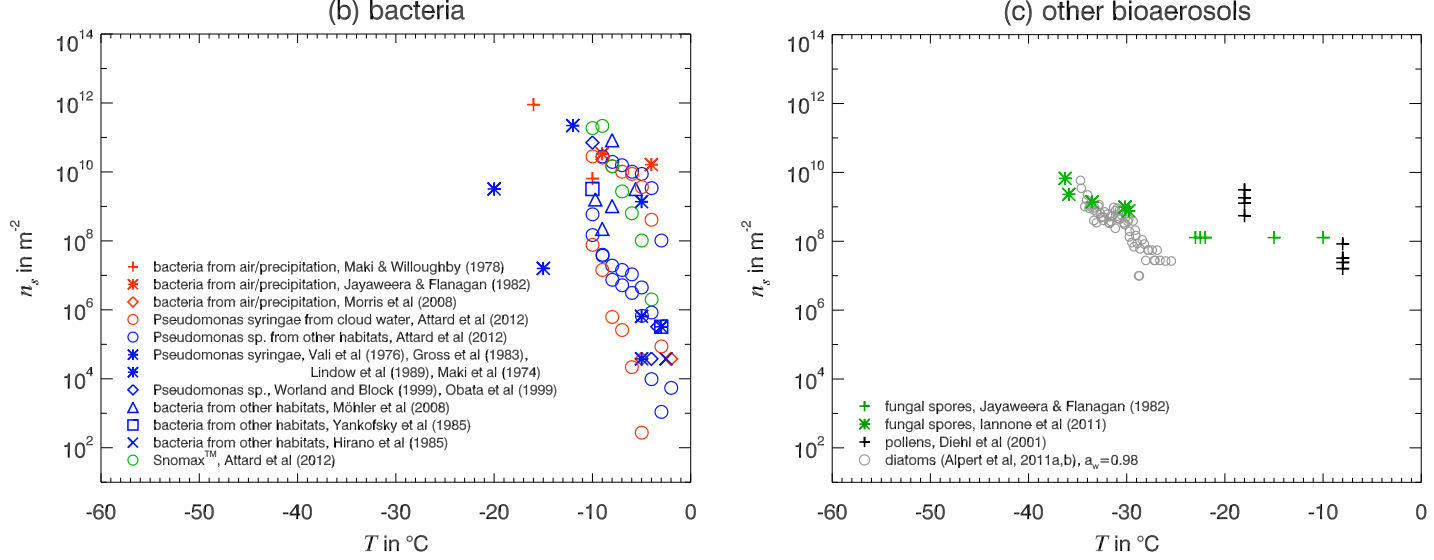

Fig. 12. INAS densities for soot and bioaerosols for immersion freezing, including deposition/condensation freezing experiments at or above water saturation.

and subsequently exposed to low temperatures (e.g., Lüönd et al., 2010; Niedermeier et al., 2010), or from experiments in water-supersaturated conditions (e.g., Kanji and Abbatt, 2006; Koehler et al., 2010). For the latter, we assume that condensation occurred before ice formation, even though the intermediate liquid phase could not be explicitly detected. This assumption is corroborated by a comparison to flow tube experiments (Niedermeier et al., 2011a). In CFDCs, the activated fraction at a given temperature increases further when the relative humidity is increased to several percent above water saturation, possibly because of the dilution of impurities on the particles surfaces in larger droplets (DeMott et al., 2011). This can explain some of the spread in the data discussed below.

In a number of individual studies for different mineral dusts (Connolly et al., 2009; Niedermeier et al., 2010; Murray et al., 2011b), a steep increase of INAS densities with decreasing temperatures was reported. This general feature is also visible in the compilation of data from various sources for ATD, desert dusts and clay minerals (Fig. 11a-d). In particular, it is revealed that the high nucleation onset temperatures for relatively large particles measured by Knopf and Koop (2006), Zimmermann et al. (2008) and Roberts and
Hallett (1968) are actually consistent with most of the results at lower temperatures, which were obtained with smaller particles. For example, the kaolinite data from Zimmermann et al. (2008) and Roberts and Hallett (1968) at about $-10^{\circ} \mathrm{C}$ fall in line with an extrapolation of the data by Lüönd et al. (2010), which cover the temperature range between -25 and $-36^{\circ} \mathrm{C}$. Some of the assumed condensation freezing events in CFDCs (Welti et al., 2009; Koehler et al., 2010; Kanji et al., 2011) appear to exhibit a less clear temperature dependence of the estimated INAS densities (Fig. 11a, b), because based on the available data, these could only be derived for selected activated fractions.

Comparing the results for the three dust types, it is found that the values of the INAS densities for ATD and natural dusts largely overlap, with a slope of about a factor of $10 \mathrm{in}$ crease in $n_{\mathrm{s}}$ per temperature decrease of $10 \mathrm{~K}$ and a spread of about two orders of magnitude at a given temperature. For kaolinite, two experiments indicate a steeper slope of about a factor of $100-1000$ increase in $n_{\mathrm{s}}$ per temperature decrease of $10 \mathrm{~K}$ (Lüönd et al., 2010; Murray et al., 2011). In addition, the data obtained by Murray et al. (2011) and Pinti et al. (2012) are markedly lower than the other estimates of $n_{\mathrm{s}}$. It should be noted that Murray et al. (2011), 


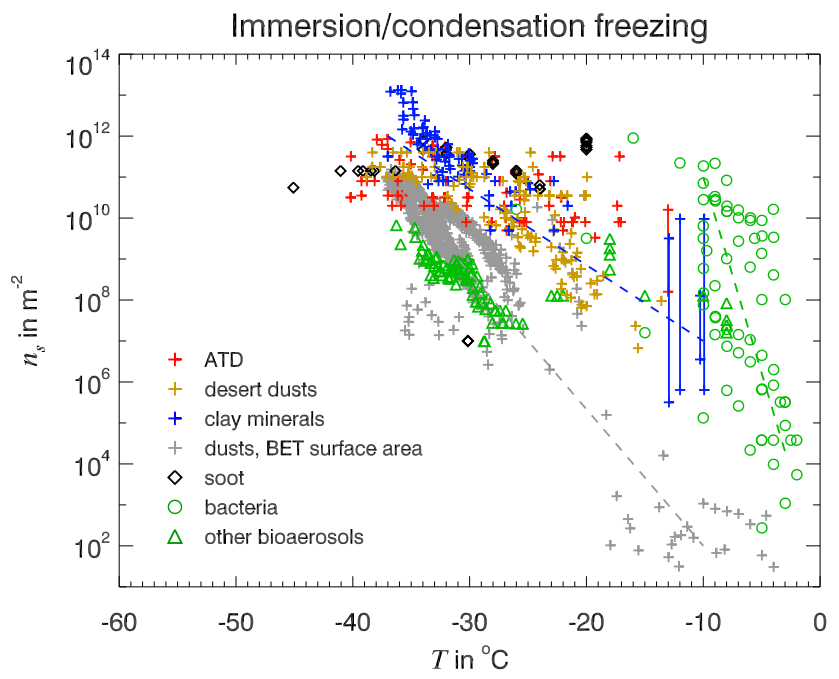

Fig. 13. INAS densities for ATD, kaolinite, natural desert dusts, soot and bioaerosols for immersion freezing, including deposition/condensation freezing experiments at or above water saturation. The data sources are the same as in Figs. 11 and 12. The lines are inserted to guide the eye. The blue line refers to both ATD, desert dusts and clay minerals. The green line refers to highly INA biological aerosols.

Broadley et al. (2012) and Pinti et al. (2012) used values of the specific surface area determined by BET (Brunauer, Emmett and Teller gas adsorption technique, Brunauer et al., 1938). This method is expected to yield higher surface areas than our simplified assumption of spherical dust particles, because surface irregularities, cracks, etc. contribute to the surface area measured by BET, which then results in a lower value of $n_{\mathrm{s}}$. Furthermore, impurities in the dust samples and physical or chemical processing can be a source of the observed discrepancies, as discussed in Sect. 3.2. Finally, it is also possible that different size sections of the investigated samples exhibit different ice nucleation properties.

For soot (Fig. 12a), there is a vast disparity between the INAS densities derived from different experiments. The only true immersion freezing experiment with soot (DeMott, 1990) yields values of $n_{\mathrm{s}}$ comparable to mineral dust, and similar results are found by Kanji et al. (2011) above water saturation. By contrast, on the one hand, the INAS density calculated from values given in Dymarska et al. (2006) for one experiment in which ice formation was observed above water saturation, but without indication of liquid droplet formation prior to ice nucleation, are significantly lower. On the other hand, Gorbunov et al. (2001) measured relatively high activated fractions for soot particles already at $-20^{\circ} \mathrm{C}$ which translate into INAS densities higher than those for mineral dust. It should also be noted that soot particles are often fractal-like agglomerates for which the simple assumption of spherical particles may lead to a large error in the calculated INAS density.
The results for bioaerosols (Fig. 12b) are particularly interesting, because the ice nucleation onset is often reported for a very small activated fraction $f_{\mathrm{IN}}$, e.g. $10^{-6}$ (see also overview in Després et al., 2012). In addition, most primary biological particles belong to the coarse mode aerosol. For the calculation of $n_{\mathrm{s}}$, generic values for the particle diameters were assumed in the absence of better information: $1 \mu \mathrm{m}$ for bacteria, $5 \mu \mathrm{m}$ for fungal spores, and $20 \mu \mathrm{m}$ for pollen grains. Due to the small activated fractions and rather larger particle diameters, for a number of experiments with ice nucleation onsets above $-5^{\circ} \mathrm{C}$, very small values of $n_{\mathrm{S}}\left(10^{4}\right.$ to $\left.10^{6} \mathrm{~m}^{-2}\right)$ are estimated. For pollen, fungal spores and diatoms, $n_{\mathrm{s}}$ remains smaller than $10^{10} \mathrm{~m}^{-2}$ even at the lowest investigated temperatures.

A second group of data points for bioaerosol immersion freezing indicates significantly higher INAS densities than the other investigated particle types. This group consists of INA bacteria such as some Pseudomonas syringae strains, for which INAS densities $>10^{10} \mathrm{~m}^{-2}$ are reached already at temperatures above $-10^{\circ} \mathrm{C}$. For mineral dust, these values are typically reached only below $-20^{\circ} \mathrm{C}$.

Taking all immersion/condensation freezing INAS densities together (Fig. 13), a typical range of values for average mineral dust particles can be identified (indicated by the blue line in the plot). These range from $10^{6}-10^{8} \mathrm{~m}^{-2}$ at $-10^{\circ} \mathrm{C}$ to $10^{10}-10^{12} \mathrm{~m}^{-2}$ close to $-35^{\circ} \mathrm{C}$, i.e. roughly increasing by one order of magnitude per cooling of $5 \mathrm{~K}$. Also some of the non-bacterial biological particles exhibit INAS densities in this range. The much steeper increase of INAS densities at higher temperatures for the most active INA bacteria is indicated with the green dashed line.

The INAS density for dust and biological particles does not necessarily retain this steady increase at decreasing temperatures (although a number of experiments with one aerosol type found similar exponential temperature dependencies of $n_{\mathrm{s}}$, Niedermeier et al., 2010; Murray et al., 2011). In particular, it has been observed that $n_{\mathrm{s}}(T)$ for INA bacteria levels off at temperatures lower than $-10^{\circ} \mathrm{C}$ (Govindarajan and Lindow, 1988; Ward and DeMott, 1989). Furthermore, it should be noted that several measurements show large deviations from the average values of $n_{\mathrm{s}}(T)$, and that a difference by one or two orders of magnitudes has a large impact if applied for the calculation of atmospheric IN concentrations.

\subsubsection{Deposition nucleation}

Similar to the above analysis for immersion/condensation freezing, we apply the calculation of $n_{\mathrm{s}}$ to deposition nucleation experiments in the following. For deposition nucleation, $n_{\mathrm{s}}$ depends on both $S_{\mathrm{i}}$ and (though weaker) on $T$. Here, the data are binned into intervals of $10 \mathrm{~K}$ and shown as a function of $S_{\mathrm{i}}$ (Figs. 14 and 15). Due to a limited number of experiments which provide the necessary information, this could only be done for ATD, kaolinite and desert dusts. Again, the normalization of the ice nucleation onsets by the 


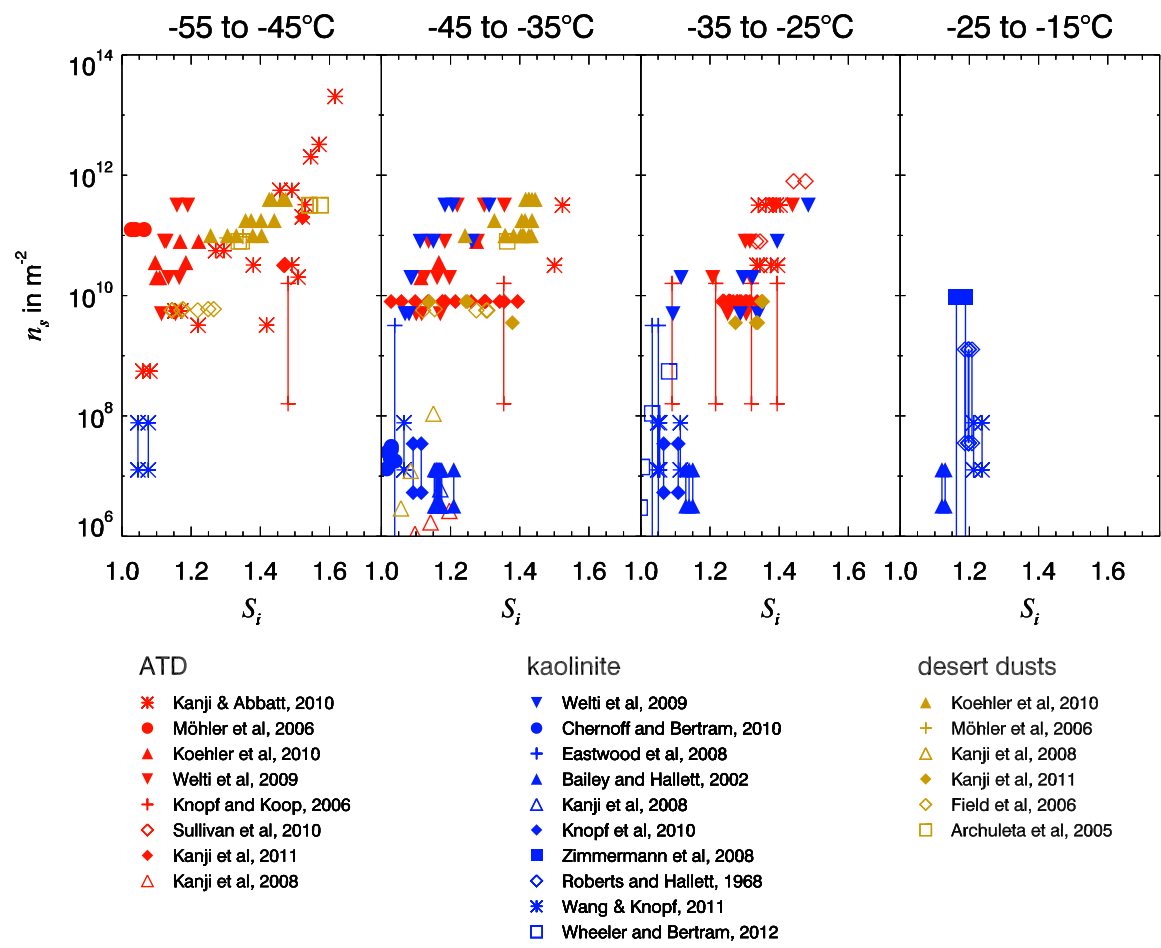

Fig. 14. INAS densities for ATD, kaolinite and desert dusts for deposition nucleation.

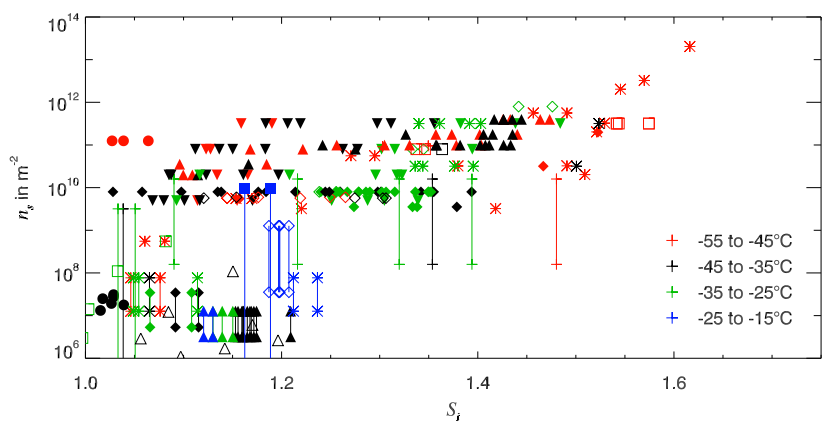

Fig. 15. INAS densities for ATD, kaolinite and desert dusts for deposition nucleation, binned into temperature intervals. The symbols and data sources are the same as in Fig. 14.

activated fraction and surface area tends to reveal a better agreement between different experiments than the nucleation onset data, but the spread remains large. Within each temperature bin, $n_{\mathrm{s}}$ increases steeply with increasing $S_{\mathrm{i}}$. In Fig. 14, where all estimates of $n_{\mathrm{s}}$ for the different minerals are shown together, no clear differences between the three mineral dusts are visible. The absolute values of $n_{\mathrm{s}}$ range mostly between $10^{6}-10^{12} \mathrm{~m}^{-2}$, i.e. similar to those for immersion freezing. In Fig. 15, the four selected temperature intervals are plotted together. The expected signal of increasing $n_{\mathrm{S}}$ with decreasing $T$ at a given supersaturation is not visible in this representation. Instead, this figure clearly illustrates the vast spread of INAS densities at low supersaturations, which is larger than the experimental uncertainties and probably related to systematic differences between different methods, and/or to individual particle or material characteristics.

\subsubsection{Contact nucleation}

Early contact ice nucleation experiments (Pitter and Pruppacher, 1973; Levin and Yankofsky, 1983; Diehl et al., 2002), in which supercooled droplets were held suspended in a flow of aerosols particles, report higher ice nucleation onsets and median freezing temperatures in the contact nucleation mode than in the immersion freezing mode. Durant and Shaw (2005) observed an increase in ice nucleation temperatures even when a particles immersed in a droplet contacted the droplet surface (termed "contact nucleation insideout"). These phenomena are not yet satisfactorily explained. Recent studies of contact nucleation (Svensson et al., 2009; Rzesanke et al., 2011; Ladino et al., 2011; Bunker et al., 2012) try to quantify the number of collision events by auxiliary measurements or theoretical calculations and to report freezing efficiencies per collision event. In some cases, the calculated freezing efficiencies are larger than 1 , pointing at deficiencies in the calculation of the collision rates and/or to measurement uncertainties. The role of particle size for contact nucleation is not clear yet: While Rzesanke et al. (2011) find a clear increase of the contact freezing efficiency with particle size, this effect is not observed or much weaker in the studies by Ladino et al. (2011) and Bunker et al. (2012). 


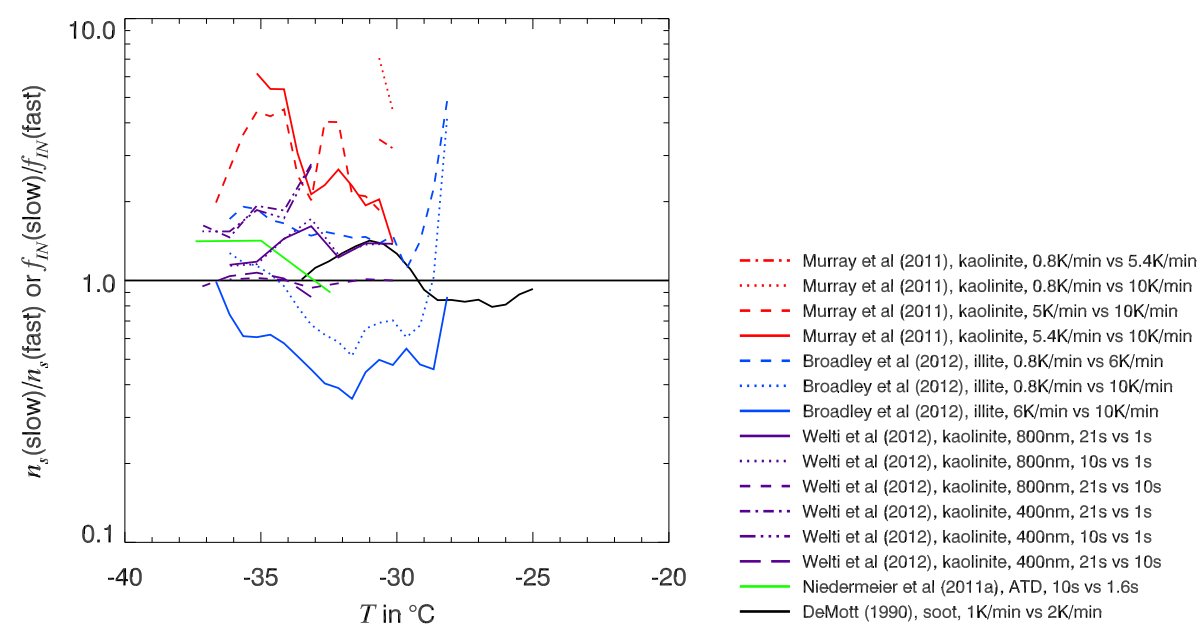

Fig. 16. Ratio of INAS densities or ice fractions in experiments with different cooling rates or residence times, but the same aerosol. The data from Murray et al. (2011), their Fig. 6a, and Broadley et al. (2012), their Fig. 6b, are binned into intervals of $0.5 \mathrm{~K}$ and compared for overlapping temperature ranges. For Broadley et al. (2012), the experiments with cooling rates of $7.5 \mathrm{~K} \mathrm{~min}^{-1}, 5 \mathrm{~K} \mathrm{~min}^{-1}$ and $1 \mathrm{~K} \mathrm{~min}^{-1}$ are not included here because of the large spread in the data. The data shown from Niedermeier et al. (2011b) represent the three data points for which experiments with a nucleation time of $10 \mathrm{~s}$ were conducted (their Fig. 1). For soot, two experiments with $0.08 \mu \mathrm{m}$ particles are compared (DeMott, 1990, his Fig. 5).
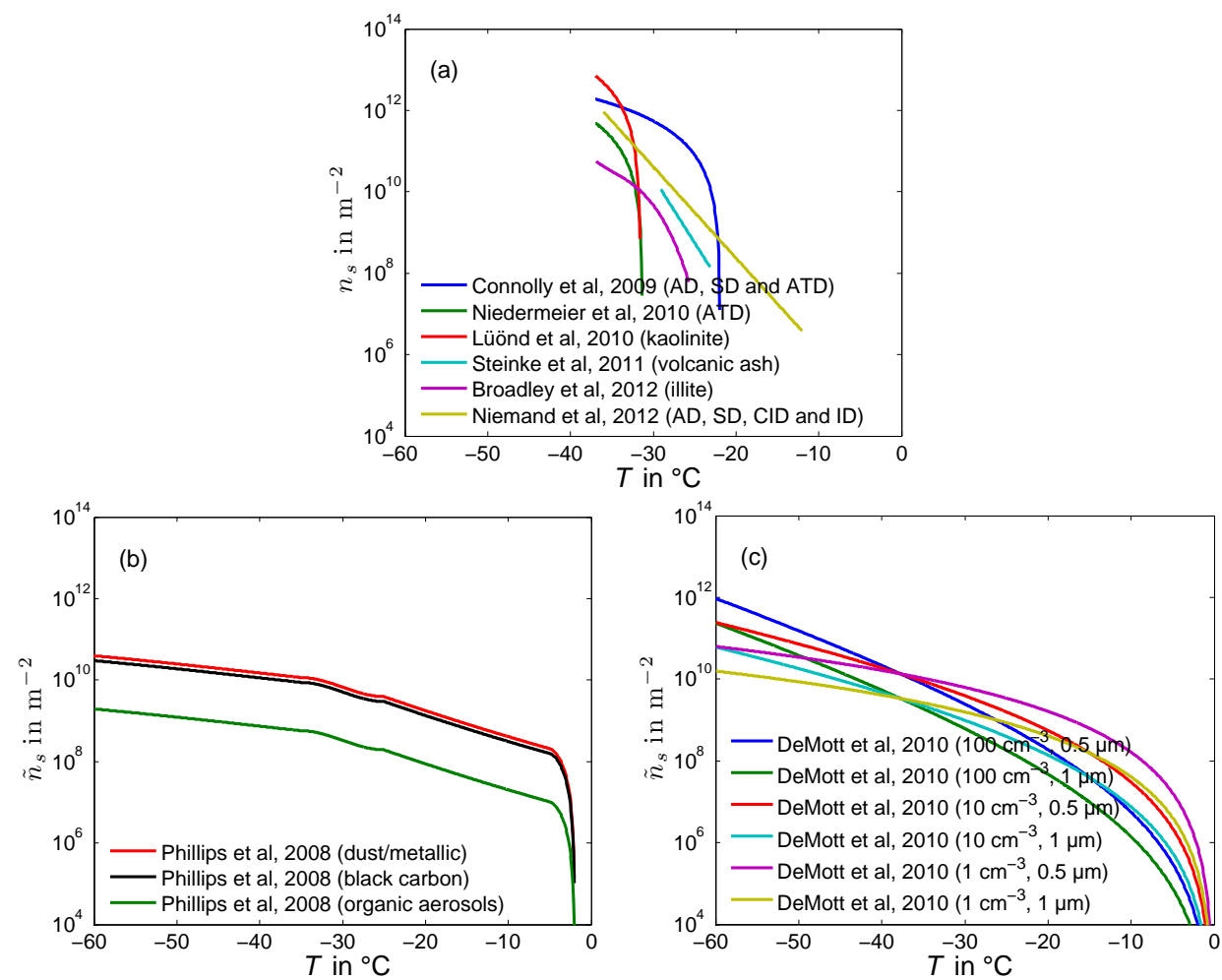

Fig. 17. (a) Parameterizations of $n_{\mathrm{S}}$ for immersion freezing. (b) Equivalent $\tilde{n}_{S}$ from Phillips et al. (2008) evaluated at water saturation. (c) Equivalent $\tilde{n}_{s}$ derived from DeMott et al. (2010) for different concentrations and monodisperse particles.

\subsection{Observed time dependence}

With the description of ice nucleation as a stochastic process, an increase of the activated particle fraction with longer measurement times is expected. This time dependence can only be resolved if a large number of particles within the sample exhibits the same ice nucleation probability at a given $T$ and $S_{\mathrm{i}}$. For the CFDC-type and mixing cloud 

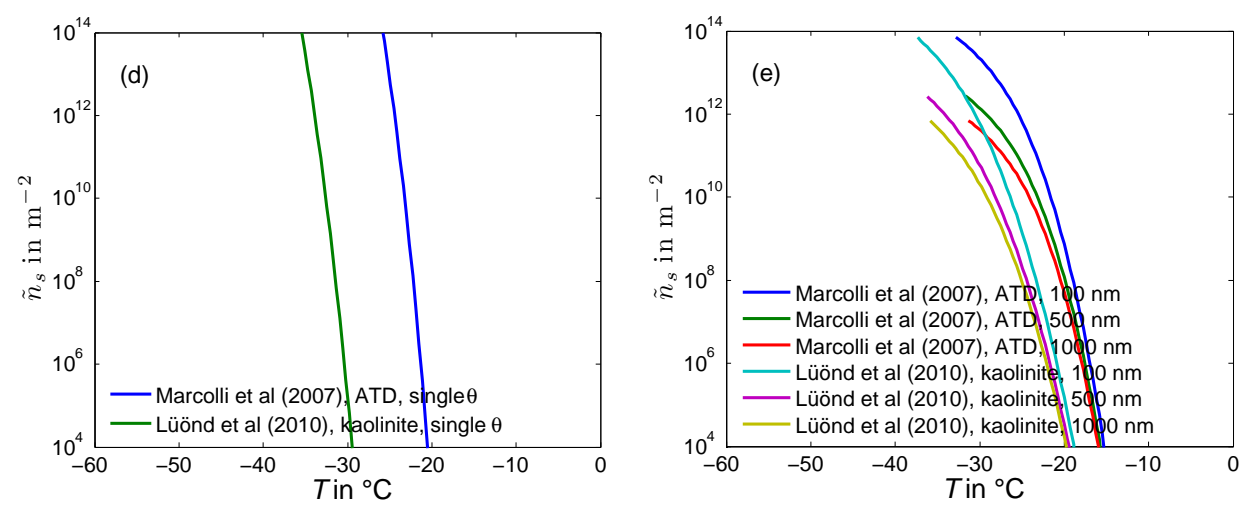

Fig. 18. (d) Apparent $\tilde{n}_{S}$ from CNT (as formulated by Zobrist et al. (2007)) with single contact angles, fitted by Marcolli et al. (2007) and Lüönd et al. (2010). (e) Apparent $\tilde{n}_{s}$ from CNT with a distribution of contact angles, with parameters fitted by Marcolli et al. (2007) and Lüönd et al. (2010), for different particle sizes.

chamber experiments listed in Tables 1 to 6 , which all operate at fixed temperature and relative humidity, the residence time varies between $1.6 \mathrm{~s}$ and $120 \mathrm{~s}$. Similarly, in the experiments with decreasing temperatures and/or increasing relative humidities during the measurement, the inverse cooling rates vary from $6 \mathrm{~s}$ to $600 \mathrm{~s}$ per $\mathrm{K}$ and/or per $\%$ increase in relative humidity.

The time dependence in the analysis of literature data (comparable to Sect. 4.1), can be investigated for experiments at constant conditions via an estimation of the nucleation rate coefficient:

$j_{\text {het }}\left(T, S_{\mathrm{i}}\right) \approx \frac{f_{\mathrm{IN}}\left(T, S_{\mathrm{i}}\right)}{A_{\text {aer }} \Delta t}$

$\Delta t$ is the time for which the aerosol is exposed to the temperature $T$ and the supersaturation $S_{\mathrm{i}}$. For experiments at water saturation with a constant cooling, the nucleation rate coefficient can be determined incrementally from

$$
\begin{aligned}
f_{\mathrm{IN}}(T) & \approx A_{\text {aer }} \int j_{\text {het }}(T(t)) \mathrm{d} t \\
& =A_{\text {aer }} \int j_{\text {het }}(T(t))\left(\frac{\mathrm{d} T}{\mathrm{~d} t}\right)^{-1} \mathrm{~d} T
\end{aligned}
$$

This leads to

$j_{\text {het }}(T) \approx \frac{1}{A_{\text {aer }}} \frac{\mathrm{d} f_{\mathrm{IN}}}{\mathrm{d} T} \frac{\mathrm{d} T}{\mathrm{~d} t}$

For the immersion freezing data in Fig. 13, such an analysis did not yield a better agreement between different experiments (not shown). For example, for ATD, $\Delta t$ is similar for Kanji et al. (2011) and Hoyle et al. (2011), but both $j_{\text {het }}$ and $n_{\mathrm{S}}$ differ by more than a factor of 10 .

In extensive early studies (Vali and Stansbury, 1966; Vali, 1994, 2008), it was shown that immersion freezing exhibits time-dependence, but that the observed time dependence is weaker than expected from classical nucleation theory (see
Appendix A1). Recently, further in-depth analyses of the influence of time on the activated fraction were conducted by Murray et al. (2011), Broadley et al. (2012) and Welti et al. (2012). In their experiments, the cooling rate or residence times could be varied by more than a factor of 10 . Their results are summarized in Fig. 16, along with two experiments by Niedermeier et al. (2011b) and DeMott (1990). While Murray et al. (2011)'s and Welti et al. (2012)'s results indicate significantly more ice nucleation in experiments with slower cooling rates, the other studies do not confirm this behaviour and instead show sometimes more, sometimes less ice nucleation when more time is available for freezing. It should also be noted that the spread in the data entering these calculations is large. For none of the experiments, the ratio of ice fraction or INAS densities in the slow versus fast experiments converges towards the ratio of the cooling rates or residence times, as would be expected if nucleation was described well by a temperature-dependent nucleation rate with one value for all particles. Nevertheless, Murray et al. (2011) found that such a single component stochastic model fits their data best, in particular if constant-temperature experiments are considered. Welti et al. (2012) could best fit their results with a distribution of contact angles.

\section{Parametrical descriptions}

In this section, we attempt to present various ice nucleation parameterizations using similar metrics as the measurements, in order to allow a direct comparison.

\subsection{Immersion freezing parameterizations: temperature and surface area dependence}

As discussed in Sect. 4.1, it is a well-established idea that ice nucleation propability is related to the surface area of the nucleus. Most parameterizations which link heterogeneous ice nucleation to aerosol properties assume proportionality 
to aerosol surface area. Three classes of these surface-related parameterizations for immersion freezing will be discussed in more detail below: empirical fits of INAS densities, parameterizations derived from ambient IN measurements, and parameterizations based on classical nucleation theory. A few other parameterizations assume proportionality to drop volume instead to aerosol surface area (Bigg, 1953; Diehl and Wurzler, 2004). It can be assumed that this apparent volume dependence reflects the fact that in the experiments which they are based on, the investigated droplets contained more than one aerosol particle, and thus the larger the droplets the larger the aerosol surface area included in them (Murray et al., 2011).

\subsubsection{Parameterizations of INAS densities}

Recently, empirical parameterizations for the INAS density $n_{\mathrm{S}}(T)$ for immersion freezing have been derived from laboratory experiments (Connolly et al., 2009; Niedermeier et al., 2010; Lüönd et al., 2010; Steinke et al., 2011; Broadley et al., 2012; Niemand et al., 2012). These formulations are fits to measured data for a specific aerosol type, and are a function of the temperature only (Fig. 17a). Different functional forms with two to four fit parameters have been applied, yielding varying slopes of the temperature dependence. The parameterizations by Connolly et al. (2009), Niedermeier et al. (2010) and Lüönd et al. (2010) fall off steeply at high subzero temperatures, which contradicts the overall picture in the measurements compiled in Fig. 13. Niemand et al. (2012)'s parameterization includes measurements in a wider temperature range and extends up to $-12{ }^{\circ} \mathrm{C}$.

\subsubsection{Parameterizations based on atmospheric IN measurements}

Phillips et al. (2008) presented an empirical ice nucleation parameterization based on CFDC measurements and coincident aerosol data. A reference IN profile is constructed for the complete range of subzero temperatures and saturation ratios larger than 1 . This reference IN concentration is distributed to three types of IN (dust/metallic, black carbon and organic particles) and associated with a reference aerosol concentration. The parameterization is applied to a given aerosol composition and concentration by scaling the reference IN profile with the surface area of dust/metallic, black carbon and organic aerosols.

By comparing Eqs. (9) and (10) in Phillips et al. (2008) to the definition of $n_{\mathrm{s}}$ in Sect. 4.1 , it can be seen that the following terms can be identified with an equivalent INAS density $\tilde{n}_{s}$ :

$\tilde{n}_{s, \text { Phillips }, X}=H_{X}\left(S_{\mathrm{i}}, T\right) \xi(T) \frac{\alpha_{X} n_{\mathrm{IN}, 1, *}}{\Omega_{X, 1, *}}$

Here, the index $X$ refers to dust/metallic, black carbon and organic aerosols. The variables are listed in Table A1 and in Phillips et al. (2008). In Fig. 17b, $\tilde{n}_{s}$ is displayed at water saturation for the three IN types. $\tilde{n}_{s \text {,Phillips,dust/metallic has }}$ a weaker temperature dependency than $n_{\mathrm{s}}$ calculated from experiments (Fig. 13), resulting in lower values than observed at $T<-25^{\circ} \mathrm{C}$. The values calculated for $\tilde{n}_{s, \text { Phillips,soot }}$

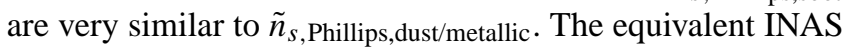
density for organic aerosols ( $\left.\tilde{n}_{s, \text { Phillips,organic aerosols }}\right)$ is about one order of magnitude lower and disagrees with most observed values for highly ice nucleation active bacteria (Fig. 13) at $T<-5^{\circ} \mathrm{C}$. The agreement is better with fungal spores, pollen and a few estimates of bacteria INAS densities at $T>-5^{\circ} \mathrm{C}$.

A different approach of parameterizing IN concentrations based on CFDC measurements was taken by DeMott et al. (2010), who related IN concentrations to temperature and the number concentration of aerosol particles with diameters larger than $0.5 \mu \mathrm{m}\left(n_{\mathrm{aer}, 05}\right)$, and found that this relationship could explain a large part of the variability in observed IN concentrations. While the relationship is not strictly proportional to aerosol surface area (nor to aerosol number concentration), we can derive equivalent INAS densities for chosen values of $n_{\mathrm{aer}, 05}$ under the assumption of a monodisperse size distribution with diameter $d$ :

$\tilde{n}_{s, \text { DeMott }}=\frac{n_{\mathrm{IN}}\left(T, n_{\mathrm{aer}, 05}\right)}{\pi d^{2} n_{\mathrm{aer}, 05}}$

Here, $n_{\mathrm{IN}}\left(T, n_{\mathrm{aer}, 05}\right)$ is parameterized after DeMott et al. (2010, their Eq. 1). $\tilde{n}_{s, \text { DeMott }}$ is shown in Fig. $17 \mathrm{c}$ for $n_{\mathrm{aer}, 05}=$ 1 to $100 \mathrm{~cm}^{-3}$ and $d=0.5$ and $1 \mu \mathrm{m}$. For small aerosol number concentrations, $\tilde{n}_{s, \text { DeMott }}$ is similar to $\tilde{n}_{s \text {, Phillips }}$, but the temperature dependency is steeper for higher aerosol

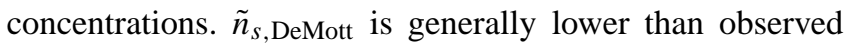
INAS densities for dust (Fig. 13), which is expected because $\tilde{n}_{s, \text { DeMott }}$ refers to an average active site density of an aerosol population including inactive particles.

\subsubsection{Parameterizations employing classical nucleation theory for immersion freezing}

In classical nucleation theory (CNT), the nucleation rate coefficient $j$ is proportional to the aerosol surface area. Some of the different formulations of classical nucleation theory which have been used to fit laboratory measurements are summarized in Appendix A1. For Fig. 17d, equivalent (or

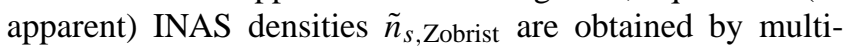
plying $j_{\text {imm }}$ as parameterized by Zobrist et al. (2007) with $\Delta t=10 \mathrm{~s}$, which corresponds to the approximate residence in e.g. a CFDC instrument. The contact angle is set to the fitted values provided by Marcolli et al. (2007) for ATD and by Lüönd et al. (2010) for kaolinite. As also noted in these studies, the temperature dependency of $\tilde{n}_{s, \text { Zobrist }}$ is much stronger than observed in experiments.

Better fits can be obtained by allowing a distribution of contact angles instead of single values (Marcolli et al., 2007; Lüönd et al., 2010). In this approach, every particle 
is assigned one value of the contact angle, such that the particles with the smallest contact angles are depleted when the temperature is lowered. To derive an apparent $\tilde{n}_{s, \theta \text {-pdf }}$, this depletion has to be taken into account. We proceed by calculating the IN fraction as given by Lüönd et al. (2010) and insert this value into Eq. (1) (for $f_{\mathrm{IN}}<0.9$ ):

$\tilde{n}_{s, \theta \text {-pdf }}=-\frac{1}{A_{\text {aer }}} \ln \left(\int p(\theta) \exp \left(-A_{\text {aer }} j_{\text {imm }}(\theta) \mathrm{d} t\right) \mathrm{d} \theta\right)$

$p(\theta)$ describes the probability distribution function of the contact angle $\theta$. The resulting INAS densities are displayed in Fig. 17e for ATD (Marcolli et al., 2007) and kaolinite (Lüönd et al., 2010). Compared to the CNT-curves with single contact angles for the same materials (Fig. 17d), these apparent INAS densities have a weaker dependency on temperature, and are similar to some of the $n_{\mathrm{s}}$-fits displayed in (Fig. 17a). However, the values of low $\tilde{n}_{s, \theta \text {-pdf }}$ at -15 to $-20^{\circ} \mathrm{C}$ are not supported by observations.

\subsection{Deposition nucleation parameterizations}

For deposition nucleation, the only aerosol-specific parameterizations which cover the full range of possible supersaturations and temperatures, are the empirical formulation by Phillips et al. (2008), or are based on classical nucleation theory. (Fitted INAS densitites for deposition nucleation are so far available only for narrow temperature ranges (Wheeler and Bertram, 2012; Kulkarni et al., 2012).) We will discuss these approaches in the light of the predicted temperatureand supersaturation dependency, expressed by the shape of onset curves in the $T-S_{\mathrm{i}}$ diagram.

\subsubsection{Comparison to observed shape of onset curves in $T-S_{\mathrm{i}}$ diagrams}

In Fig. 19, a subset of the data shown in Fig. 2 is connected by lines. Each line represents one experimental setup with constant particle size and/or the same material. Only those data are included for which the nucleation onset supersaturation for a specific temperature is given unambiguously in the original publication (in some cases obtained through averaging over several repetitions of the experiment). These lines can be interpreted as isolines of a constant INAS density $n_{\mathrm{S}}$ or a constant nucleation rate coefficient $j$. In the following, they are discussed as such isolines and compared to theoretical expectations.

Below water saturation, three different regimes can be distinguished. These are labelled A-C in Fig. 19b. At the lowest investigated temperatures $\left(\leq-50^{\circ} \mathrm{C}\right)$, an increase of the $j$-isolines or $n_{\mathrm{s}}$-isolines with decreasing temperature is frequently observed (regime A), i.e. higher supersaturations are required for the same number of particles to activate. This behaviour is contrary to the common assumption that lower temperatures always facilitate ice nucleation. In an intermediate temperature range, at relative humidities significantly below water saturation, the isolines are approximately horizontal (regime B). This corresponds to a temperatureindependent behaviour of deposition nucleation: only ice supersaturation determines the rate of nucleating particles. However, when approaching water saturation, the isolines are frequently bend towards higher supersaturations, i.e. deposition nucleation seems to be suppressed (regime C). Above water saturation, $j$ or $n_{\mathrm{s}}$ is a strong function of temperature (steep lines, regime D), and sets in at higher temperatures than below water saturation. The temperature-dependence of immersion freezing cannot be properly represented as isolines in the $T-S_{\mathrm{i}}$ diagram because the corresponding data are measured at water saturation. Schaller and Fukuta (1979) measured nearly vertical isolines for condensation freezing above water saturation. The CFDC measurements included in Fig. 19a have a large uncertainty in the maximum supersaturation seen by the aerosol particles, such that this regime is poorly resolved.

\subsubsection{Deposition nucleation parameterization based on atmospheric CFDC measurements}

The isolines of $\tilde{n}_{s, \text { Phillips, } X}\left(S_{\mathrm{i}}, T\right)$ (Eq. 5) are displayed in Fig. 20 for dust/metallic, black carbon and organic particles. While the reference IN concentration $n_{\mathrm{IN}, 1, *}$ in Eq. (5) mostly depends on $S_{\mathrm{i}}$, a strong temperature dependence is introduced by the factor $H_{X}\left(S_{\mathrm{i}}, T\right)$. This factor has been introduced to suppress ice nucleation at high temperatures and low supersaturations. The suppression is stronger for black carbon and organic aerosols than for dust/metallic particles. The resulting $\tilde{n}_{s}$-isolines for dust/metallic aerosols agree qualitatively well with the observations, while the $\tilde{n}_{s}$ isolines for black carbon and organic aerosols deviate moderately from the typical shape identified in Fig. 19.

\subsubsection{Deposition nucleation described by classical nucleation theory}

As for immersion freezing, different formulations of classical nucleation theory have been used in studies of deposition ice nucleation. These are summarized in Appendix A2. Fig. A1 shows isolines of the nucleation rate coefficient $j_{\text {dep }}$ for two different contact angles/form factors. The isolines calculated from classical nucleation theory are always quasi-horizontal close to water saturation (Fig. A1). At lower temperatures, Fletcher (1958)'s formulation of $A_{\text {dep }}$ does not reproduce the observed nucleation onset curves in regime $\mathrm{A}$, while Chen et al. (2008) and Barahona (2011) tend to agree qualitatively better with the experiments at low temperatures.

For the suppression of deposition nucleation close to water saturation (regime C), classical nucleation theory does not provide any explanation. Fukuta and Schaller (1982) and DeMott (1995) have attempted to cover this range with empirical fits. Other authors derived contact angles for individual data points along the nucleation onset curves, resulting in a strong variation of the contact angle close to water saturation 

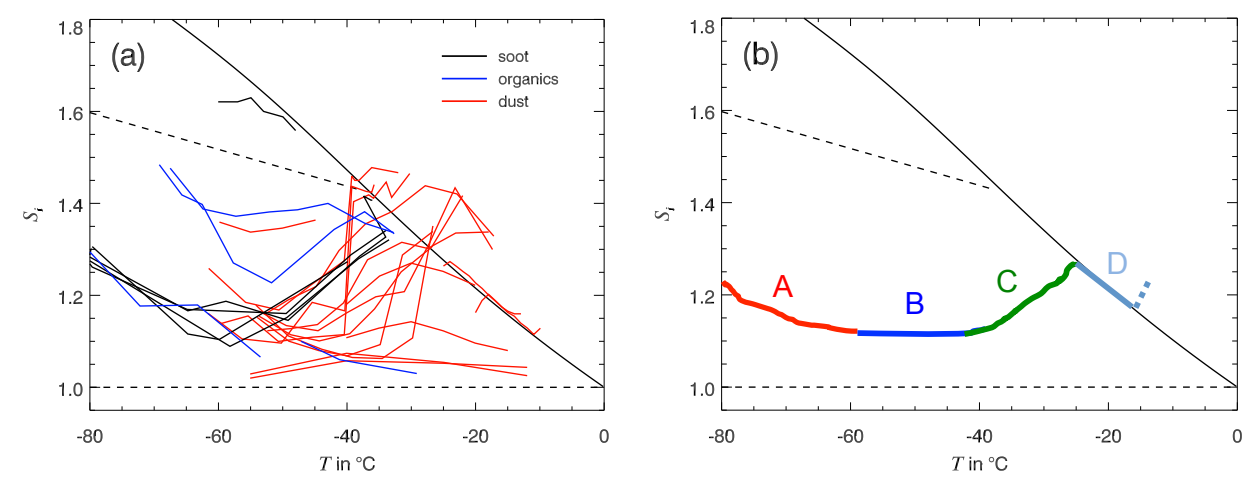

Fig. 19. Isolines of constant nucleation rate coefficients or INAS densities. (a) Selected data from Fig. 2. Each line connects data from one instrument, for one particle type and a constant activated fraction. (b) idealized curve with regimes A to D as discussed in the text.
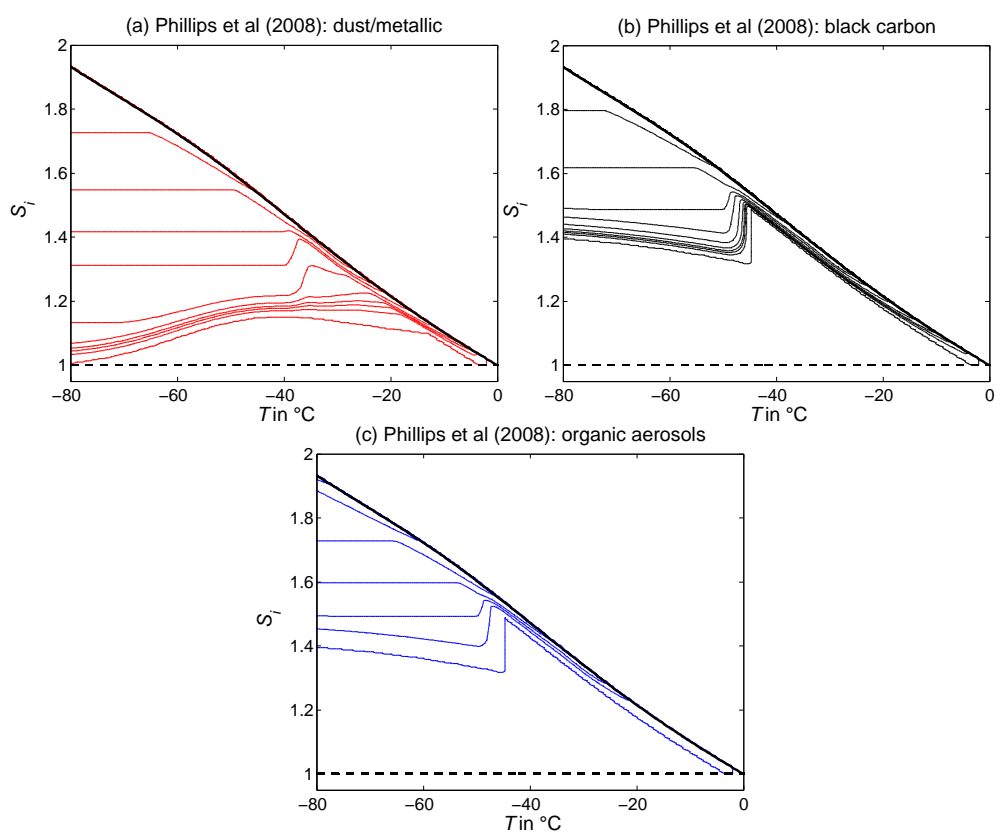

Fig. 20. Equivalent INAS densities for deposition and condensation nucleation as parameterized by Phillips et al. (2008): (a) dust/metallic aerosols, (b) black carbon, and (c) organic aerosols. The isolines correspond to (from bottom to top) $\tilde{n}_{S}\left(S_{\mathrm{i}}, T\right)=1,1 \times 10^{8}, 2 \times 10^{8}, 3 \times 10^{8}$,

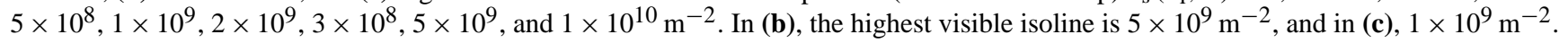

(Welti et al., 2009; Kulkarni and Dobbie, 2010). Physically, the observed behaviour of deposition nucleation might be related to water uptake in subsaturated conditions, which can occur both at the particle surface and within the bulk phase (swelling), depending on the particle composition (Schuttlefield et al., 2007). Mineral dust, which is usually considered to be insoluble, can contain various soluble components (Kelly et al., 2007; Herich et al., 2009).

\subsection{Time dependence in different parameterizations}

In any realization of an INAS density parameterization (Sect. 5.1.1), the resulting IN number at constant $T$ and $S_{\mathrm{i}}$ has zero time dependence, i.e. the IN are assumed to activate instantaneously, without measurable time delay. Conversely, all formulations of classical nucleation theory in Sects. 5.1.3 and 5.2.3 have in common that if they are applied to a population of aerosol particles with one value of the contact angle (and activation energy), they predict an increase in IN with observation time at constant $T$ and $S_{\mathrm{i}}$. For small activated fractions, the predicted IN number is proportional to time.

This time dependence is weaker, if not only one value of the contact angle is chosen, but a certain distribution of contact angles (as already discussed in Sect. 5.1.3). In different realizations, this idea was termed "singular hypothesis: contact angle distribution" (Marcolli et al., 2007), " $\alpha$-PDF model" (Lüönd et al., 2010), "multi-component stochastic model (Murray et al., 2011), "soccer ball modell" (Niedermeier et al., 2011b) or "nucleation probability dispersion 
function" (Barahona, 2011). A detailed discussion and comparison of these formulations goes beyond the scope of this paper, but they should be compared to experiments with the same aerosol particles at different cooling rates or residence times, such as those shown in Fig. 16.

\section{Conclusions}

In this compilation of results from six decades of laboratory experiments of heterogeneous ice nucleation, it has become obvious that many fundamental questions in this field are yet unsolved. Observed onset conditions for heterogeneous ice nucleation spread over large ranges of temperature and ice supersaturation, due to differences in methodology and nonstandardized reported variables. Normalization by activated fraction and particle surface area (i.e. estimates of the INAS density) leads to some convergence between different methods, but even for materials which are assumed to have a constant composition (e.g. ATD, kaolinite), the agreement is not satisfactory yet. Possible reasons could be impurities in the samples, different methods for the surface area determination, or instrumental biases.

Among the parameterizations intended for the description of ice nucleation in numerical models, those which are proportional to particle surface area have been discussed in more detail. Some fitted immersion freezing INAS densities, which do not include any a priori assumptions on temperaturedependence, have been shown to be unreliable outside the temperature range they were fitted to (Fig. 17a). This hinders their application in mesoscale or global models, in which the whole temperature range needs to be covered. Classical nucleation theory, in the different formulations with one contact angle employed for fits to measurements and implementation in models, fails to reproduce various aspects of observed heterogeneous ice nucleation: the temperature dependence for immersion nucleation, temperature and supersaturation dependence for deposition nucleation, and time dependence.

For future laboratory experiments of heterogeneous ice nucleation, we make the following recommendations:

- All experiments should as far as possible determine and document the size distribution of the investigated particles, the activated fraction, if known the nucleation mode, and the residence time or cooling rate.

- Experiments with polydisperse particles should report the total surface area to relate the ice nucleation activity to this parameter as shown in this manuscript. In particular for particles with complex composition like mineral dust, additional size-selected measurements are required to investigate whether the INAS density is constant over the whole size distribution.

- Results should be reported not only for one value of the activated fraction, but as spectra of the activated fraction versus temperature/supersaturation.
- Experiments with pure and homogeneous materials are needed to advance the understanding of the basic physical principles of heterogeneous ice nucleation (e.g. time dependence).

- Studies with natural aerosols under a broad range of conditions are needed in order to transfer laboratory results into parameterizations for models of the atmosphere.

- Further coordinated experiments with different instruments and identical samples (as in DeMott et al., 2011) are recommended to resolve instrument-dependent differences. In particular, such intercomparisons should strive for closure between single-mode methods (e.g. droplet freezing assays) and instruments covering multiple nucleation modes (CFDCs, cloud chambers).

- Spectroscopic, microscopic and chemical characterization methods should be used to determine the nature and location of the ice nucleation active sites on various materials.

- The concept of INAS densities should be extended to the analysis of experiments below water saturation (deposition nucleation/immersion freezing of concentrated solution droplets).

- It is desirable to work towards the derivation of ice nucleation parameterizations which cover the whole atmospherically relevant $T-S_{\mathrm{i}}$ space, while avoiding extrapolation to conditions which could not be probed. This will require a combination of different methods.

\section{Appendix A}

\section{Different formulations of classical nucleation theory}

\section{A1 Classical nucleation theory for immersion freezing}

The basic form of the nucleation rate coefficient $j_{\text {imm }}$ for immersion freezing is given by the following equation (Fletcher, 1962; Zobrist et al., 2007):

$j_{\mathrm{imm}}=A_{\mathrm{imm}} \exp \left(\frac{-\Delta F_{\mathrm{diff}}(T)-f_{\text {het }} \Delta G_{\mathrm{imm}}}{k T}\right)$

$\Delta G_{\mathrm{imm}}$ is the energy for homogeneous germ formation in the immersion mode, given by

$$
\Delta G_{\mathrm{imm}}=\frac{16 \pi v_{\mathrm{ice}}^{2}(T) \sigma_{\mathrm{i} / \mathrm{w}}^{3}(T)}{3\left(k T \ln \left(e_{\mathrm{s}, \mathrm{w}}(T) / e_{\mathrm{s}, \mathrm{i}}(T)\right)\right)^{2}}
$$

The temperature-dependent values of $v_{\mathrm{ice}}, \sigma_{\mathrm{i} / \mathrm{w}}, e_{\mathrm{s}, \mathrm{i}}$ and $e_{\mathrm{S}, \mathrm{w}}$ are given in Table A1. In the following, we employ the formulations by Zobrist et al. (2007). The energy of germ 
Table A1. List of symbols.

\begin{tabular}{|c|c|}
\hline symbol & description \\
\hline$a_{0}, a_{1}, a_{2}, a_{3}$ [various] & constants in Eq. (A5) \\
\hline$A_{\text {aer }}\left[\mathrm{m}^{2}\right]$ & aerosol surface area \\
\hline$A_{\mathrm{dep}}\left[\mathrm{m}^{-2} \mathrm{~s}^{-1}\right]$ & kinetic prefactor for deposition nucleation \\
\hline $\begin{array}{l}A_{\text {imm }}\left[\mathrm{m}^{-2} \mathrm{~s}^{-1}\right] \\
e[\mathrm{~Pa}]\end{array}$ & $\begin{array}{l}\text { kinetic prefactor for immersion freezing } \\
\text { water vapor pressure }\end{array}$ \\
\hline$E[\mathrm{~K}]$ & constant (892 K) (Zobrist et al., 2007) \\
\hline$e_{\mathrm{s}, \mathrm{i}}[\mathrm{Pa}]$ & saturation vapor pressure over ice (Murphy and Koop, 2005) \\
\hline$e_{\mathrm{S}, \mathrm{w}}[\mathrm{Pa}]$ & saturation vapor pressure over water (Murphy and Koop, 2005) \\
\hline$f_{\text {het }}[\#]$ & form factor \\
\hline$f_{\mathrm{IN}}[\#]$ & active fraction \\
\hline$\Delta F_{\text {diff }}[\mathrm{J}]$ & energy for diffusion across the liquid-ice boundary \\
\hline$\Delta g_{\mathrm{d}}[\mathrm{J}]$ & desorption energy \\
\hline$\Delta G_{\mathrm{dep}}[\mathrm{J}]$ & energy for homogeneous germ formation in the deposition mode \\
\hline$\Delta G_{\mathrm{imm}}[\mathrm{J}]$ & energy for homogeneous germ formation in the immersion mode \\
\hline$h[\mathrm{~J} \mathrm{~s}]$ & Planck constant $\left(6.63 \times 10^{-34} \mathrm{~J} \mathrm{~s}\right)$ \\
\hline$H_{X}[\#]$ & prefactor ranging from $0-1$ (Phillips et al., 2008) \\
\hline$j_{\text {het }}\left[\mathrm{m}^{-2} \mathrm{~s}^{-1}\right]$ & heterogeneous nucleation rate coefficient \\
\hline$j_{\text {dep }}\left[\mathrm{m}^{-2} \mathrm{~s}^{-1}\right]$ & deposition nucleation rate coefficient \\
\hline$j_{\mathrm{imm}}\left[\mathrm{m}^{-2} \mathrm{~s}^{-1}\right]$ & immersion freezing rate coefficient \\
\hline$k\left[\mathrm{~J} \mathrm{~K}^{-1}\right]$ & Boltzmann constant $\left(1.38 \times 10^{-23} \mathrm{~J} \mathrm{~K}^{-1}\right)$ \\
\hline$m_{\mathrm{W}}[\mathrm{kg}]$ & mass of a water molecule $\left(2.99 \times 10^{-26} \mathrm{~kg}\right)$ \\
\hline$n_{1, \mathrm{w}}\left[\mathrm{m}^{-2}\right]$ & number of single molecules in contact with unit area of the substrate (in liquid water) $\left(10^{19} \mathrm{~m}^{-2}\right.$, Chen et al., 2008) \\
\hline$n_{\mathrm{IN}, 1, *}\left[\mathrm{~m}^{-3}\right]$ & reference IN spectrum (Phillips et al., 2008) \\
\hline$n_{s}\left[\mathrm{~m}^{-2}\right]$ & INAS density \\
\hline$p(\theta)\left[1 /^{\circ}\right]$ & contact angle distribution \\
\hline$S_{\mathrm{i}}[\#]$ & saturation ratio with respect to ice \\
\hline$\Delta t[\mathrm{~s}]$ & time interval \\
\hline$T[\mathrm{~K}]$ & temperature \\
\hline$T_{0}[\mathrm{~K}]$ & melting point of water $(273.15 \mathrm{~K})$ \\
\hline$T_{0 Z}[\mathrm{~K}]$ & constant $(118 \mathrm{~K})$ (Zobrist et al., 2007) \\
\hline$T_{c}\left[{ }^{\circ} \mathrm{C}\right]$ & temperature in ${ }^{\circ} \mathrm{C}$ \\
\hline$v_{\text {ice }}\left[\mathrm{m}^{3}\right]$ & volume of a water molecule in ice $\left(=m_{\mathrm{w}} / \rho_{\mathrm{i}}\right)$ \\
\hline$X$ & index: $X=$ dust/metallic, black carbon and organic aerosols (Phillips et al., 2008) \\
\hline$\alpha_{c}[\#]$ & mass accomodation coefficient (Barahona, 2011) \\
\hline$\alpha_{X}[\#]$ & fractional contribution of aerosol $X$ to the background IN spectrum $n_{\mathrm{IN}, 1, *}$ (Phillips et al., 2008) \\
\hline$\theta\left[{ }^{\circ}\right]$ & contact angle \\
\hline$v_{\mathrm{s}}\left[1 \mathrm{~s}^{-1}\right]$ & $\begin{array}{l}\text { frequency of vibration of water vapor molecule adsorbed on solid substrate, } 10^{13} \mathrm{~s}^{-1} \text { (Pruppacher and Klett, 1997, } \\
\text { p. 299) }\end{array}$ \\
\hline$\xi[\#]$ & temperature-dependent function ranging from $0-1$ (Phillips et al., 2008) \\
\hline$\rho_{\mathrm{i}}\left[\mathrm{kg} \mathrm{m}^{-3}\right]$ & $\begin{array}{l}\text { density of ice }\left(\rho_{\mathrm{i}}=916.7 /\left(1-0.05294 \times\left(T-T_{0}\right) / T_{0}-0.05637 \times\left(\left(T-T_{0}\right) / T_{0}\right)^{2}-0.002913 \times\left(\left(T-T_{0}\right) / T_{0}\right)^{3}\right)(\text { Zobrist }\right. \\
\text { et al., 2007) or } \rho_{\mathrm{i}}=916.7-0.175 T_{c}-5 \cdot 10^{-4} T_{c}^{2} \text { (Pruppacher and Klett, 1997, Eq. (3-2))) }\end{array}$ \\
\hline$\sigma_{\mathrm{i} / \mathrm{v}}\left[\mathrm{J} \mathrm{m}^{-2}\right]$ & $\begin{array}{l}\text { surface tension between ice and vapor }\left(=\sigma_{\mathrm{i} / \mathrm{w}}+\sigma_{\mathrm{w} / \mathrm{v}}=\left(76.1-0.155 * T_{c}+28.5+0.25 * T_{c}\right) \times 10^{-3} \text { (Pruppacher and }\right. \\
\text { Klett, 1997, Eqs. (5-46), (5-47a) and }(5-12))\end{array}$ \\
\hline$\sigma_{\mathrm{i} / \mathrm{w}}\left[\mathrm{J} \mathrm{m}^{-2}\right]$ & surface tension between ice and water $\left(\sigma_{\mathrm{i} / \mathrm{w}}=3.298 \times 10^{-2}+1.2048 \times 10^{-2}\left(T-T_{0}\right) / T_{0}-0.46705\left(T-T_{0}\right)^{2} / T_{0}^{2}\right.$ \\
\hline$\Omega_{X, 1, *}\left[\mathrm{~m}^{2} \mathrm{~kg}^{-1}\right]$ & $\begin{array}{l}\text { (Zobrist et al., 2007) or } \sigma_{\mathrm{i} / \mathrm{w}}=\left(28+0.25 T_{c}\right) \times 10^{-3} \text { (Pruppacher and Klett, 1997, Eqs. (5-47a))) } \\
\text { aerosol surface area mixing ratio of species } X \text { in the reference scenario (Phillips et al., 2008) }\end{array}$ \\
\hline
\end{tabular}

formation is lowered by the foreign substrate to the value $f_{\text {het }} \Delta G_{\text {imm }}(T)$, where the form factor $f_{\text {het }}$ can assume values between 0 and 1. $f_{\text {het }}$ is related to the contact angle $\theta$ via $f_{\text {het }}=(2+\cos \theta)(1-\cos \theta)^{2} / 4$ if the curvature effect is neglected (Pruppacher and Klett, 1997).

For the activation energy/energy for diffusion across the liquid-ice boundary $\Delta F_{\text {diff }}$, and the prefactor $A_{\text {imm }}$, different assumptions have been used. Zobrist et al. (2007) provide a parameterization for $\Delta F_{\text {diff }}$ which is based on measurements of the diffusivity. For the prefactor a simplified form is used, in which the Zeldovich factor multiplied by the number of water molecules contacting the ice germ is approximated by 1 (Pruppacher and Klett, 1997, their Eqs. 9-37).

$$
\begin{aligned}
\Delta F_{\text {diff, Zobrist }} & =\frac{k T^{2} E}{\left(T-T_{0 Z}\right)^{2}} \\
A_{\text {imm, Zobrist }} & =n_{1, \mathrm{w}} \frac{k T}{h}
\end{aligned}
$$


Table A2. List of abbreviations.

\begin{tabular}{ll}
\hline Instrument types \\
\hline AFT & aerosol flow tube \\
CC & cold chamber \\
CECC & controlled expansion cloud chamber \\
CFDC & continuous flow diffusion chamber \\
CFDC-C & CFDC with cylindrical plates \\
CFDC-P & CFDC with parallel plates \\
CFMC & continuous flow mixing chamber \\
CS & cold stage \\
CS-FDC & cold stage in flow diffusion cell \\
CS-SDC & cold stage in static diffusion cell \\
DFA & droplet freezing assay \\
DMCC & dynamic mixing cloud chamber \\
DSC & differential scanning calorimeter \\
EDBC & electrodynamic balance cell \\
EDF & emulsified droplet freezing \\
ESEM & environmental scanning electron microscope \\
FA & freezing assay \\
FDNC & falling droplet nucleation chamber \\
ISDC & isothermal static diffusion chamber \\
LFT & laminar flow tube \\
VWT & vertical wind tunnel \\
\hline Instrument names and institutions \\
\hline AIDA & Aerosol Interaction and Dynamics in the Atmosphere \\
CINaM & Centre Interdisciplinaire de Nanoscience de Marseille \\
CIRES & Cooperative Institute for Research in Environmental \\
& Sciences, University of Colorado \\
CLINCH & Collision Ice Nucleation Chamber \\
CSU & Colorado State University \\
DRI & Desert Research Institute \\
ETHZ & ETH (Eidgenössische Technische Hochschule) Zurich \\
FINCH & Fast Ice Nucleus Chamber \\
FRIDGE & FRankfurt Ice Nuclei Deposition FreezinG Experiment \\
IMCA & Immersion mode cooling chamber \\
INRA & Institut National de la Recherche Agronomique \\
LACIS & Leipzig Aerosol Cloud Interaction Simulator \\
MINC & Manchester Ice Nucleus Counter \\
PINC & Portable Ice Nucleation Chamber \\
PNNL & Pacific Northwest National Laboratory \\
PNNL-CIC & PNNL Compact Ice Chamber \\
U & University (of) \\
UBC & University of British Columbia, Vancouver \\
UBP & Université Blaise Pascal, Clermont-Ferrand \\
ZINC & Zurich Ice Nucleation Chamber \\
\hline & tion \\
\hline
\end{tabular}

other abbreviations

\begin{tabular}{ll}
\hline AD & Asian dust \\
ATD & Arizona test dust \\
CAST & Combustion Aerosol STandard \\
CCN & Cloud condensation nuclei \\
CID & Canary Island dust \\
CNT & Classical nucleation theory \\
HULIS & humic-like substances \\
IN & ice nuclei \\
INA & ice nucleation active \\
INAS & ice nucleation active (surface) site \\
n.a. & not available \\
OC & organic carbon \\
pdf & probability distribution function \\
SD & Saharan dust \\
SOA & secondary organic aerosol \\
\hline
\end{tabular}

The constants $n_{1, \mathrm{w}}, k, h$ are explained in Table A1. The fitted parameters for $\Delta F_{\text {diff, Zobrist }}$ are $E=892 \mathrm{~K}$ and $T_{0 Z}=$ $118 \mathrm{~K}$.

Fornea et al. (2009) use the activation energy for the selfdiffusion of water (Pruppacher and Klett, 1997, their Eqs. 322), and the same prefactor as Zobrist et al. (2007):

$$
\begin{aligned}
\Delta F_{\text {diff, Fornea }} & =a_{0} \exp \left(a_{1} T_{c}+a_{2} T_{c}^{2}+a_{3} T_{c}^{3}\right) \\
A_{\text {imm, Fornea }} & =A_{\text {imm, Zobrist }}=n_{1, \mathrm{w}} \frac{k T}{h}
\end{aligned}
$$

with $a_{0}=4184 /\left(6.022 \times 10^{23}\right) \times 5.55 \mathrm{~J}, a_{1}=-8.423 \times 10^{-3}$, $a_{2}=6.384 \times 10^{-4}$ and $a_{3}=7.891 \times 10^{-6}$.

Chen et al. (2008) employed $\Delta F_{\text {diff }}$ as an additional temperature-independent fit parameter, with values ranging from 9.9 to $16 \times 10^{-20} \mathrm{~J}$. In addition, the surface area of the ice germ and the Zeldovich factor, which describes the depletion of the embryo population due to germ production, are taken into account in the prefactor:

$$
\begin{aligned}
A_{\text {imm, Chen }}= & n_{1, \mathrm{w}} \frac{k T}{h} \\
& \times \frac{\left(k T \ln \left(e_{\mathrm{s}, \mathrm{w}} / e_{\mathrm{s}, \mathrm{i}}\right)\right)^{2}}{4 v_{\mathrm{ice}} \sigma_{\mathrm{i} / \mathrm{w}}^{2}} \sqrt{\frac{4 \sigma_{\mathrm{i} / \mathrm{w}}}{k T}} \sqrt{f_{\text {het }}}
\end{aligned}
$$

Murray et al. (2011) do not make explicit assumptions about $\Delta F_{\text {diff }}$ and $A_{\text {imm }}$, but implicitly assume that $A_{\text {imm }} \exp \left(-\Delta F_{\text {diff }} /(k T)\right)$ varies only weakly with temperature. Similarly, Niedermeier et al. (2010) used $A_{\text {imm }} \exp \left(-\Delta F_{\text {diff }} /(k T)\right)$ as a (temperature-independent) fit parameter. Khvorostyanov and Curry (2004) provide a unified treatment of deliquescence and condensation freezing, in which the energy for homogeneous germ formation has a different form than Eq. A2 and requires knowledge about additional parameters (see also Curry and Khvorostyanov, 2012). Their prefactor $A_{\text {imm }}$ is identical to Zobrist et al. (2007), but the activation energy has a different temperature-dependent form (Khvorostyanov and Sassen, 1998):

$$
\begin{aligned}
\Delta F_{\text {diff, Khvorostyanov }}= & 0.694 \times 10^{-19} \mathrm{~J} \times \\
& \left(1+0.0027 \times\left(T_{c}+30\right)\right) \\
A_{\text {imm, Khvorostyanov }}= & A_{\text {imm }, \text { Zobrist }}=n_{1, \mathrm{w}} \frac{k T}{h}
\end{aligned}
$$

The implications of these different formulations for $\Delta F_{\text {diff }}$ (displayed in Fig. A2) and $A_{\text {imm }}$ will be discussed in the following.

In Fig. A3, equivalent INAS densities $\tilde{n}_{s}$ based on Eq. (A1) are shown. The equivalent INAS densities are obtained by multiplying $j_{\text {imm }}$ with $\Delta t=10 \mathrm{~s}$, which corresponds to the approximate residence in e.g. a CFDC instrument. The form factor $f_{\text {het }}$ is varied from 0.01 to 0.9 . The parameterization of $\Delta F_{\text {diff }}$ has a strong impact on the temperature dependence of $j_{\text {imm. }}$. With Zobrist et al. (2007)'s and Fornea et al. (2009)'s parameterizations, $j_{\mathrm{imm}} \cdot \Delta t$ increases much more sharply with decreasing temperatures than measurements (Fig. 13) 

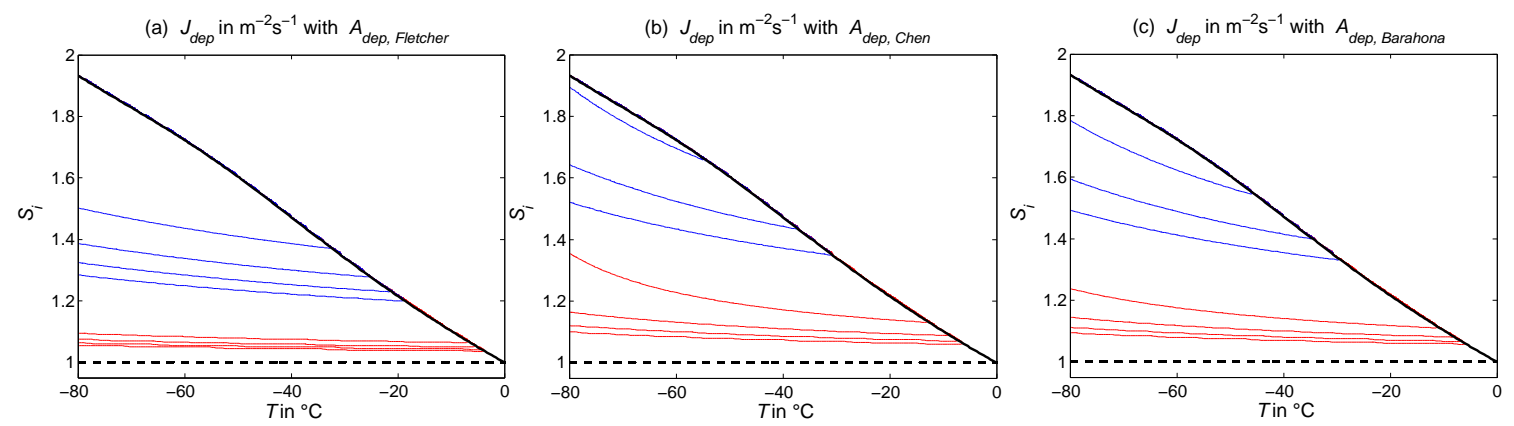

Fig. A1. Deposition nucleation rates calculated from classical nucleation theory, with different formulations of the kinetic factor $A_{\text {dep }}$ (a) Fletcher (1958), (b) Chen et al. (2008), and (c) Barahona (2011). The red lines are valid for $f_{\text {het }}=0.0005$, and the blue lines for $f_{\text {het }}=0.01$. From bottom to top, the isolines correspond to $j_{\mathrm{dep}}=1,1 \times 10^{6}, 1 \times 10^{12}$, and (beyond the plotting range for the blue lines in $\mathbf{b}$ and $\mathbf{c}$ ) $1 \times 10^{18} \mathrm{~m}^{-2} \mathrm{~s}^{-1}$. In (b) and (c), a desorption energy $\Delta g_{\mathrm{d}}$ of $6.5 \times 10^{-20} \mathrm{~J}$ was used.

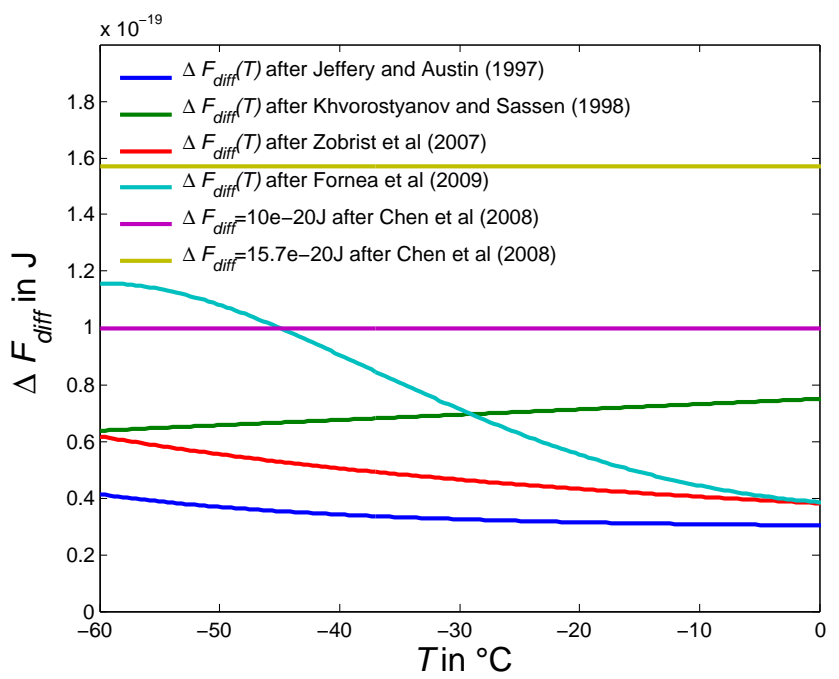

Fig. A2. Energy for diffusion across the liquid-ice boundary $\Delta F_{\text {diff }}$ as used in different immersion freezing formulations of classical nucleation theory.

or fitted parameterizations of $n_{\mathrm{S}}$ (Fig. 17) indicate. With fitted temperature-independent values of $\Delta F_{\text {diff }}$ (Chen et al., 2008), the temperature characteristic of $j_{\mathrm{imm}} \cdot \Delta t$ is more similar to observations (see e.g. the fitted functions in Hoose et al. (2010b)). However, this approach has two disadvantages: First, at low temperatures, $j_{\text {imm }}$ decreases after reaching a certain maximum, which is not supported by observations. Second, by using $\Delta F_{\text {diff }}$ as a fit parameter, its physical meaning is ignored.

\section{A2 Classical nucleation theory for deposition nucleation}

Fletcher (1958) gives the nucleation rate per particle by deposition nucleation as

$j_{\text {dep }}=A_{\text {dep }} \exp \left(-\frac{f_{\text {het }} \Delta G_{\text {dep }}}{k T}\right)$, where $A_{\mathrm{dep}}$ is a kinetic prefactor and the exponential term describes the thermodynamics, including the effect of the ice nucleus on the formation of the ice germ. The energy of homogeneous germ formation from the gas phase, $\Delta G_{\text {dep }}$, included in the exponential term (the thermodynamic factor), can be spelled out in the following way:

$\Delta G_{\mathrm{dep}}=\frac{16 \pi v_{\mathrm{ice}}^{2}(T) \sigma_{\mathrm{i} / \mathrm{v}}^{3}(T)}{3\left(k T \ln S_{\mathrm{i}}\right)^{2}}$

The surface tension between ice and vapor, $\sigma_{\mathrm{i} / \mathrm{v}}$, and the volume of a water molecule in ice, $v_{\text {ice }}$, are temperature dependent (see Table A1). However, the overall variation with temperature of the thermodynamic factor is much slower than the variation with supersaturation. Between 200 and $270 \mathrm{~K}$, the term in Eq. (A11) varies only by about a factor 3 if the supersaturation is held constant. However, if temperature is held constant and supersaturation is varied between 1.2 and 1.8 , it changes by a factor of more than $10^{10}$.

According to Fletcher (1958), the kinetic prefactor is approximately constant with the following value:

$A_{\text {dep, Fletcher }}=10^{29} \mathrm{~m}^{-2} \mathrm{~s}^{-1}$

This constant value has been adopted in recent analyses of ice nucleation experiments (Eastwood et al., 2008; Kulkarni and Dobbie, 2010). With Fletcher (1958)'s formulation, the isolines of $j_{\text {dep }}$ are near-horizontal in the $T-S_{\mathrm{i}}$ diagram (Fig. A1a).

In two other recent implementations of classical nucleation theory, the kinetic factor $A_{\text {dep }}$ is a function of both supersaturation and temperature. Chen et al. (2008) give the following expression :

$A_{\text {dep, Chen }}=\frac{S_{\mathrm{i}}^{2} e_{\mathrm{s}, \mathrm{i}}^{2} v_{\text {ice }}}{m_{\mathrm{w}} k T v_{\mathrm{s}}} \sqrt{\frac{\sigma_{\mathrm{i} / \mathrm{v}}}{k T}} \sqrt{f_{\text {het }}} \exp \left(\frac{\Delta g_{\mathrm{d}}}{k T}\right)$

Chen et al. (2008) use the desorption energy $\Delta g_{\mathrm{d}}$ as a fit parameter, similar to $\Delta F_{\text {diff }}$ for immersion freezing. The values 

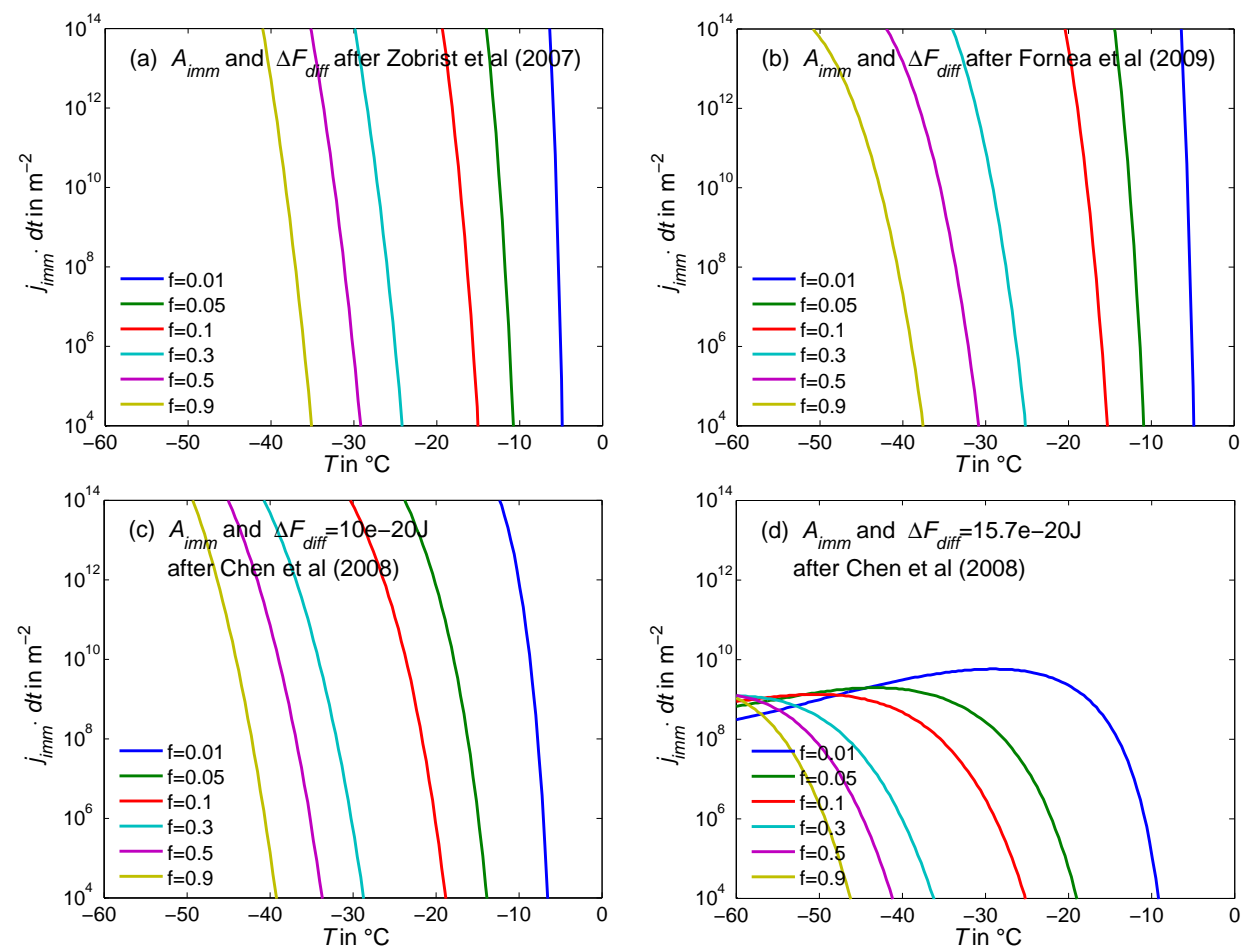

Fig. A3. Equivalent INAS densities calculated obtained from various formulations of classical nucleation theory by multiplying immersion freezing rate coefficients with an exemplary time step of $10 \mathrm{~s}$, shown for different form factors $f$.

derived by Chen et al. (2008) for Asian dust, Saharan dust and ATD range from $3.3 \times 10^{-20} \mathrm{~J}$ to $4.9 \times 10^{-20} \mathrm{~J}$.

Conversely, the expression used by Barahona (2011) differs with respect to the exponent of the form factor $f_{\text {het }}$ and includes a mass accomodation coefficient $\alpha_{c}$ :

$A_{\mathrm{dep}, \text { Barahona }}=\frac{S_{\mathrm{i}}^{2} e_{\mathrm{s}, \mathrm{i}}^{2} v_{\mathrm{ice}}}{m_{\mathrm{w}} k T v_{\mathrm{s}}} \sqrt{\frac{\sigma_{\mathrm{i} / \mathrm{v}}}{k T}} \frac{\alpha_{c}}{\sqrt{f_{\mathrm{het}}}} \exp \left(\frac{\Delta g_{\mathrm{d}}}{k T}\right)$

Barahona (2011) prescribes a desorption energy of $\Delta g_{\mathrm{d}}=$ $6.5 \times 10^{-20} \mathrm{~J}$ for mineral dust and $\Delta g_{\mathrm{d}}=4.4 \times 10^{-20} \mathrm{~J}$ for soot (Seisel et al., 2005).

In Eqs. (A13) and (A14), the saturation vapour pressure over ice $\left(e_{\mathrm{s}, \mathrm{i}}\right)$ is strongly temperature dependent and dominates the functional behaviour of $A_{\mathrm{dep}}$, Chen and $A_{\text {dep, Barahona. }}$ Physically, this can be explained with a slowdown of the deposition of water molecules from the vapour phase at lower temperatures. The resulting $j_{\text {dep }}$ (Fig. A1b, c) exhibits a (small) decrease with decreasing temperatures.

With different assumptions about the prefactor, the contact angles derived from experimental data are also substantially different and not intercomparable (Chen et al., 2008; Hoose et al., 2010b; Eastwood et al., 2008; Fornea et al., 2009; Marcolli et al., 2007; Welti et al., 2009; Kulkarni and Dobbie, 2010).
Acknowledgements. We acknowledge all authors of the numerous original studies which are analysed in this work. Jen-Ping Chen, Paul DeMott, Hinrich Grothe, Kristina Höhler, Zamin Kanji, Alexei Kiselev, Daniel Knopf, Thomas Leisner, Ulrike Lohmann, Cindy Morris, Benjamin Murray, Dennis Niedermeier, Monika Niemand, Valeria Pinti, Bernhard Pummer, Isabelle Steinke, Robert Wagner, Bingbing Wang and Aldona Wiacek are thanked for inspirations, thoughtful comments, helpful discussions and additional information on published data. The comments of two anonymous referees have lead to significant improvements of this manuscript. The free software g3data was used for the extraction of data from graphs, and its developers are gratefully acknowledged. We acknowledge support by the Deutsche Forschungsgemeinschaft and the Open Access Publishing Fund of the Karlsruhe Institute of Technology. Part of this research was funded by the Helmholtz Association through the President's Initiative and Networking Fund and by the Deutsche Forschungsgemeinschaft through project FOR 1525 .

The service charges for this open access publication have been covered by a Research Centre of the Helmholtz Association.

Edited by: T. Koop 


\section{References}

Abbatt, J. P. D., Benz, S., Cziczo, D. J., Kanji, Z., Lohmann, U., and Möhler, O.: Solid ammonium sulfate aerosols as ice nuclei: a pathway for cirrus cloud formation, Science, 313, 1770-1773, doi:10.1126/science.1129726, 2006.

Ahern, H. E., Walsh, K. A., Hill, T. C. J., and Moffett, B. F.: Fluorescent pseudomonads isolated from Hebridean cloud and rain water produce biosurfactants but do not cause ice nucleation, Biogeosciences, 4, 115-124, doi:10.5194/bg-4-115-2007, 2007.

Alpert, P. A., Aller, J. Y., and Knopf, D. A.: Ice nucleation from aqueous $\mathrm{NaCl}$ droplets with and without marine diatoms, Atmos. Chem. Phys., 11, 5539-5555, doi:10.5194/acp-11-55392011, 2011a.

Alpert, P. A., Aller, J. Y., and Knopf, D. A.:Initiation of the ice phase by marine biogenic surfaces in supersaturated gas and supercooled aqueous phases, Phys. Chem. Chem. Phys., 13, 1988219894, doi:10.1039/c1cp21844a, 2011 b.

Archuleta, C. M., DeMott, P. J., and Kreidenweis, S. M.: Ice nucleation by surrogates for atmospheric mineral dust and mineral dust/sulfate particles at cirrus temperatures, Atmos. Chem. Phys., 5, 2617-2634, doi:10.5194/acp-5-2617-2005, 2005.

Attard, E., Yang, H., Delort, A.-M., Amato, P., Pöschl, U., Glaux, C., Koop, T. and Morris, C. E.: Effects of atmospheric conditions on ice nucleation activity of Pseudomonas, Atmos. Chem. Phys. Discuss., 12, 9491-9516, doi:10.5194/acpd-129491-2012, 2012.

Bailey, M. and Hallett, J.: Nucleation effects on the habit of vapour grown ice crystals from -18 to $-42{ }^{\circ} \mathrm{C}$, Q. J. Roy. Meteor. Soc., 128, 1461-1483, 2002.

Barahona, D.: On the ice nucleation spectrum, Atmos. Chem. Phys., 12, 3733-3752, doi:10.5194/acp-12-3733-2012, 2012.

Baustian, K. J., Wise, M. E., and Tolbert, M. A.: Depositional ice nucleation on solid ammonium sulfate and glutaric acid particles, Atmos. Chem. Phys., 10, 2307-2317, doi:10.5194/acp-10-23072010, 2010.

Beaver, M. R., Elrod, M. J., Garland, R. M., and Tolbert, M. A.: Ice nucleation in sulfuric acid/organic aerosols: implications for cirrus cloud formation, Atmos. Chem. Phys., 6, 3231-3242, doi:10.5194/acp-6-3231-2006, 2006.

Bigg, E. K.: The formation of atmospheric ice crystals by the freezing of droplets, Q. J. Roy. Meteor. Soc., 79, 510-519, doi:10.1002/qj.49707934207, 1953.

Bingemer, H., Klein, H., Ebert, M., Haunold, W., Bundke, U., Herrmann, T., Kandler, K., Müller-Ebert, D., Weinbruch, S., Judt, A., Wéber, A., Nillius, B., Ardon-Dryer, K., Levin, Z., and Curtius, J.: Atmospheric ice nuclei in the Eyjafjallajökull volcanic ash plume, Atmos. Chem. Phys., 12, 857-867, doi:10.5194/acp12-857-2012, 2012.

Broadley, S. L., Murray, B. J., Herbert, R. J., Atkinson, J. D., Dobbie, S., Malkin, T. L., Condliffe, E., and Neve, L.: Immersion mode heterogeneous ice nucleation by an illite rich powder representative of atmospheric mineral dust, Atmos. Chem. Phys., 12, 287-307, doi:10.5194/acp-12-287-2012, 2012.

Brunauer, S., Emmett, P. H., and Teller, E.: Adsorption of gases in multimolecular layers, J. Am. Chem. Soc., 60, 309-319, 1938.

Bundke, U., Nillius, B., Jaenicke, R., Wetter, T., Klein, H., and Bingemer, H.: The fast Ice Nucleus chamber FINCH, Atmos. Res., 90, 180-186, 2008.
Bunker, K. W., China, S., Mazzoleni, C., Kostinski, A., and Cantrell, W.: Measurements of ice nucleation by mineral dusts in the contact mode, Atmos. Chem. Phys. Discuss., 12, 2029120309, doi:10.5194/acpd-12-20291-2012, 2012.

Chen, J.-P., Hazra, A., and Levin, Z.: Parameterizing ice nucleation rates using contact angle and activation energy derived from laboratory data, Atmos. Chem. Phys., 8, 7431-7449, doi:10.5194/acp-8-7431-2008, 2008.

Chen, Y., Demott, P. J., Kreidenweis, S. M., Rogers, D. C., and Sherman, D. E.: Ice formation by sulfate and sulfuric acid aerosol particles under upper-tropospheric conditions, J. Atmos. Sci., 57, 3752-3766, 2000.

Chernoff, D. I. and Bertram, A. K.: Effects of sulfate coatings on the ice nucleation properties of a biological ice nucleus and several types of minerals, J. Geophys. Res., 115, D20205, doi:10.1029/2010JD014254, 2010.

Chou, C., Stetzer, O., Tritscher, T., Chirico, R., Heringa, M. F., Kanji, Z. A., Weingartner, E., Prévôt, A. S. H., Baltensperger, U., and Lohmann, U.: Effect of photochemical aging on the ice nucleation properties of diesel and wood burning particles, Atmos. Chem. Phys. Discuss., 12, 14697-14726, doi:10.5194/acpd-1214697-2012, 2012.

Conen, F., Morris, C. E., Leifeld, J., Yakutin, M. V., and Alewell, C.: Biological residues define the ice nucleation properties of soil dust, Atmos. Chem. Phys., 11, 9643-9648, doi:10.5194/acp-119643-2011, 2011.

Connolly, P. J., Möhler, O., Field, P. R., Saathoff, H., Burgess, R., Choularton, T., and Gallagher, M.: Studies of heterogeneous freezing by three different desert dust samples, Atmos. Chem. Phys., 9, 2805-2824, doi:10.5194/acp-9-2805-2009, 2009.

Constantinidou, H. A., Hirano, S. S., Baker, L. S., and Upper, C. D.: Atmospheric dispersal of ice nucleation-active bacteria: the role of rain, Phytopathology, 80, 934-937, 1990.

Crawford, I., Möhler, O., Schnaiter, M., Saathoff, H., Liu, D., McMeeking, G., Linke, C., Flynn, M., Bower, K. N., Connolly, P. J., Gallagher, M. W., and Coe, H.: Studies of propane flame soot acting as heterogeneous ice nuclei in conjunction with single particle soot photometer measurements, Atmos. Chem. Phys., 11, 9549-9561, doi:10.5194/acp-11-9549-2011, 2011.

Curry, J. A. and Khvorostyanov, V. I.: Assessment of some parameterizations of heterogeneous ice nucleation in cloud and climate models, Atmos. Chem. Phys., 12, 1151-1172, doi:10.5194/acp12-1151-2012, 2012.

Cziczo, D. J., Froyd, K. D., Gallavardin, S. J., Moehler, O., Benz, S., Saathoff, H., and Murphy, D. M.: Deactivation of ice nuclei due to atmospherically relevant surface coatings, Environ. Res. Lett., 4, 044013, doi:10.1088/1748-9326/4/4/044013, 2009a.

Cziczo, D. J., Stetzer, O., Worringen, A., Ebert, M., Weinbruch, S., Kamphus, M., Gallavardin, S. J., Curtius, J., Borrmann, S., Froyd, K. D., Mertes, S., Möhler, O., and Lohmann, U.: Inadvertent climate modification due to anthropogenic lead, Nat. Geosci., 2, 333-336, doi:10.1038/ngeo499, 2009b.

Demirdjian, B., Ferry, D., Suzanne, J., Popovicheva, O. B., Persiantseva, N. M., Kamaev, A. V., Shonija, N. K., and Zubareva, N. A.: Freezing of water adsorbed on hydrophobic and activated soot particles, Chem. Phys. Lett., 480, 247-252, 2009.

DeMott, P. J.: An exploratory study of ice nucleation by soot aerosols, J. Appl. Meteorol., 29, 1072-1079, 1990. 
DeMott, P. J.: Quantitative descriptions of ice formation mechanisms of silver iodide-type aerosols, Atmos. Res., 38, 63-99, 1995.

DeMott, P. J.: Laboratory studies of cirrus cloud processes, in: Cirrus, edited by: Lynch, D. K., Sassen, K., Starr, D. O., and Stephens, G., Oxford University Press, New York, NY, USA, 2002.

DeMott, P. J., Chen, Y., Kreidenweis, S. M., Rogers, D. C., and Sherman, D. E.: Ice formation by black carbon particles, Geophys. Res. Lett., 26, 2429-2432, 1999.

DeMott, P. J., Petters, M. D., Prenni, A. J., Carrico, C. M., Kreidenweis, S. M., Collett Jr., J. L., and Moosmüller, H.: Ice nucleation behavior of biomass combustion particles at cirrus temperatures, J. Geophys. Res., 114, D16205, doi:10.1029/2009JD012036, 2009.

DeMott, P. J., Prenni, A. J., Liu, X., Kreidenweis, S. M., Petters, M. D., Twohy, C. H., Richardson, M. S., Eidhammer, T., and Rogers, D. C.: Predicting global atmospheric ice nuclei distributions and their impacts on climate, P. Natl. Acad. Sci. USA, 107, 11217-11222, 2010.

DeMott, P. J., Möhler, O., Stetzer, O., Vali, G., Levin, Z., Petters, M. D., Murakami, M., Leisner, T., Bundke, U., Klein, H., Kanji, Z. A., Cotton, R., Jones, H., Benz, S., Brinkmann, M., Rzesanke, D., Saathoff, H., Nicolet, M., Saito, A., Nillius, B., Bingemer, H., Abbatt, J., Ardon, K., Ganor, E., Georgakopoulos, D. G., and Saunders, C.: Resurgence in ice nuclei measurement research, B. Am. Meteorol. Soc., 92, 1623-1635, doi:10.1175/2011BAMS3119.1, 2011.

Després, V. R., Huffman, J. A., Burrows, S. M., Hoose, C., Safatov, A. S., Buryak, G., Fröhlich-Nowoisky, J., Elbert, W., Andreae, M. O., Pöschl, U., and Jaenicke, R.: Primary biological aerosol particles in the atmosphere: a review, Tellus B, 64, 15598, doi:10.3402/tellusb.v64i0.15598, 2012.

Diehl, K. and Mitra, S. K.: A Laboratory study of the effects of a Kerosene-burner exhaust on ice nucleation and the evaporation rate of ice crystals, Atmos. Environ., 32, 3145-3151, 1998.

Diehl, K. and Wurzler, S.: Heterogeneous drop freezing in the Immersion mode: model calculations considering soluble and insoluble particles in the drops, J. Atmos. Sci., 61, 2063-2072, 2004.

Diehl, K., Quick, C., Matthias-Maser, S., Mitra, S. K., and Jaenicke, R.: The ice nucleating ability of pollen. Part I: Laboratory studies in deposition and condensation freezing modes, Atmos. Res., 58, 75-87, 2001.

Diehl, K., Matthias-Maser, S., Jaenicke, R., and Mitra, S. K.: The ice nucleating ability of pollen. Part II: Laboratory studies in immersion and contact freezing modes., Atmos. Res., 61, 125-133, 2002.

Diehl, K., Simmel, M., and Wurzler, S.: Numerical sensitivity studies on the impact of aerosol properties and drop freezing modes on the glaciation, microphysics, and dynamics of clouds, J. Geophys. Res., 111, D07202, doi:10.1029/2005JD005884, 2006.

Dufour, L.: Über das Gefrieren des Wassers und über die Bildung des Hagels, Bibl. univ. Aer., 1861.

Durant, A. J. and Shaw, R. A.: Evaporation freezing by contact nucleation inside-out, Geophys. Res. Lett., 32, L20814, doi:10.1029/2005GL024175, 2005.

Durant, A. J., Shaw, R. A., Rose, W. I., Mi, Y., and Ernst, G. G. J.: Ice nucleation and overseeding of ice in volcanic clouds, J. Geophys. Res., 113, D09206, doi:10.1029/2007JD009064, 2008.
Dymarska, M., Murray, B. J., Sun, L., Eastwood, M. L., Knopf, D. A., and Bertram, A. K.: Deposition ice nucleation on soot at temperatures relevant for the lower troposphere, J. Geophys. Res., 111, D04204, doi:10.1029/2005JD006627, 2006.

Eastwood, M. L., Cremel, S., Gehrke, C., Girard, E., and Bertram, A. K.: Ice nucleation on mineral dust particles: onset conditions, nucleation rates and contact angles, J. Geophys. Res., 113, D22203, doi:10.1029/2008JD010639, 2008.

Eastwood, M. L., Cremel, S., Wheeler, M., Murray, B. J., Girard, E., and Bertram, A. K.: Effects of sulfuric acid and ammonium sulfate coatings on the ice nucleation properties of kaolinite particles, Geophys. Res. Lett., 36, L02811, doi:10.1029/2008GL035997, 2009.

Eidhammer, T., DeMott, P. J., Prenni, A. J., Petters, M. D., Twohy, C. H., Rogers, D. C., Stith, J., Heymsfield, A., Wang, Z., Pratt, K. A., Prather, K. A., Murphy, S. M., Seinfeld, J. H., Subramanian, R., and Kreidenweis, S. M.: Ice initiation by aerosol particles: measured and predicted ice nuclei concentrations versus measured ice crystal concentrations in an orographic wave cloud, J. Atmos. Sci., 67, 2417-2436, 2010.

Ervens, B., Feingold, G., Sulia, K., and Harrington, J.: The impact of microphysical parameters, ice nucleation mode, and habit growth on the ice/liquid partitioning in mixed-phase Arctic clouds, J. Geophys. Res., 116, D17205, doi:10.1029/2011JD015729, 2011.

Field, P. R., Hogan, R. J., Brown, P. R. A., Illingworth, A. J., Choularton, T. W., Kaye, P. H., Hirst, E., and Greenaway, R.: Simultaneous radar and aircraft observations of mixed-phase cloud at the $100 \mathrm{~m}$ scale, Q. J. Roy. Meteor. Soc., 130, 1877-1904, 2004.

Field, P. R., Möhler, O., Connolly, P., Krämer, M., Cotton, R., Heymsfield, A. J., Saathoff, H., and Schnaiter, M.: Some ice nucleation characteristics of Asian and Saharan desert dust, Atmos. Chem. Phys., 6, 2991-3006, doi:10.5194/acp-6-2991-2006, 2006.

Fletcher, N. H.: Size effect in heterogeneous nucleation, J. Chem. Phys., 29, 572-576, 1958.

Fletcher, N. H.: Physics of Rain Clouds, Cambridge University Press, 386 pp., 1962.

Fornea, A. P., Brooks, S. D., Dooley, J. B., and Saha, A.: Heterogeneous freezing of ice on atmospheric aerosols containing ash, soot, and soil, J. Geophys. Res., 114, D13201, doi:10.1029/2009JD011958, 2009.

Friedman, B., Kulkarni, G., Beránek, J., Zelenyuk, A., Thornton, J., and Cziczo, D.: Ice nucleation and droplet formation by bare and coated soot particles, J. Geophys. Res., 116, D17203, doi:10.1029/2011JD015999, 2011.

Fukuta, N.: Ice nucleation by metaldehyde, Nature, 199, 475-476, doi:10.1038/199475a0, 1963.

Fukuta, N. and Schaller, R. C.: Ice nucleation by aerosol particles: theory of condensation-freezing nucleation, J. Atmos. Sci., 39, 648-655, 1982.

Georgii, H. W. and Kleinjung, E.: Relations between the chemical composition of atmospheric aerosol particles and the concentration of natural ice nuclei, J. Rech. Atmos., 3, 145-156, 1967.

Govindarajan, A. G. and Lindow, S. E.: Size of bacterial icenucleation sites measured in situ by radiation inactivation analysis, Proc. Natl. Acad. Sci. USA, 85, 1334-1338, 1988. 
Gorbunov, B., Baklanov, A., Kakutkina, N., Windsor, H. L., and Toumi, R.: Ice nucleation on soot particles, J. Aerosol Sci., 32, 199-215, 2001.

Gross, D. C., Cody, Y. S., Proebsting Jr., E. L., Radamaker, G. K., and Spotts, R. A.: Distribution, population dynamics, and characteristics of ice nucleation-active bacteria in deciduous fruit tree orchards, Appl. Environ. Microbiol., 46, 1370-1379, 1983.

Grützun, V., Knoth, O., and Simmel, M.: Simulation of the influence of aerosol particle characteristics on clouds and precipitation with LM-SPECS: model description and first results, Atmos. Res., 90, 233-242, 2008.

Haag, W., Kärcher, B., Ström, J., Minikin, A., Lohmann, U., Ovarlez, J., and Stohl, A.: Freezing thresholds and cirrus cloud formation mechanisms inferred from in situ measurements of relative humidity, Atmos. Chem. Phys., 3, 1791-1806, doi:10.5194/acp3-1791-2003, 2003.

Hendricks, J., Kärcher, B., and Lohmann, U.: Effects of ice nuclei on cirrus clouds in a global climate model, J. Geophys. Res., 116, D18206, doi:10.1029/2010JD015302, 2011.

Herich, H., Tritscher, T., Wiacek, A., Gysel, M., Weingartner, E., Lohmann, U., Baltensperger, U., and Cziczo, D. J.: Water uptake of clay and desert dust aerosol particles at sub- and supersaturated water vapor conditions, Phys. Chem. Chem. Phys., 11, 7804-7809, doi:10.1039/b901585j, 2009.

Hirano, S. S. and Upper, C. D.: Ecology of ice nucleation-active bacteria, in: Biological Ice Nucleation and its Applications, edited by: Lee, R. E., Warren, G. J., and Gusta, L. V., The American Phytopathological Society, St. Paul, Minnesota, USA, 41-61, 1995.

Hirano, S. S., Baker, L., and Upper, C. D.: Ice nucleation temperature of individual leaves in relation to population sizes of ice nucleation active bacteria and frost injury, Plant Physiol., 77, 259265, 1985.

Hoffer, T. E.: A laboratory investigation of droplet freezing, J. Meteorol., 18, 766-778, 1961.

Hoose, C., Lohmann, U., Erdin, R., and Tegen, I.: Global influence of dust mineralogical composition on heterogeneous ice nucleation in mixed-phase clouds, Environ. Res. Lett., 3, 025003, doi:10.1088/1748-9326/3/2/025003, 2008.

Hoose, C., Kristjánsson, J. E., and Burrows, S. M.: How important is biological ice nucleation in clouds on a global scale?, Environ. Res. Lett., 5, 024009, doi:10.1088/1748-9326/5/2/024009, 2010a.

Hoose, C., Kristjánsson, J. E., Chen, J.-P., and Hazra, A.: A classical-theory-based parameterization of heterogeneous ice nucleation by mineral dust, soot and biological particles in a global climate model, J. Atmos. Sci., 67, 2483-2503, doi:10.1175/2010JAS3425.1, 2010b.

Hoyle, C. R., Pinti, V., Welti, A., Zobrist, B., Marcolli, C., Luo, B., Höskuldsson, Á., Mattsson, H. B., Stetzer, O., Thorsteinsson, T., Larsen, G., and Peter, T.: Ice nucleation properties of volcanic ash from Eyjafjallajökull, Atmos. Chem. Phys., 11, 9911-9926, doi:10.5194/acp-11-9911-2011, 2011.

Hung, H., Malinowski, A., and Martin, S. T.: Ice nucleation kinetics of aerosols containing aqueous and solid ammonium sulfate particles, J. Phys. Chem. A, 106, 293-306, 2002.

Hung, H., Malinowski, A., and Martin, S. T.: Kinetics of heterogeneous ice nucleation on the surfaces of mineral dust cores inserted into aqueous ammonium sulfate particles, J. Phys. Chem.
A, 107, 1296-1306, 2003.

Iannone, R., Chernoff, D. I., Pringle, A., Martin, S. T., and Bertram, A. K.: The ice nucleation ability of one of the most abundant types of fungal spores found in the atmosphere, Atmos. Chem. Phys., 11, 1191-1201, doi:10.5194/acp-11-11912011, 2011.

Iraci, L. T., Phebus, B. D., Stone, B. M., and Colaprete, A.: Water ice cloud formation on Mars is more difficult than presumed: Laboratory studies of ice nucleation on surrogate materials, Icarus, 210, 985-991, doi:10.1016/j.icarus.2010.07.020, 2010.

Isono, K. and Ibeke, Y.: On the ice-nucleating ability of rockforming minerals and soil particles, J. Meteorol. Soc. Jpn., 38, 213-230, 1960.

Isono, K., Komabayashi, M., and Ono, A.: The nature and the origin of ice nuclei in the atmosphere, J. Meteorol. Soc. Jpn., 37, 195199, 1959a.

Isono, K., Komabayashi, M., and Ono, A.: Volcanoes as a source of atmospheric ice nuclei, Nature, 31, 317-318, $1959 \mathrm{~b}$.

Jayaweera, K. and Flanagan, P.: Investigations on biogenic ice nuclei in the Arctic atmosphere., Geophys. Res. Lett., 9, 94-97, 1982.

Jones, H. M., Flynn, M. J., DeMott, P. J., and Möhler, O.: Manchester Ice Nucleus Counter (MINC) measurements from the 2007 International workshop on Comparing Ice nucleation Measuring Systems (ICIS-2007), Atmos. Chem. Phys., 11, 53-65, doi:10.5194/acp-11-53-2011, 2011.

Junge, K. and Swanson, B. D.: High-resolution ice nucleation spectra of sea-ice bacteria: implications for cloud formation and life in frozen environments, Biogeosciences, 5, 865-873, doi:10.5194/bg-5-865-2008, 2008.

Kajava, A. V. and Lindow, S. E.: A Model of the Three-dimensional Structure of Ice Nucleation Proteins, Journal of Molecular Biology, 232, 709-717, 1993.

Kanitz, T., Seifert, P., Ansmann, A., Engelmann, R., Althausen, D., Casiccia, C., and Rohwer, E. G.: Contrasting the impact of aerosols at northern and southern midlatitudes on heterogeneous ice formation, Geophys. Res. Lett., 38, L17802, doi:10.1029/2011GL048532, 2011.

Kanji, Z. A. and Abbatt, J. P. D.: Laboratory studies of ice formation via deposition mode nucleation onto mineral dust and n-hexane soot samples, J. Geophys. Res., 111, D16204, doi:10.1029/2005JD006766, 2006.

Kanji, Z. A. and Abbatt, J. P. D.: Ice nucleation onto Arizona test dust at cirrus temperatures: effect of temperature and aerosol size on onset relative humidity, J. Phys. Chem. A, 114, 935-941, 2010.

Kanji, Z. A., Florea, O., and Abbatt, J. P. D.: Ice formation via deposition nucleation on mineral dust and organics: dependence of onset relative humidity on total particulate surface area, Environ. Res. Lett., 3, 025004, doi:10.1088/1748-9326/3/2/025004, 2008.

Kanji, Z. A., DeMott, P. J., Möhler, O., and Abbatt, J. P. D.: Results from the University of Toronto continuous flow diffusion chamber at ICIS 2007: instrument intercomparison and ice onsets for different aerosol types, Atmos. Chem. Phys., 11, 31-41, doi:10.5194/acp-11-31-2011, 2011.

Kärcher, B. and Lohmann, U.: A parameterization of cirrus cloud formation: heterogeneous freezing, J. Geophys. Res., 108, 4402, doi:10.1029/2002JD003220, 2003. 
Kärcher, B., Möhler, O., DeMott, P. J., Pechtl, S., and Yu, F.: Insights into the role of soot aerosols in cirrus cloud formation, Atmos. Chem. Phys., 7, 4203-4227, doi:10.5194/acp-7-4203-2007, 2007.

Kelly, J. T., Chuang, C. C., and Wexler, A. S.: Influence of dust composition on cloud droplet formation, Atmos. Environ., 41, 2904-2916, 2007.

Khvorostyanov, V. and Sassen, K.: Toward the theory of homogeneous nucleation and its parameterization for cloud models, Geophys. Res. Lett., 25, 3155-3158, 1998.

Khvorostyanov, V. I. and Curry, J. A.: The Theory of Ice Nucleation by Heterogeneous Freezing of Deliquescent Mixed CCN. Part I: Critical Radius, Energy, and Nucleation Rate, J. Atmos. Sci., 61, 2676-2691, 2004.

Khvorostyanov, V. I. and Curry, J. A.: The theory of ice nucleation by heterogeneous freezing of deliquescent mixed CCN. Part II: Parcel model simulation, J. Atmos. Sci., 62, 261-285, 2005.

Kireeva, E. D., Popovicheva, O. B., Persiantseva, N. M., Khokhlova, T. D., and Shonija, N. K.: Effect of black carbon particles on the efficiency of water droplet freezing, Colloid J., 71, 353-359, 2009.

Knopf, D. A. and Koop, T.: Heterogeneous nucleation of ice on surrogates of mineral dust, J. Geophys. Res., 111, D12201, doi:10.1029/2005JD006894, 2006.

Knopf, D. A., Wang, B., Laskin, A., Moffet, R. C., and Gilles, M. K.: Heterogeneous nucleation of ice on anthropogenic organic particles collected in Mexico City, Geophys. Res. Lett., 37, L11803, doi:10.1029/2010GL043362, 2010.

Knopf, D. A., Alpert, P. A., Wang, B., and Aller, J. Y.: Stimulation of ice nucleation by marine diatoms, Nature Geoscience, 4, 8890, doi:10.1038/ngeo1037, 2011.

Koehler, K. A., Kreidenweis, S. M., DeMott, P. J., Prenni, A. J., and Petters, M. D.: Potential impact of Owens (dry) Lake dust on warm and cold cloud formation, J. Geophys. Res., 112, D12210, doi:10.1029/2007JD008413, 2007.

Koehler, K. A., DeMott, P. J., Kreidenweis, S. M., Popovicheva, O. B., Petters, M. D., Carrico, C. M., Kireeva, E. D., Khokhlovac, T. D., and Shonijac, N. K.: Cloud condensation nuclei and ice nucleation activity of hydrophobic and hydrophilic soot particles, Phys. Chem. Chem. Phys., 11, 7906-7920, doi:10.1039/b905334b, 2009.

Koehler, K. A., Kreidenweis, S. M., DeMott, P. J., Petters, M. D., Prenni, A. J., and Möhler, O.: Laboratory investigations of the impact of mineral dust aerosol on cold cloud formation, Atmos. Chem. Phys., 10, 11955-11968, doi:10.5194/acp-1011955-2010, 2010.

Koop, T. and Zobrist, B.: Parameterizations for ice nucleation in biological and atmospheric systems, Phys. Chem. Chem. Phys., 11, 10839-10850, doi:10.1039/b914289d, 2009.

Koop, T., Luo, B., Tsias, A., and Peter, T.: Water activity as the determinant for homogeneous ice nucleation in aqueous solutions, Nature, 406, 611-614, 2000.

Korolev, A. V., Isaac, G. A., Cober, S. G., Strapp, J. W., and Hallett, J.: Microphysical characterization of mixed-phase clouds, Q. J. Roy. Meteor. Soc., 129, 39-65, 2003.

Kämer, M., Schiller, C., Afchine, A., Bauer, R., Gensch, I., Mangold, A., Schlicht, S., Spelten, N., Sitnikov, N., Borrmann, S., de Reus, M., and Spichtinger, P.: Ice supersaturations and cirrus cloud crystal numbers, Atmos. Chem. Phys., 9, 3505-3522, doi:10.5194/acp-9-3505-2009, 2009.

Kulkarni, G. and Dobbie, S.: Ice nucleation properties of mineral dust particles: determination of onset $\mathrm{RH}_{i}$, IN active fraction, nucleation time-lag, and the effect of active sites on contact angles, Atmos. Chem. Phys., 10, 95-105, doi:10.5194/acp-10-95-2010, 2010.

Kulkarni, G., Dobbie, S., and McQuaid, J. B.: A new thermal gradient ice nucleation diffusion chamber instrument: design, development and first results using Saharan mineral dust, Atmos. Meas. Tech., 2, 221-229, doi:10.5194/amt-2-221-2009, 2009.

Kulkarni, G., Fan, J., Comstock, J. M., Liu, X., and Ovchinnikov, M.: Laboratory measurements and model sensitivity studies of dust deposition ice nucleation, Atmos. Chem. Phys., 12, 7295-7308, 10.5194/acp-12-7295-2012, 2012.

Ladino, L., Stetzer, O., Lüönd, F., Welti, A., and Lohmann, U.: Contact freezing experiments of kaolinite particles with cloud droplets, J. Geophys. Res., 116, D22202, doi:10.1029/2011JD015727, 2011.

Lagriffoul, A., Boudenne, J. L., Absi, R., Ballet, J. J., Berjeaud, J. M., Chevalier, S., Creppy, E., Gilli, E., Gadonna, J. P., Gadonna-Widehem, P., Morris, C. E., , and Zini, S.: Bacterialbased additives for the production of artificial snow: What are the risks to human health?, Science of the Total Environment, 408, 1659-1666, 2010.

Langer, G.: Analysis of results from second international ice nucleus workshop with emphasis on expansion chambers, NCAR counters, and membrane filters, J. Appl. Meteorol., 12, 991-999, doi:10.1175/1520-0450(1973)012<0991:AORFSI > 2.0.CO;2, 1973.

Levin, Z. and Yankofsky, S. A.: Contact versus immersion freezing of freely suspended droplets by bacterial ice nuclei, J. Clim. Appl. Meteorol., 22, 1964-1966, 1983.

Lindemann, J., Constantinidou, H. A., Barchet, W. R., and Upper, C. D.: Plants as sources of airborne bacteria, including ice nucleation-active bacteria, Appl. Environ. Microb., 44, 10591063, 1982.

Lindow, S. E., Lahue, E., Govindarajan, A. G., Panopoulos, N. J., and Gies, D.: Localization of ice nucleation activity and the ice C gene product in Pseudomonas syringae and Escherichia coli, Mol. Plant Microbe In., 2, 262-272, 1989.

Liu, X. and Penner, J. E.: Ice nucleation parameterization for global models, Meteorol. Z., 14, 499-514, 2005.

Lohmann, U. and Diehl, K.: Sensitivity studies of the importance of dust ice nuclei for the indirect aerosol effect on stratiform mixedphase clouds, J. Atmos. Sci., 63, 968-982, 2006.

Lüönd, F., Stetzer, O., Welti, A., and Lohmann, U.: Experimental study on the ice nucleation ability of size selected kaolinite particles in the immersion mode, J. Geophys. Res., 115, D14201, doi:10.1029/2009JD012959, 2010.

Maki, L. R. and Willoughby, K. J.: Bacteria as biogenic sources of freezing nuclei, J. Appl. Meteorol., 17, 1049-1053, 1978.

Maki, L. R., Galyan, E. L., Chang-Chien, M.-M., and Caldwell, D. R.: Ice nucleation induced by Pseudomonas syringae, Appl. Microbiol., 28, 456-459, 1974.

Mangold, A., Wagner, R., Saathoff, H., Schurath, U., Giesemann, C., Ebert, V., Krämer, M., and Möhler, O.: Experimental investigation of ice nucleation by different types of aerosols in the aerosol chamber AIDA: implications to microphysics of cirrus clouds, Meteorol. Z., 14, 485-497, 2005. 
Marcolli, C., Gedamke, S., Peter, T., and Zobrist, B.: Efficiency of immersion mode ice nucleation on surrogates of mineral dust, Atmos. Chem. Phys., 7, 5081-5091, doi:10.5194/acp-7-50812007, 2007.

Mason, B. J.: Ice-nucleating properties of clay minerals and stony meteorites, Q. J. Roy. Meteor. Soc., 86, 552-556, 1960.

Mason, B. J.: The Physics of Clouds, Oxford University Press, 688 pp., 1971.

Mason, B. J. and Maybank, J.: Ice-nucleating properties of some natural mineral dusts, Q. J. Roy. Meteor. Soc., 84, 235-241, 1958.

Meyers, M. P., DeMott, P. J., and Cotton, W. R.: New primary icenucleation parameterizations in an explicit cloud model, J. Appl. Meteorol., 31, 708-721, 1992.

Möhler, O., Büttner, S., Linke, C., Schnaiter, M., Saathoff, H., Stetzer, O., Wagner, R., Krämer, M., Mangold, A., Ebert, V., and Schurath, U.: Effect of sulfuric acid coating on heterogeneous ice nucleation by soot aerosol particles, J. Geophys. Res., 110, D11210, doi:10.1029/2004JD005169, 2005a.

Möhler, O., Linke, C., Saathoff, H., Schnaiter, M., Wagner, R., Mangold, A., Krämer, M., and Schurath, U.: Ice nucleation on flame soot aerosol of different organic carbon content, Meteorol. Z., 14, 477-484, 2005b.

Möhler, O., Field, P. R., Connolly, P., Benz, S., Saathoff, H., Schnaiter, M., Wagner, R., Cotton, R., Krämer, M., Mangold, A., and Heymsfield, A. J.: Efficiency of the deposition mode ice nucleation on mineral dust particles, Atmos. Chem. Phys., 6, 30073021, doi:10.5194/acp-6-3007-2006, 2006.

Möhler, O., Benz, S., Saathoff, H., Schnaiter, M., Wagner, R., Schneider, J., Walter, S., Ebert, V., and Wagner, S.: The effect of organic coating on the heterogeneous ice nucleation efficiency of mineral dust aerosols, Environ. Res. Lett., 3, 025007 , doi:10.1088/1748-9326/3/2/025007, 2008a.

Möhler, O., Georgakopoulos, D. G., Morris, C. E., Benz, S., Ebert, V., Hunsmann, S., Saathoff, H., Schnaiter, M., and Wagner, R.: Heterogeneous ice nucleation activity of bacteria: new laboratory experiments at simulated cloud conditions, Biogeosciences, 5, 1425-1435, doi:10.5194/bg-5-1425-2008, 2008b.

Moll, W. F.: The Origin and Development of the Source Clays Program,

http://www.agry.purdue.edu/cjohnston/sourceclays/ scr_history.htm, last access: 13 September 2012, 2002.

Morris, C. E., Sands, D. C., Vinatzer, B., Glaux, C., Guilbaud, C., Buffière, A., Yan, S., Dominguez, H., and Thompson, B. M.: The life history of the plant pathogen Pseudomonas syringae is linked to the water cycle, ISME J., 2, 321-334, 2008.

Mortazavi, R., Hayes, C. T., and Ariya, P. A.: Ice nucleation activity of bacteria isolated from snow compared with organic and inorganic substrates, Environ. Chem., 5, 373-381, 2008.

Murphy, D. M. and Koop, T.: Review of the vapour pressures of ice and supercooled water for atmospheric applications, Q. J. Roy. Meteor. Soc., 131, 1539-1565, 2005.

Murray, B. J., Wilson, T. W., Dobbie, S., Cui, Z., AlJumur, S. M. R. K., Möhler, O., Schnaiter, M., Wagner, R., Benz, S., Niemand, M., Saathoff, H., Ebert, V., Wagner, S., and Kärcher, B.: Heterogeneous nucleation of ice particles on glassy aerosols under cirrus conditions, Nat. Geosci., 3, 233-237, doi:10.1038/ngeo817, 2010.
Murray, B. J., Wilson, T. W., Broadley, S. L., and Wills, R. H.: Heterogeneous freezing of water droplets containing kaolinite and montmorillonite particles, Atmos. Chem. Phys. Discuss., 10, 9695-9729, doi:10.5194/acpd-10-9695-2010, 2010.

Murray, B. J., Broadley, S. L., Wilson, T. W., Atkinson, J. D., and Wills, R. H.: Heterogeneous freezing of water droplets containing kaolinite particles, Atmos. Chem. Phys., 11, 4191-4207, doi:10.5194/acp-11-4191-2011, 2011.

Niedermeier, D., Hartmann, S., Shaw, R. A., Covert, D., Mentel, T. F., Schneider, J., Poulain, L., Reitz, P., Spindler, C., Clauss, T., Kiselev, A., Hallbauer, E., Wex, H., Mildenberger, K., and Stratmann, F.: Heterogeneous freezing of droplets with immersed mineral dust particles - measurements and parameterization, Atmos. Chem. Phys., 10, 3601-3614, doi:10.5194/acp-103601-2010, 2010.

Niedermeier, D., Hartmann, S., Clauss, T., Wex, H., Kiselev, A., Sullivan, R. C., DeMott, P. J., Petters, M. D., Reitz, P., Schneider, J., Mikhailov, E., Sierau, B., Stetzer, O., Reimann, B., Bundke, U., Shaw, R. A., Buchholz, A., Mentel, T. F., and Stratmann, F.: Experimental study of the role of physicochemical surface processing on the IN ability of mineral dust particles, Atmos. Chem. Phys., 11, 11131-11144, doi:10.5194/acp11-11131-2011, 2011a.

Niedermeier, D., Shaw, R. A., Hartmann, S., Wex, H., Clauss, T., Voigtländer, J., and Stratmann, F.: Heterogeneous ice nucleation: exploring the transition from stochastic to singular freezing behavior, Atmos. Chem. Phys., 11, 8767-8775, doi:10.5194/acp11-8767-2011, 2011b.

Niemand, M., Möhler, O., Vogel, B., Vogel, H., Hoose, C., Connolly, P., Klein, H., Bingemer, H., Skrotzki, J., and Leisner, T.: A particle-surface-area-based parameterization of immersion freezing on mineral dust particles, J. Atmos. Sci., doi:10.1175/JAS-D11-0249.1, in press, 2012.

Obata, H., Muryoi, N., Kawahara, H., Yamade, K., and Nishikawa, J.: Identification of a novel ice-nucleating bacterium of Antarctic origin and its ice nucleation properties, Cryobiology, 38, 131-139, 1999.

Peter, T., Marcolli, C., Spichtinger, P., Corti, T., Baker, M., and Koop, T.: When dry air is too humid, Science, 314, 1399-1402, doi:10.1126/science.1135199, 2006.

Petters, M. D., Parsons, M. T., Prenni, A. J., DeMott, P. J., Kreidenweis, S. M., Carrico, C. M., Sullivan, A. P., McMeeking, G. R., Levin, E., Wold, C. E., Collett Jr., J. L., and Moosmüller, H.: Ice nuclei emissions from biomass burning, J. Geophys. Res., 114, L06808, doi:10.1029/2008JD011532, 2009.

Phillips, V. T. J., DeMott, P. J., and Andronache, C.: An empirical parameterization of heterogeneous ice nucleation for multiple chemical species of aerosol, J. Atmos. Sci., 65, 2757-2783, 2008.

Phillips, V. T. J., Andronache, C., Christner, B., Morris, C. E., Sands, D. C., Bansemer, A., Lauer, A., McNaughton, C., and Seman, C.: Potential impacts from biological aerosols on ensembles of continental clouds simulated numerically, Biogeosciences, 6 , 987-1014, doi:10.5194/bg-6-987-2009, 2009.

Pinti, V., Marcolli, C., Zobrist, B., Hoyle, C. R., and Peter, T.: Ice nucleation efficiency of clay minerals in the immersion mode, Atmos. Chem. Phys., 12, 5859-5878, doi:10.5194/acp-12-58592012, 2012. 
Pitter, R. L. and Pruppacher, H. R.: A wind tunnel investigation of freezing of small water drops falling at terminal velocity in air, Q. J. Roy. Meteor. Soc., 99, 540-550, 1973.

Popovicheva, O., Kireeva, E., Persiantseva, N., Khokhlova, T., Shonija, N., Tishkova, V., and Demirdjian, B.: Effect of soot on immersion freezing of water and possible atmospheric implications, Atmos. Res., 90, 326-337, 2008.

Pouleur, S., Richard, C., Martin, J.-G., and Antoun, H.: Ice nucleation activity in Fusarium acuminatum and Fusarium avenaceum, Appl. Environ. Microb., 58, 2960-2964, 1992.

Prenni, A. J., DeMott, P. J., Kreidenweis, S. M., Sherman, D. E., Russell, L. M., and Ming, Y.: The effects of low molecular weight dicarboxylic acids on cloud formation, J. Phys. Chem. A, 105, 11240-11248, doi:10.1021/jp012427d, 2001.

Prenni, A. J., Petters, M. D., Faulhaber, A., Carriço, C. M., Ziemann, P. J., Kreidenweis, S. M., and DeMott, P. J.: Heterogeneous ice nucleation measurements of secondary organic aerosol generated from ozonolysis of alkenes, Geophys. Res. Lett., 36, D21303, doi:10.1029/2008GL036957, 2009.

Pruppacher, H. R. and Klett, J. D.: Microphysics of Clouds and Precipitation, Atmospheric and Oceanographic Sciences Library, Kluwer Academic Publishers, Dordrecht, The Netherlands, 1997.

Pruppacher, H. R. and Saenger, R.: Mechanismus der Vereisung unterkühlter Wassertropfen durch disperse Keimsubstanzen, Z. Angew. Math. Phys., 6, 407-416, doi:10.1007/BF01589767, 1955.

Pummer, B. G., Bauer, H., Bernardi, J., Bleicher, S., and Grothe, H.: Suspendable macromolecules are responsible for ice nucleation activity of birch and conifer pollen, Atmos. Chem. Phys., 12, 2541-2550, doi:10.5194/acp-12-2541-2012, 2012.

Reitz, P., Spindler, C., Mentel, T. F., Poulain, L., Wex, H., Mildenberger, K., Niedermeier, D., Hartmann, S., Clauss, T., Stratmann, F., Sullivan, R. C., DeMott, P. J., Petters, M. D., Sierau, B., and Schneider, J.: Surface modification of mineral dust particles by sulphuric acid processing: implications for ice nucleation abilities, Atmos. Chem. Phys., 11, 7839-7858, doi:10.5194/acp-117839-2011, 2011.

Roberts, P. and Hallett, J.: A laboratory study of the ice nucleating properties of some mineral particulates, Q. J. Roy. Meteor. Soc., 94, 25-34, 1968.

Rzesanke, D., Duft, D., and Leisner, T.: Laboratory experiments on the microphysics of electrified cloud droplets, in: Climate And Weather of the Sun-Earth System (CAWSES): Highlights from a priority program, edited by Lübken, F.-J., Springer, Dordrecht, The Netherlands, 2011.

Salam, A., Lohmann, U., Crenna, B., Lesins, G., Klages, P., Rogers, D., Irani, R., MacGillivray, A., and Coffin, M.: Ice nucleation studies of mineral dust particles with a new continuous flow diffusion chamber, Aerosol Sci. Tech., 40, 134-143, 2006.

Salam, A., Lohmann, U., and Lesins, G.: Ice nucleation of ammonia gas exposed montmorillonite mineral dust particles, Atmos. Chem. Phys., 7, 3923-3931, doi:10.5194/acp-7-3923-2007, 2007.

Sands, D. C., Langhans, V. E., Scharen, A. L., and de Smet, G.: The association between bacteria and rain and possible resultant meteorological implications, Időjárás, 86, 148-152, 1982.

Schaefer, V. J.: The formation of ice crystals in the laboratory and the atmosphere, Chem. Rev., 44, 291-320, 1949.
Schaller, R. and Fukuta, N.: Ice nucleation by aerosol-particles experimental studies using a wedge-shaped ice thermal-diffusion chamber, J. Atmos. Sci., 36, 1788-1802, 1979.

Schuttlefield, J. D., Cox, D., and Grassian, V. H.: An investigation of water uptake on clays minerals using ATR-FTIR spectroscopy coupled with quartz crystal microbalance measurements, J. Geophys. Res., 112, D20201, doi:10.1029/2007JD008973, 2007.

Seifert, P., Ansmann, A., Mattis, I., Wandinger, U., Tesche, M., Engelmann, R., Müller, D., Pérez, C., and Haustein, K.: Saharan dust and heterogeneous ice formation: Eleven years of cloud observations at a central European EARLINET site, J. Geophys. Res., 115, D12204, doi:10.1029/2009JD013222, 2010.

Seisel, S., Pashkova, A., Lian, Y., and Zellner, R.: Water uptake on mineral dust and soot: A fundamental view of the hydrophilicity of atmospheric particles?, Faraday Discuss., 130, 437-451, doi:10.1039/b417449f, 2005.

Shilling, J. E., Fortin, T. J., and Tolbert, M. A.: Depositional ice nucleation on crystalline organic and inorganic solids, J. Geophys. Res., 111, D05207, doi:10.1029/2005JD006664, 2006.

Spichtinger, P. and Gierens, K. M.: Modelling of cirrus clouds - Part 2: Competition of different nucleation mechanisms, Atmos. Chem. Phys., 9, 2319-2334, doi:10.5194/acp-9-2319-2009, 2009.

Steinke, I., Möhler, O., Kiselev, A., Niemand, M., Saathoff, H., Schnaiter, M., Skrotzki, J., Hoose, C., and Leisner, T.: Ice nucleation properties of fine ash particles from the Eyjafjallajökull eruption in April 2010, Atmos. Chem. Phys., 11, 12945-12958, doi:10.5194/acp-11-12945-2011, 2011.

Storelvmo, T., Kristjánsson, J. E., and Lohmann, U.: Aerosol influence on mixed-phase clouds in CAM-Oslo, J. Atmos. Sci., 65, 3214-3230, 2008.

Storelvmo, T., Hoose, C., and Eriksson, P.: Global modeling of mixed-phase clouds: The albedo and lifetime effects of aerosols, J. Geophys. Res., 116, D03205, doi:10.1029/2010JD014724, 2011.

Sullivan, R. C., Miñambres, L., DeMott, P. J., Prenni, A. J., Carrico, C. M., Levin, E. J. T., and Kreidenweis, S. M.: Chemical processing does not always impair heterogeneous ice nucleation of mineral dust particles, Geophys. Res. Lett., 37, L24805, doi:10.1029/2010GL045540, 2010a.

Sullivan, R. C., Petters, M. D., DeMott, P. J., Kreidenweis, S. M., Wex, H., Niedermeier, D., Hartmann, S., Clauss, T., Stratmann, F., Reitz, P., Schneider, J., and Sierau, B.: Irreversible loss of ice nucleation active sites in mineral dust particles caused by sulphuric acid condensation, Atmos. Chem. Phys., 10, 1147111487, doi:10.5194/acp-10-11471-2010, 2010b.

Suzanne, J., Ferry, D., Popovitcheva, O., and Shonija, N. K.: Ice nucleation by kerosene soot under upper tropospheric conditions, Can. J. Phys., 81, 423-429, 2003.

Svensson, E. A., Delval, C., von Hessberg, P., Johnson, M. S., and Pettersson, J. B. C.: Freezing of water droplets colliding with kaolinite particles, Atmos. Chem. Phys., 9, 4295-4300, doi:10.5194/acp-9-4295-2009, 2009.

Tishkova, V., Demirdjian, B., Ferry, D., and Johnson, M.: Neutron diffraction study of water freezing on aircraft engine combustor soot, Phys. Chem. Chem. Phys., 13, 20729-20735, 2011.

Vali, G.: Quantitative evaluation of experimental results on the heterogeneous freezing nucleation of supercooled liquids, J. Atmos. Sci., 28, 402-409, 1971. 
Vali, G.: Freezing rate due to heterogeneous nucleation, J. Atmos. Sci., 51, 1843-1856, 1994.

Vali, G.: Repeatability and randomness in heterogeneous freezing nucleation, Atmos. Chem. Phys., 8, 5017-5031, doi:10.5194/acp-8-5017-2008, 2008.

Vali, G., Christensen, M., Fresh, R. W., Galyan, E. L., Maki, L. R., and Schnell, R. C.: Biogenic ice nuclei. Part II: Bacterial sources, J. Atmos. Sci., 33, 1565-1570, 1976.

Vali, G. and Stansbury, E. J.: Time-dependent characteristics of the heterogeneous nucleation of ice, Can. J. Phys., 44, 477-502, 1966.

von Blohn, N., Mitra, S. K., Diehl, K., and Borrmann, S.: The ice nucleating ability of pollen. Part III: New laboratory studies in immersion and contact freezing modes including more pollen types, Atmos. Res., 78, 182-189, 2005.

Vonnegut, B.: The nucleation of ice formation by silver iodide, J. Appl. Phys., 18, 593-595, doi:10.1063/1.1697813, 1947.

Wagner, R., Möhler, O., Saathoff, H., Schnaiter, M., and Leisner, T.: High variability of the heterogeneous ice nucleation potential of oxalic acid dihydrate and sodium oxalate, Atmos. Chem. Phys., 10, 7617-7641, doi:10.5194/acp-10-7617-2010, 2010.

Wagner, R., Möhler, O., Saathoff, H., Schnaiter, M., and Leisner, T.: New cloud chamber experiments on the heterogeneous ice nucleation ability of oxalic acid in the immersion mode, Atmos. Chem. Phys., 11, 2083-2110, doi:10.5194/acp-11-2083-2011, 2011.

Wagner, R. and Möhler, O. and Saathoff, H. and Schnaiter, M. and Skrotzki, J. and Leisner, T. and Wilson, T. W. and Malkin, T. L. and Murray, B. J.: Ice cloud processing of ultra-viscous/glassy aerosol particles leads to enhanced ice nucleation ability, Atmos. Chem. Phys., 12, 8589-8610, doi:10.5194/acp-12-85892012, 2012.

Wang, B. and Knopf, D.: Heterogeneous ice nucleation on particles composed of humic-like substances impacted by $\mathrm{O}_{3}$, J. Geophys. Res., 116, D03205, doi:10.1029/2010JD014964, 2011.

Ward, P. and DeMott, P.: Preliminary experimental evaluation of Snomax ${ }^{\mathrm{TM}}$ snow inducer, Pseudomonas syringae, as an artificial ice nucleus for use in weather modification, J. Weather Mod., 21, 9-13, 1989.

Welti, A., Lüönd, F., Stetzer, O., and Lohmann, U.: Influence of particle size on the ice nucleating ability of mineral dusts, Atmos. Chem. Phys., 9, 6705-6715, doi:10.5194/acp-9-6705-2009, 2009.

Welti, A., Lüönd, F., Kanji, Z. A., Stetzer, O., and Lohmann, U.: Time dependence of immersion freezing, Atmos. Chem. Phys. Discuss., 12, 12623-12662, doi:10.5194/acpd-12-12623-2012, 2012.

Wheeler, M. J. and Bertram, A. K.: Deposition nucleation on mineral dust particles: a case against classical nucleation theory with the assumption of a single contact angle, Atmos. Chem. Phys., 12, 1189-1201, doi:10.5194/acp-12-1189-2012, 2012.

Wiacek, A. and Peter, T.: On the availability of uncoated mineral dust ice nuclei in cold cloud regions, Geophys. Res. Lett., 36, doi:10.1029/2009GL039429, 2009.

Wilson, T. W. and Murray, B. J. and Wagner, R. and Möhler, O. and Saathoff, H. and Schnaiter, M. and Skrotzki, J. and Price, H. C. and Malkin, T. L. and Dobbie, S. and Al-Jumur, S. M. R. K.: Glassy aerosols with a range of compositions nucleate ice heterogeneously at cirrus temperatures, Atmos. Chem. Phys., 12, 8611-8632, doi:10.5194/10.5194/acp-12-8611-2012, 2012.
Wise, M. E., Baustian, K. J., and Tolbert, M. A.: Laboratory studies of ice formation pathways from ammonium sulfate particles, Atmos. Chem. Phys., 9, 1639-1646, doi:10.5194/acp-9-1639-2009, 2009.

Wise, M. E., Baustian, K. J., and Tolbert, M. A.: Internally mixed sulfate and organic particles as potential ice nuclei in the tropical tropopause region, P. Natl. Acad. Sci. USA, 107, 6693-6698, 2010.

Wise, M. E., Baustian, K. J., Koop, T., Freedman, M. A., Jensen, E. J., and Tolbert, M. A.: Depositional ice nucleation onto crystalline hydrated $\mathrm{NaCl}$ particles: a new mechanism for ice formation in the troposphere, Atmos. Chem. Phys., 12, 1121-1134, doi:10.5194/acp-12-1121-2012, 2012.

Wood, S. E., Baker, M. B., and Swanson, B. D.: Instrument for studies of homogeneous and heterogeneous ice nucleation in freefalling supercooled water droplets, Rev. Sci. Instrum., 73, 39883996, 2002.

Worland, M. R. and Block, W.: Ice-nucleating bacteria from the guts of two sub-Antarctic beetles Hydromedion sparsutum and Perimylops antarcticus (Perimylopidae), Cryobiology, 38, 6067, 1999.

Yankofsky, S. A., Levin, Z., Bertold, T., and Sandlerman, N.: Some basic characteristics of bacterial freezing nuclei, J. Appl. Meteorol., 20, 1013-1019, 1981.

Young, K. C.: A numerical simulation of wintertime, orographic precipitation: Part I. Description of model microphysics and numerical techniques, J. Atmos. Sci., 31, 1735-1748, 1974.

Zimmermann, F., Weinbruch, S., Schütz, L., Hofmann, H., Ebert, M., Kandler, K., and Worringen, A.: Ice nucleation properties of the most abundant mineral dust phases, J. Geophys. Res., 113, D23204, doi:10.1029/2008JD010655, 2008.

Zobrist, B., Marcolli, C., Koop, T., Luo, B. P., Murphy, D. M., Lohmann, U., Zardini, A. A., Krieger, U. K., Corti, T., Cziczo, D. J., Fueglistaler, S., Hudson, P. K., Thomson, D. S., and Peter, T.: Oxalic acid as a heterogeneous ice nucleus in the upper troposphere and its indirect aerosol effect, Atmos. Chem. Phys., 6, 3115-3129, doi:10.5194/acp-6-3115-2006, 2006.

Zobrist, B., Koop, T., Luo, B. P., Marcolli, C., and Peter, T.: Heterogeneous ice nucleation rate coefficient of water droplets coated by a nonadecanol monolayer, J. Phys. Chem. C, 111, 2149-2155, doi:10.1021/jp066080w, 2007.

Zobrist, B., Marcolli, C., Peter, T., and Koop, T.: Heterogeneous ice nucleation in aqueous solutions: the role of water activity, J. Phys. Chem. A, 112, 3965-3975, doi:10.1021/jp7112208, 2008.

Zuberi, B., Bertram, A. K., Koop, T., Molina, L. T., and Molina, M. J.: Heterogeneous freezing of aqueous particles induced by crystallized $\left(\mathrm{NH}_{4}\right)_{2} \mathrm{SO}_{4}$, ice, and letovicite, J. Phys. Chem. A, 105, 6458-6464, 2001.

Zuberi, B., Bertram, A. K., Cassa, C. A., Molina, L. T., and Molina, M. J.: Heterogeneous nucleation of ice in $\left(\mathrm{NH}_{4}\right)_{2} \mathrm{SO}_{4}-\mathrm{H}_{2} \mathrm{O}$ particles with mineral dust immersions, Geophys. Res. Lett., 29, 1504, doi:10.1029/2001GL014289, 2002. 